\title{
Bili-Uéré: A Chimpanzee Behavioural Realm in Northern Democratic Republic of Congo
}

\author{
Thurston C. Hicks ${ }^{a, b}$ Hjalmar S. Kühl ${ }^{b, c}$ Christophe Boesch ${ }^{b}$ \\ Paula Dieguez $^{\text {b }}$ Ayuk Emmanuel Ayimisin ${ }^{b}$ \\ Rumen Martin Fernande ${ }^{b}$ Donatienne Barubiyo Zungawa ${ }^{b}$ \\ Mbangi Kambere $^{b}$ Jeroen Swinkels ${ }^{d}$ Steph B.J. Menken ${ }^{e}$ \\ John Hart ${ }^{f}$ Roger Mundry ${ }^{b}$ Peter Roessingh ${ }^{e}$ \\ ${ }^{a}$ Faculty of Artes Liberales, University of Warsaw, Warsaw, Poland; ${ }^{b}$ Max Planck Institute for \\ Evolutionary Anthropology, Leipzig, Germany; ${ }^{\top}$ German Centre for Integrative Biodiversity \\ Research (iDiv) Halle-Jena-Leipzig, Leipzig, Germany; ${ }^{\mathrm{d} D e p a r t m e n t ~ o f ~ B i o l o g y, ~ C h a n c e l l o r ~}$ \\ College, University of Malawi in Zomba, Zomba, Malawi; 'Institute for Biodiversity and \\ Ecosystem Dynamics, University of Amsterdam, Amsterdam, The Netherlands; \\ fLukuru Wildlife Research Foundation, Kinshasa, Democratic Republic of the Congo
}

\begin{abstract}
Keywords
Eastern chimpanzee $\cdot$ Pan troglodytes schweinfurthii $\cdot$ Tool use $\cdot$ Percussive technology · Material culture
\end{abstract}

\begin{abstract}
To improve our understanding of the evolutionary origins of culture and technology in humans, it is vital that we document the full extent of behavioural diversity in our great ape relatives. About half of the world's remaining chimpanzees (Pan spp.) live in the Democratic Republic of Congo (DRC), yet until now we have known almost nothing about their behaviour. Here we describe the insect-related tool technology of BiliUéré chimpanzees (Pan troglodytes schweinfurthii) inhabiting an area of at least a $50,000-\mathrm{km}^{2}$ area in northern DRC, as well as their percussive technology associated with food processing. Over a 12-year period, we documented chimpanzee tools and artefacts at 20 survey areas and gathered data on dung, feeding remains and sleeping nests. We describe a new chimpanzee tool kit: long probes used to harvest epigaeic driver ants (Dorylus spp.), short probes used to extract ponerine ants and the arboreal nests of stingless bees, wands to dip for $D$. kohli and stout digging sticks used to access underground meliponine bee nests. Epigaeic Dorylus tools were significantly longer than the other tool types, and D. kohli tools were significantly thinner. Tools classified
\end{abstract}

\begin{tabular}{l}
\hline KARGER $\quad$ @ 2019 The Author(s) \\
E-Mail karger@karger.com \\
www.karger.com/fpr \\
This article is licensed under the Creative Commons Attribution-Non- \\
Commercial-NoDerivatives 4.0 International License (CC BY-NC-ND) \\
(http://www.karger.com/Services/OpenAccessLicense). Usage and \\
distribution for commercial purposes as well as any distribution of mo- \\
dified material requires written permission.
\end{tabular}

Thurston C. Hicks

Faculty of Artes Liberales, University of Warsaw

Ulica Nowy Świat 69

PL-00-046 Warsaw (Poland)

E-Mail clevehicks@ hotmail.com 
as terrestrial honey-digging sticks were a significant predictor for brushed and blunted tool ends, consistent with their presumed use. We describe two potential new tool types, an "ant scoop" and a "fruit hammer." We document an extensive percussive technology used to process termite mounds of Cubitermes sp. and Thoracotermes macrothorax and hard-shelled fruits such as Strychnos, along with evidence of the pounding open of African giant snails and tortoises. We encountered some geographic variation in behaviour: we found honey-digging tools, long driver ant probes and fruit-pounding sites only to the north of the Uele River; there were more epigaeic Dorylus tools to the north and more ponerine ant tools to the south. We found no evidence of termite-fishing, despite the availability of Macrotermes muelleri mounds throughout the region. This lack of evidence is consistent with the results of dung washes, which revealed a substantial proportion of driver ants, but no evidence of Macrotermes or other termites. Our results allow us to describe a new chimpanzee behavioural complex, characterised by a general similarity of multiple behaviours across a large, ecologically diverse region but with subtle differences in prey choice and techniques. We propose that this widespread and related suite of behaviours be referred to as the Bili-Uéré Chimpanzee Behavioural Realm. Possible explanations for this pattern are a recent chimpanzee expansion across the region and the interconnectedness of this population across at least the entirety of northern DRC.

(c) 2019 The Author(s)

Published by S. Karger AG, Basel

\section{Introduction}

When seen in the context of animal traditions, human culture stands out: it permeates every aspect of our lives, spanning behavioural domains ranging from toolmaking and dietary preferences to language, fashion and art [Collard and Foley, 2002]. This diversity can be contrasted with the socially learned traditions of other species, such as songbirds, bowerbirds (Ptilonorynchidae), New Caledonian crows (Corvus moneduloides) and cetaceans, which appear to be limited to one or a few behavioural domains [McGrew, 1992]. The rich behavioural diversity of our evolutionary cousin, the common chimpanzee (Pan troglodytes), provides an exception and has been argued to represent a form of non-human culture. In order to improve our understanding of how culture evolved among our hominin ancestors, we must document the traditions of as many chimpanzee populations as possible and the specieswide variation therein [Boesch, 2012]. Studying the artefacts left behind by chimpanzees is especially important to understand hominin traditions in the fossil record [Sept, 1992; Carvalho et al., 2009; Toth and Schick, 2009; Luncz et al., 2016]. Not only do some chimpanzee populations use stone tools [Boesch and Boesch-Achermann, 2000; Kühl et al., 2016] comparable to hominin stone-knapping [Mercader et al., 2002; McPherron et al., 2015], but many of their artefacts are made of perishable material such as sticks and grass, which, if used by our ancestors, would not have fossilised and therefore would remain unknown [McGrew, 1992]. Such a "panthropological" project takes on greater urgency given the threats faced by chimpanzees due to human encroachment into their habitats [Walsh et al., 2003; Campbell et al., 2008; Hicks et al., 2010], resulting not only in the extinction of populations but of their traditions as well, some of those being ancient [Mercader et al., 2002; Vaidyanathan, 2011]. 
Fig. 1. Bili-Gangu chimpanzee and tree nest. Cleve Hicks, the Wasmoeth Wildlife Foundation, 2007.

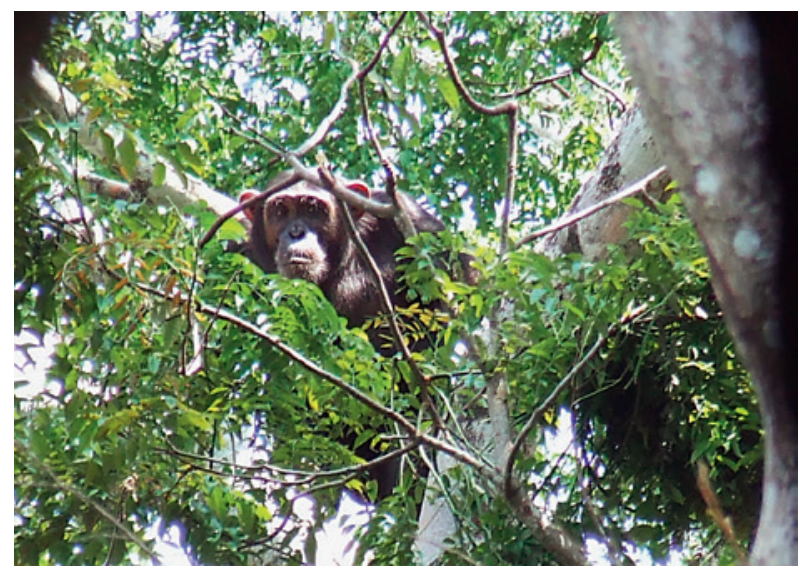

Since the publication of Whiten et al.'s [1999] seminal paper comparing chimpanzee traditions at seven long-term study sites, our knowledge about chimpanzee behavioural diversity has grown enormously. A number of recent long-term sites have added entire new tool types to the species' repertoire, such as complex tool sets (Goualougo, Republic of Congo [Sanz and Morgan, 2007]; Loango, Gabon [Boesch et al., 2009]) and spears used to skewer bushbabies (Galago senegalensis) (Fongoli, Senegal [Pruetz and Bertolani, 2007]). New study sites have also expanded the range of previously discovered behaviours by hundreds of kilometres (honey-pounding at Loango [Boesch et al., 2009]; honey-digging at Bulindi, Uganda [McLennan, 2011]). Other shorter-term studies have revealed new behaviours ranging from brush-tipped fluid probes [Lapuente et al., 2016] to "stepping sticks" and "seat sticks" (Tenkere, Sierra Leone [Alp, 1997]). The Pan African Programme [Vaidyanathan, 2011] has used camera traps to reveal previously unknown or rarely observed behaviours such as stone-piling [Kühl et al., 2016] and algae-scooping [Boesch et al., 2016] across wide geographical areas. Not all chimpanzee populations have similar-sized tool repertoires. Chimpanzees in northern Uganda, for example, especially Budongo, have a smaller tool repertoire and use few or no stick tools [McLennan, 2014]. We can now document a number of possible large-scale patterns or "behavioural realms": the use of clubs to pound open beehives in Central African chimpanzees [Fay and Carroll, 1994; Hicks, 2004; Hicks et al., 2005; Boesch et al., 2009; Sanz and Morgan, 2009], honey-digging as primarily a central and eastern chimpanzee behaviour [Hicks et al., 2005; McLennan, 2011; Estienne et al., 2017a, b; but see Boesch and Boesch, 1990, for an example in West Africa], termite nest perforation in Central Africa [Sanz and Morgan, 2007] and nut-cracking in western chimpanzees [Boesch et al., 1994; Boesch and Boesch-Achermann, 2000].

Despite such inroads, large gaps still exist in our knowledge of chimpanzee behavioural diversity. Much of our data have, until recently, come from the far western and eastern extremes of the chimpanzees' range. Little is known about the species' behaviour in the Democratic Republic of Congo (DRC), due to the country's inaccessibility and political instability. This paucity of knowledge is all the more unfortunate given that the country is currently thought to be home to about half of the world's remaining chimpanzees [Butynski, 2001; Hicks et al., 2014]. 
Here we describe a new assemblage of chimpanzee traditions found across a wide area in northern DRC. This region is one of the few remaining areas containing a large, interconnected population of chimpanzees [Hicks et al., 2014] (Fig. 1). Given that the area of our surveys between the Aruwimi and Mbomu Rivers transitions ecologically from moist tropical forest to savanna-woodland bordering the Sahel, with a corresponding climatic transition from low to high seasonality, it is the ideal place to look for large-scale behavioural patterns as well as to study the effects of ecology and resource availability on behaviour [Hicks, 2010]. We examine the distribution of behaviours across the region and investigate whether these chimpanzees use specific tool types to harvest particular resources. We aimed to test several predictions about the characteristics of the tools we found based on their presumed functions: we predicted that tools used to access deeper insect holes would be longer and thicker; that tools used to dig up underground resources (or that were thrust deeply into the ground as probes) would show more blunting and wear, as well as dirtiness. We also predicted that tool types that were not thrust into the ground but were merely dipped into a mass of swarming insects would have smaller tool diameters and show less wear.

\section{Methods}

\section{Study Area}

Between 2004 and 2016, the first author (T.H.) led a series of surveys for chimpanzees across a previously unstudied region of northern DRC, in which he collected and analysed chimpanzee tools in 19 regions as well as collecting data on other chimpanzee artefacts, dung and feeding remains. Those surveys were located between the Tele River in the south and the Mbomu River in the north, and between the towns of Bumba in the west and Bambesa in the east (online suppl. Material 1; see www.karger.com/doi/10.1159/000492998 for all online suppl. material). When the outlying points of this region are connected, they form a polygon covering $55,163 \mathrm{~km}^{2}$ [Hicks, 2010]. About half of this area lies to the north of a large river, the Uele, and half lies to the south (in order to avoid confusion, the Uéré River for which the BiliUéré region is named is a tributary of the larger Uele River). It can be divided into two major ecozones: savanna-woodland mosaic north of the Uele and moist tropical forest to the south. We searched for chimpanzees based on information received during unstructured interviews with local people. We conducted chimpanzee nest and tool/artefact surveys at 9 sites north of the Uele and 10 to the south, totalling 2,647 km of recces (non-systematic reconnaissance walks) and $231 \mathrm{~km}$ of transects in the north, and $441 \mathrm{~km}$ of recces in the south (Fig. 2). Here, we combine transects and recces into "forest walks." For 8 months during the 2012 season, K. Dierks placed 24 camera traps on animal trails and other likely areas to capture images of chimpanzees. The traps were placed within a $7 \times 3 \mathrm{~km}$ grid in the Gangu Forest, just north of the field station [Hicks, 2014].

Survey regions were relatively cohesive geographic areas, separated from other sites by roads, rivers or settlements and generally sharing the same major habitat type. In 3 cases (AkumaYoko, Nawege-Zaza and multiple locations at Bili South), because satellite maps revealed them to be connected as a unit and relatively homogeneous, we combined geographically separate forest regions to achieve an adequate sample size. Conversely, we separated for analysis 3 adjoining areas in the Bili-Gangu Region because their predominant habitat types differed substantially (Camp Louis: mostly savanna, savanna-woodland and regenerating forest; Gangu North: drier old-growth forest to the north of the Gangu River; Gangu South: more extensive seasonally flooded swamp forest south of the Gangu). Given the complex farmland-forest mosaic nature of Bambesa, the region was counted as one unit. 


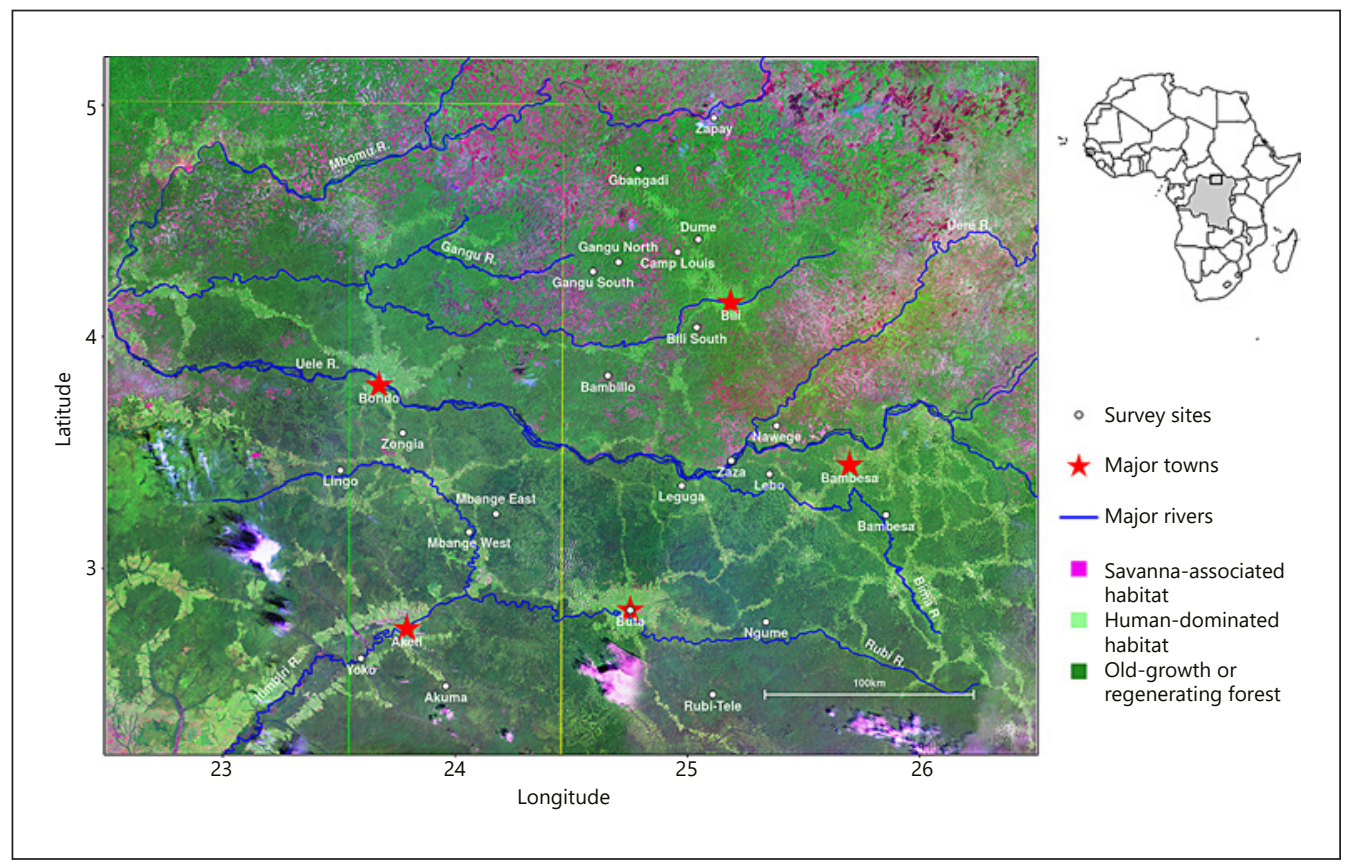

Fig. 2. Map of the study area with the survey regions labelled. The study area is divided by the large Uele River, with different habitat types predominating to the north and south. Light green areas represent zones of human disturbance (roads, fields and settlements), purple areas represent savanna-associated habitat and dark green areas represent old growth forest or regenerating forest habitat.

A large population of eastern chimpanzees (P. t. schweinfurthii) inhabits the area, apparently stable in the Bili-Gangu forests in the north [Hicks et al., 2014] but under increasing threat from bushmeat trade and other human activities in the more densely peopled south [Hicks et al., 2010]. As we walked along transects and recces, we recorded all physical evidence of chimpanzee behaviour, including tools, feeding remains [Hicks, 2010] and nest sites [Hicks et al., 2014]. We took photographs of artefacts whenever possible, recorded GPS waypoints, forest type and associated chimpanzee signs, and resource availability. Because these chimpanzees were unhabituated to researchers, we only rarely observed them behaving in naturalistic ways. Therefore, in all but a few cases, we inferred details of their behaviour from indirect evidence, mostly from abandoned artefacts [c.f. Struhsaker and Hunkeler, 1971; Boesch and Boesch-Achermann, 2000; van Schaik and Knott, 2001; Luncz et al., 2015].

\section{Rubi-Tele Pan African Programme}

Between October 2014 and May 2016, the Pan African Programme (PanAf) of the Max Planck Institute for Evolutionary Anthropology conducted a chimpanzee study in the Rubi-Tele Domaine de Chasse, just to the south of the Buta area surveyed by T.H. In total, we walked a 1,000 $\mathrm{km}$ of recces, $66 \mathrm{~km}$ of line transects and $22 \mathrm{~km}$ of strip transects (on the recces and line transects we recorded all observations, while on the strip transects we recorded only observations within $2 \mathrm{~m}$ of the transect). As was done north of the Uele, we collected tools, counted insect mounds and inspected them for possible tools, monitored camera traps and examined dung for insect remains. From here on, we will refer to the two data sets separately as "main survey regions" and "Rubi-Tele." 


\section{Data Collection}

\section{Resource Identification}

Main Survey Regions

In order to obtain data on the availability of potential food resources, between 2004 and 2008 T.H. and team collected samples of invertebrates (and more rarely vertebrates) that are known to be eaten by chimpanzees in the region or at other long-term study sites [Hicks, 2010] (Table 1). We preserved the invertebrate samples in $70 \%$ ethanol to be identified by experts. Experts also identified insects collected from chimpanzee faecal samples. Photographs of the different kinds of insects discussed in this paper and their nests can be found in Appendices Figures A1-A5.

Hymenoptera (Ants and Bees)

We collected ant specimens at 4 tool sites and from 21 ant nests, columns and swarms. In 2012, K. Dierks of PanAf collected 3 worker ant samples from colonies in the Gangu North Forest (online suppl. Material 2A). C. Schöning identified the ants and D. Roubik identified the bees. In 2012 and 2016 we excavated insect holes at presumed chimpanzee digging sites (i.e., insect holes with stick tools inserted in or lying next to them with signs of excavation) to look for traces of honey or underground beehives. We measured the depths of 33 epigaeic Dorylus holes and 24 holes of other insects (stingless bees or ants) at tool sites using a tape measure. We identified the nests and holes of epigaeic Dorylus and ponerine ants and the hives of underground and arboreal stingless bees by their size and shape, even when the insects themselves were not present.

Following Schöning et al. [2008], we classified driver ant (Dorylus) species into "epigaeic" and "intermediate" species: epigaeic species hunt in massive swarms on and above the ground surface, whereas intermediate ones limit their hunting to the leaf litter. The former respond aggressively to disturbance of their bivouacs or foraging trails, whereas the latter are timid, bite mildly and generally retreat underground when disturbed.

\section{Isoptera (Termites)}

J. Darlington and I. Deblauwe identified termites. Cubitermes and Thoracotermes, endemic African soil-feeders of the Termitinae, occur in high biomasses in African forests [Eggleton, 2000], and their distribution completely overlaps with the range of chimpanzees. These two types of forest-dwelling termites construct similarly shaped small, rounded mounds, with Thoracotermes mounds generally larger and rounder than those of Cubitermes. Cubitermes mounds are mushroom-shaped when free-standing and, like those of Thoracotermes, are sometimes found attached to the bases of trees. We frequently encountered mounds known locally as awaya, made by Macrotermes sp., some of which were identified as Macrotermes muelleri. We identified the mounds of an unidentified Cubitermes species, Thoracotermes macrothorax termites, and Macrotermes by their size and shape.

African Giant Snails (Achatina sp.) and Tortoises (Kinixys sp.)

Using shell material and photographs of smashed and living (Appendices: Fig. A6) snails from both north and south of the Uele River, B. Van Bocxlaer identified the snails as Achatina schweinfurthi (based on the height/width ratio of the shell and the number of whorls in comparison to material described in Pilsbry [1919]). Since other Achatina species occur in the area and the taxonomy of Achatina is unresolved, this identification should be considered tentative.

We photographed and collected all shell samples in two cases where evidence indicated that chimpanzees had pounded open tortoises. C. Stanford identified the tortoise species potentially pounded by the chimpanzees.

Rubi-Tele

The PanAf team gathered samples of insects from colonies, including those known to be eaten by chimpanzees, as well as those found at tool sites and in dung (for the latter, see online suppl. Material 2B). The researchers also gathered Macrotermes soldiers, but these await expert identification at the species level. 
Table 1. Characteristics of invertebrates targeted by the Bili-Uéré chimpanzees (see Appendices: Fig. A1-A6)

\begin{tabular}{|c|c|}
\hline Taxon & Characteristics \\
\hline $\begin{array}{l}\text { Epigaeic driver ants } \\
\text { (Dorylus sp.) }\end{array}$ & $\begin{array}{l}\text { Dorylus wilverthi and } D \text {. terrificus: we could easily identify these } \\
\text { species by the enormous size of their swarms, their aggressive } \\
\text { biting behaviour and the distinctive appearance of their soldiers; } \\
\text { we could identify their nests as deep cavernous excavations at the } \\
\text { bases of large trees, usually surrounded by earthen hills ranging } \\
\text { from approx. } 1 \times 1 \text { to } 2 \times 2 \mathrm{~m}\end{array}$ \\
\hline $\begin{array}{l}\text { Non-epigaeic driver ants } \\
\text { (Dorylus kohli) }\end{array}$ & $\begin{array}{l}\text { Dorylus kohli holes were shallow depressions }(<0.5 \mathrm{~m} \text { deep) } \\
\text { lacking hills, and, unlike those of epigaeic Dorylus, they were } \\
\text { usually not found at tree bases. These ants lack large aggressive } \\
\text { soldiers, possessing bites so mild that we were easily able to } \\
\text { handle tools on which they were swarming }\end{array}$ \\
\hline $\begin{array}{l}\text { Ponerine ants } \\
\text { (Megaponera analis, } \\
\text { Paltothyreus tarsatus) }\end{array}$ & $\begin{array}{l}\text { The presence of Ponerinae species (Megaponera analis - } \\
\text { formerly Pachycondyla analis, and Paltothyreus tarsatus - } \\
\text { formerly Pachycondyla tarsata) was indicated by small }<1 \times 1 \mathrm{~m} \\
\text { dirt hills, each peppered with one or more (up to } 10 \text { ) small holes; } \\
\text { several of these sites had multiple hills, with more than a dozen } \\
\text { covering a small area, whereas others (of both species) had single } \\
\text { or double holes }\end{array}$ \\
\hline $\begin{array}{l}\text { Arboreal stingless bees } \\
\text { (Meliponula sp.) }\end{array}$ & $\begin{array}{l}\text { We found stingless beehives of Meliponula ferruginea and } \\
\text { M. bocandei in the knots of trees with the bees still present inside }\end{array}$ \\
\hline $\begin{array}{l}\text { Terrestrial stingless bees } \\
\text { (Meliplebeia lendliana, } \\
\text { possibly M. ferruginea and } \\
\text { M. bocandei) }\end{array}$ & $\begin{array}{l}\text { Terrestrial stingless beehives were characterized by single deep } \\
\text { ( }>0.5 \mathrm{~m} \text { ) round holes, lacking mounds, generally not found at the } \\
\text { bases of large trees; chimpanzees sometimes excavated pieces of } \\
\text { the beehive, or we found honey and comb by digging deeper into } \\
\text { the hole; using probes, we also identified honey as being present } \\
\text { inside some holes }\end{array}$ \\
\hline $\begin{array}{l}\text { Termites (Cubitermes sp., } \\
\text { Thoracotermes } \\
\text { macrothorax) }\end{array}$ & $\begin{array}{l}\text { We found Cubitermes sp. or T. macrothorax mounds pulverized } \\
\text { against a tree root, rock or against the ground. At fresh pounding } \\
\text { sites, we often found wiggling termite adults and/or larvae within } \\
\text { the broken fragments. T. macrothorax mounds were larger and } \\
\text { rounder than those of Cubitermes, and they had soft bumps } \\
\text { spread across the surface; Cubitermes mounds, whether free- } \\
\text { standing or attached to the sides of trees, were generally } \\
\text { mushroom-shaped }\end{array}$ \\
\hline $\begin{array}{l}\text { African giant snails } \\
\text { (Achatina schweinfurthi) }\end{array}$ & $\begin{array}{l}\text { We found African giant snails (Achatina schweinfurthi) cracked } \\
\text { open, often in piles, against tree buttresses, roots or, in rare cases, } \\
\text { rocks; because other animals crack open these snails with their } \\
\text { jaws or (accidentally) by stepping on them, we counted only sites } \\
\text { with clear pounding marks on substrates within } 10 \mathrm{~m}\end{array}$ \\
\hline
\end{tabular}

The Bili-Uéré Chimpanzee Behavioural Realm

Folia Primatol 2019;90:3-64 
Table 2. Ants collected in chimpanzee dung samples in the Camp Louis, Gangu and Rubi-Tele Forests of the Bili-Uéré region

\begin{tabular}{|c|c|c|c|c|c|c|}
\hline Observation period & Region & $\begin{array}{l}\text { Dung } \\
\text { samples, } \\
n\end{array}$ & $\begin{array}{l}\text { With } \\
\text { ants, } \\
n\end{array}$ & $\begin{array}{l}\text { With } \\
\text { ants, } \\
\%\end{array}$ & Researcher & Identified by \\
\hline Oct 2004 to July 2005 & Camp Louis & 42 & 3 & 7.1 & T.H. & Local assistants \\
\hline Oct 2004 to July 2005 & Gangu East & 4 & 0 & 0.0 & T.H. & Local assistants \\
\hline Sept 2012 to March 2013 & Gangu East & 21 & 7 & 33.3 & K.D. & Caspar Schöning \\
\hline Oct 2014 to May 2016 & Rubi-Tele & 73 & 7 & 9.6 & P.D., R.F., A.E. & Caspar Schöning \\
\hline
\end{tabular}

T.H., Thurston C. Hicks; K.D., Karsten Dierks; P.D., Paula Dieguez; R.F., Rumen Martin Fernandez; A.E., Ayuk Emmanuel Ayimisin.

\section{Faecal Analyses}

Main Survey Regions

Between October 2004 and July 2005, T.H. conducted 46 faecal analyses of fresh chimpanzee faeces found in the forests around Camp Louis $(n=42)$ and Gangu $(n=4)$ from 33 dung sites (Camp Louis: 29 sites; Gangu: 4 sites). In 2012, as part of PanAf, K. Dierks collected 21 samples of chimpanzee dung (14 in September and October 2012 and 7 in March 2013), some of which we later found to contain ant remains. C. Schöning identified ant parts in 7 of these samples.

We inspected dung samples for insects during two study periods in the Gangu and Camp Louis Forests (Table 2) [Hicks, 2010]. During the 2004-2005 season, after weighing the dung and washing it in a mesh sieve (mesh size: approx. $1 \mathrm{~mm}$ ), we separated it into its constituent parts with tweezers. We then weighed each type of plant or animal component following separation and saved potential animal tissue for later identification [McGrew et al., 2009]. Local assistants aided in identifying seeds, plant parts and animal tissue. At Rubi-Tele and during the Gangu 2012 season, the PanAf researchers used a similar method but without weighing the samples; material was identified and stored in tubes.

\section{Rubi-Tele}

The Rubi-Tele team carried out dung washes between October 2004 and May 2016 (Table 2). The researchers removed any animal remains; which they washed, dried and stored in silica gel for later analysis if they could not be identified immediately.

\section{Tool and Tool Site Identification}

Main Survey Regions

Tool Site Identification. T.H. recorded data at the majority of the 19 main survey regions. In other cases (i.e., at Bambillo and Dume), field assistants trained by T.H. recorded the data with measurements, photos, films and GPS waypoints. In the rare cases where tools were found at the same location but were of different ages and/or were associated with different insect holes, we counted them as different sites. We estimated the age of each tool based on freshness of tool material (fresh $=$ used within the past 2 days; recent $=$ between 3 days and 2 weeks; old $=$ older than 2 weeks). For the analysis, we lumped fresh and recent tools together. We recorded if the tool was sticking from a nest or hole, or its distance to such resources. For all potential tool sites, we recorded a GPS waypoint. We photographed potential tools in situ and mapped out their exact positions.

Tool Identification. With a few exceptions (Table 3), we only recorded a stick, vine or herb as a tool if it was in association with an insect hole or mound (i.e., inside, on top of or $<1 \mathrm{~m}$ from the mound or hole) and had two or more of the following features: projecting from inside an insect hole, evidence of modification by the stripping of bark and/or leaves, smeared with dirt along part of the shaft from where it had been in the ground (dirty end[s]), blunted end(s), brushed end(s) and source plant from which the stick had been detached found nearby (Table 3; online suppl. Material 3). Six of the 245 objects tentatively identified as tools in the field did not fit our criteria, and we do not include them here. Eighty percent of the 239 objects classified as tools had 
Table 3. Criteria used to classify tools (numbers and percentages) at the 19 main survey regions

\begin{tabular}{|c|c|c|c|c|c|c|}
\hline \multicolumn{4}{|c|}{ Combinations of evidence types } & \multirow{2}{*}{$\begin{array}{l}\text { Tool count } \\
30\end{array}$} & \multirow{2}{*}{$\begin{array}{l}\text { Percentage } \\
12.6\end{array}$} & \multirow{2}{*}{$\begin{array}{l}\text { Tool status } \\
+\end{array}$} \\
\hline Projecting & Modified & Usage signs & Source found & & & \\
\hline Projecting & Modified & Usage signs & & 26 & 10.9 & + \\
\hline Projecting & Modified & & Source found & 14 & 5.9 & + \\
\hline Projecting & Modified & & & 7 & 2.9 & + \\
\hline Projecting & & Usage signs & Source found & 49 & 20.5 & + \\
\hline Projecting & & Usage signs & & 36 & 15.1 & + \\
\hline Projecting & & & Source found & 19 & 7.9 & + \\
\hline \multirow[t]{8}{*}{ Projecting } & & & & 16 & 6.7 & Uncertain tool \\
\hline & Modified & Usage signs & Source found & 2 & 0.8 & + \\
\hline & Modified & Usage signs & & 1 & 0.4 & + \\
\hline & Modified & & Source found & 3 & 1.3 & + \\
\hline & Modified & & & 9 & 3.8 & Probable tool \\
\hline & & Usage signs & Source found & 6 & 2.5 & + \\
\hline & & Usage signs & & 7 & 2.9 & Uncertain tool \\
\hline & & & Source found & 1 & 0.4 & Uncertain tool \\
\hline \multicolumn{3}{|c|}{ With other tools only } & & 13 & 5.4 & Uncertain tool \\
\hline \multicolumn{3}{|l|}{ Total } & & 239 & 100 & \\
\hline
\end{tabular}

Despite our use of these criteria, some uncertainties remain, in particular with those assigned tools which met $<2$ of the criteria or for which the data were lacking (labelled here "uncertain tool"). "Probable tools" refers to "modified" being the only criterion. "+" means 2 or more of the criteria were fulfilled. We cannot rule out that in some cases objects may have been incorrectly classified as tools.

two or more of the features listed above. In $14.6 \%$ of the remaining cases, we found only one feature, but found the object in association with other tools. In the remaining $5.8 \%$ of cases, mostly at the Bambillo site, the field assistants failed to record data on tool characteristics other than length and association with insect mounds and nests, but we classified the objects as tools based on the judgement of the assistants, their association with other tools and from reviewing photographs of the sites. Where relevant, we measured: the length of mud stains on the tools; depth of insertion; presence and type of insects; dimension, number and depth of insect holes; any evidence of chimpanzee presence (dung, hair, foot prints); forest visibility (clear $\leq 1 \mathrm{~m}$, medium between $>1 \mathrm{~m}$ and $\leq 5 \mathrm{~m}$, open $>5 \mathrm{~m}$ ) and type (mixed, swamp, riverbed, hillside, field, regenerated field, savanna, savanna woodland, hillside or mono-dominant Gilbertiodendron forest). We analysed the following 6 tool characteristics: length, diameter, blunt end(s) (yes/no), brushed end(s) (yes/no), dirty end(s) (yes/no) and signs of intentional modification (yes/no). The latter refers to peeled ends and stripped leaves.

Due to the possibility that branches may have fallen into insect dwellings or that wear patterns on sticks may have been caused by something other than chimpanzees, we cannot rule out that some of these tool-like objects might have been mistakenly classified as tools. In the majority of cases this was unlikely due to the multiple criteria used to identify the potential tools. Some of the modified objects without clear signs of wear (3.8\% of cases) may have been discarded fragments from the process of tool-making, which were not used by the chimpanzee as a tool (we found such fragments in association with a number of tool sites, as was the case in McGrew and Collins [1985]). For 5 of the D. kohli tools, we did not measure tool diameters. Using films of the uniformly slender tools held in J.S.'s hands, we later estimated them to be about $2 \mathrm{~cm}$ in circumference $(0.65 \mathrm{~cm}$ diameter).

Rubi-Tele

At Rubi-Tele, out of the 266 total stick tools recorded at 170 sites, the researchers transported 253 to the Max Planck Institute of Evolutionary Anthropology in Leipzig. Although the researchers did not record tool use characteristics in the field, other than length and diameter, T.H. and P.D. later inspected these sticks in the lab, and they had the following characteristics: $49 \%$ had been modified on both ends, and an additional $18 \%$ had been modified on both ends 
Table 4. Criteria used to determine the resource present at a chimpanzee tool site

\begin{tabular}{|c|c|c|c|c|}
\hline Evidence & $\begin{array}{l}\text { Assigned } \\
\text { resource type }\end{array}$ & $\begin{array}{l}\text { Sites, } \\
n\end{array}$ & $\begin{array}{l}\text { Tools, } \\
n\end{array}$ & $\begin{array}{l}\text { Sites } \\
\text { assigned } \\
\%\end{array}$ \\
\hline Presence of epigaeic Dorylus ants & Epigaeic Dorylus & 11 & 43 & 14.3 \\
\hline Presence of epigaeic Dorylus nests & Epigaeic Dorylus & 10 & 34 & 13.0 \\
\hline $\begin{array}{l}\text { Presence of characteristic cavernous holes } \\
\text { beneath roots of large tree }\end{array}$ & Epigaeic Dorylus & 2 & 11 & 2.6 \\
\hline Presence of bees, honey and/or wax & $\begin{array}{l}\text { Stingless bees } \\
\text { (terrestrial and } \\
\text { arboreal) }\end{array}$ & 9 & 26 & 11.7 \\
\hline Presence of ponerine ants & Ponerine ants & 4 & 16 & 5.2 \\
\hline Presence of Dorylus kohli & Dorylus kohli & 1 & 3 & 1.3 \\
\hline $\begin{array}{l}\text { Presence of Dorylus kohli-type shallow wide } \\
\text { holes, earth disturbed with hands }\end{array}$ & Dorylus kohli & 3 & 9 & 3.9 \\
\hline $\begin{array}{l}\text { Presence of characteristic ponerine nests, } \\
\text { no digging }\end{array}$ & Ponerine ants & 7 & 13 & 9.1 \\
\hline $\begin{array}{l}\text { Presence of a single excavated hole with no } \\
\text { mound }\end{array}$ & $\begin{array}{l}\text { Stingless bees } \\
\text { (terrestrial) }\end{array}$ & 5 & 16 & 6.5 \\
\hline $\begin{array}{l}\text { Presence of a characteristic small ponerine } \\
\text { hole(s), tool projecting, no mound (tool } \\
\text { sites } 39,43 \text { and GAN3) }\end{array}$ & Ponerine ants & 3 & 6 & 3.9 \\
\hline Insufficient evidence & Unknown & 22 & 62 & 28.6 \\
\hline Totals & - & 77 & 239 & 100 \\
\hline
\end{tabular}

We based resource assignment strictly on evidence related to the site; we did not use characteristics of the tools themselves for the assignment. Rubi-Tele data are not included here.

combined with signs of use (blunt, brushed or impacted mud); 19\% had been modified on one end only, and an additional $9 \%$ had modifications on one end combined with one or more signs of use. Finally, 5\% showed no signs of modification or use (online suppl. Material 3).

\section{Resource Assignment for Tools and Tool Sites}

Main Survey Regions

For each of the validated tool sites, we determined the most likely invertebrate resource harvested with those tools: epigaeic driver, $D$. kohli and ponerine ants, and arboreal and terrestrial beehives. In order to prevent circular reasoning, we avoided using any of the characteristics of the tools themselves to determine the resource present at the site. We assigned resources based strictly on site characteristics such as presence of insects, nests, mounds and holes (Table 4). We assigned tools from sites not fitting these criteria to an "unknown" resource type and did not consider them further in the analysis.

Projecting from Insect Hole. Sticks may occasionally fall from trees and land in insect nests and thus end up sticking up out of them, but this becomes more unlikely when multiple tools are 
found projecting from a nest or projecting tools show other signs of modification. We found a number of large tools wedged firmly up to $60 \mathrm{~cm}$ into subterranean insect holes and nests.

Used. At least one sign of use: blunt, dirty or brushed. Blunt refers to the wooden tip of one or both ends of the stick crushed and pushed backwards, apparently from being thrust into a hole. Brushed refers to a fan-shaped widening of one or both ends of the stick; we do not know if these were intentionally formed by the chimpanzees or a side effect of tool detachment or use. We only included a tool as dirty if the dirt appeared to be of the same colour and consistency of the nearby hole in an excavated or probed insect dwelling. In most cases the marks left by the dirt ended abruptly along the length of the tool, suggesting that this was the depth to which the tool had been introduced into the insect dwelling.

Modified. Stripped of bark and/or leaves. At a number of sites, chimpanzees strip leaves and bark from sticks prior to using them as tools (first described in van Lawick-Goodall [1968]). We found indirect evidence at the tool sites indicating that leaves and branches had been peeled off prior to the tool's insertion into the ground (i.e., the leaves detached from the distal end lacked mud found on the end itself and were cast aside near the source tree).

Source Found. We found the plant used to make the tool. When a potential tool matched to a nearby source horizontal to the object (as determined by the investigator and assistants carefully examining the overlap between the tear patterns on the tool with torn-off plants nearby of the same species), it was thus clear that the object had not fallen from above but had been removed from the source plant and transported to the insect dwelling [McLennan, 2011].

With Other Tools Only. Refers to sticks found at insect nests in association with other sticks categorized as tools that were, in the field, categorized as tools by T.H. or experienced workers but for which, due to field conditions, we failed to record relevant details, except for, in most cases, length. T.H. reviewed photographs of these sticks and judged them most likely to be tools. This procedure mostly applies to the Bambillo site, where the potential tools that were gathered and measured were later burned by unknown persons along with the Gangu research camp, thus preventing further examination.

\section{Rubi-Tele}

Ant species identified from samples collected at Rubi-Tele matched northern species. Black ants referred to ponerine ants and Polyrachis sp., while red ants referred to Dorylus ants (and in one case Camponotus sp.). The researchers collected Macrotermes soldiers with their distinctive large heads and mandibles, but species identification by an expert is lacking.

\section{Insect Availability}

Main Survey Regions

To estimate quantitatively the availability of certain key insect species (epigaeic and intermediate species of Dorylus, termites [Macrotermes, Cubitermes and Thoracotermes spp.] and ponerine ants), T.H. conducted systematic counts along transects and recces at 12 selected sites ( 3 to the north of the Uele and 9 to the south). We omitted the more cryptic beehives and nonepigaeic Dorylus swarms (i.e., non-surface-swarming "intermediate" species) from our analyses, as they were too difficult to detect on forest walks.

Epigaeic Dorylus and Ponerine Ants

To the north of the Uele River, the ant availability surveys were subsets of chimpanzee artefact surveys. We counted epigaeic Dorylus and ponerine nests, columns and swarms along line transects and recces walked in 2005 and 2012 [Hicks et al., 2014]. South of the Uele, we continuously looked for both chimpanzee signs and ants on all walks. Surveys in the different regions took place in different months and in many regions were limited to either wet or dry seasons (dry: December to March; wet: April to November; online suppl. Material 5).

On our 2012 survey, encounter rates for epigaeic Dorylus nests, columns and swarms and ponerine ant nests were $0.673 / \mathrm{km}$ on recces versus 0.846 on transects (online suppl. Material 6). Sample sizes for each were too small for statistical comparison, but we judged the rates, especially for insects, to be similar enough to combine transects and recces into one category - forest walks. 
Termites

We counted Macrotermes termite mounds in the same manner as described above, and in the north we also counted Macrotermes swarms. At Camp Louis/Gangu North we counted $\mathrm{Cu}$ bitermes and T. macrothorax mounds along $5.2 \mathrm{~km}$ of transects (for all but $2.0 \mathrm{~km}$ of this distance, because we did record the mound type, we lumped the two genera together as "Cubitermes/Thoracotermes" combined). We did not record or identify the numerous termite mounds encountered in the savannas, which were very different in size, shape and colour from the "forest mounds" made by M. muelleri. Although we cannot rule out that they may have been potential chimpanzee prey species, our evidence showed that chimpanzees rarely visited the savannas; therefore, we limited our Macrotermes surveys to the forested areas.

Rubi-Tele

The PanAf research team walked a mixture of line transects and recces, totalling $1,066 \mathrm{~km}$, plus an additional $22.0 \mathrm{~km}$ of strip transects. The researchers counted nests and insects of the same taxa that were recorded by Hicks' teams in the main survey regions.

\section{Identification of Tool Plant Species}

Between 2006 and 2007, J.S. compiled a herbarium of plants from Bili with a focus on those used by chimpanzees for feeding, nest-making or tool-making. Corneille Ewango, Jan Wieringa, Folkert Aleva and Marc Sosef identified many of these plant samples at the Wageningen Herbarium in the Netherlands [Hicks, 2010].

\section{Percussive Technology}

We collected data on "pounding sites" where chimpanzees used percussive technology to process several kinds of food items including fruits and termite mounds against a substrate such as a tree trunk or a rock. We encountered pounding sites on forest walks; on occasion, we were drawn in by the sounds of pounding. We recorded the presence or absence of a substrate within $10 \mathrm{~m}$ with a potential strike mark on it (bruised bark on a tree, sometimes with embedded fragments or mud from the smashed object). With the exception of a few termite mounds associated with chimpanzee evidence that appeared to have been pounded open on the ground, we consider here only sites with strike marks within $10 \mathrm{~m}$. We also recorded and photographed pounded termite mounds and snails at Rubi-Tele.

\section{Data Analysis}

To investigate how tool characteristics related to the resources they were used for in the main survey regions, we ran a principal components analysis (PCA). Subsequently, we tested whether the tool types could be discriminated from one another using tool length and diameter in a discriminant function analysis combined with a permutation test [pDFA; Mundry and Sommer, 2007; see below]. We tested specific hypotheses about the presumed use of the tools with Generalized Linear Mixed Models (Baayen, 2008).

We conducted a PCA using the prcomp function of R [R Core Team, 2014]. The data matrix contained the six tool characteristics and dummy variables for the assigned resource types in the columns and the 161 tools with complete shape data in the rows. We centred each column in the matrix and scaled it to unit variance. Based on factor loadings, we identified tool length and diameter as factors with a large contribution to variation in tool characteristics.

We used tool length and diameter in a permuted Discriminant Function Analysis (pDFA). The pDFA function was written in R by R.M. and is in turn based on the function lda (linear discriminant analysis) of the R package MASS [Venables and Ripley, 2002]. The analysis again contained the 161 cases with complete shape data. We tested the possibility of discriminating between the tools used for different resource types while controlling for the non-independence of tools per tool site (since we often collected multiple tools from the same tool use site, potentially causing pseudo-replication). In the pDFA, we permuted the tool site type (i.e., the resource for which the tools were used) across the 55 tool sites to which we could assign a resource. This means that we always assigned all tools found at a given site to the same (but permuted) resource type. 
The total number of permutations was 1,000, and the number of random selections measuring performance of the DFA on unpermuted data was 100.

To further test whether tool characteristics reflected their presumed use for the harvested resource, we used 6 Generalized Linear Mixed Models [Baayen, 2008], one for each characteristic. For each tool characteristic we formulated one a priori hypothesis reflecting our reasoning about the presumed use of the tool. This meant constructing a binary predictor specifying whether the resource type of the site at which the tools were found was of a certain type or not. For instance, we can expect blunted ends for tools associated with digging out resources if the tools were actually used for digging. Hence, as a predictor for blunted ends (response), we coded whether the site was a terrestrial honey site (no/yes). We included one such predictor as the single fixed effect into a model. We included tool site as random effect to account for the fact that in most cases several tools came from the same tool site. We used binomial models and a logit link function [McCullagh and Nelder, 1998] in all cases except for tool length and diameter, where a Gaussian error structure and identity link were specified, and we log-transformed the response variables in order to achieve a more symmetrical distribution. We checked the assumptions of the Gaussian models by inspecting the distribution of the residuals (normality of residuals assumption) as well as by plotting the residuals against fitted values (homoscedasticity of the residuals). The diagnostics for the tool length model indicated no problems, but even after log-transformation the model for tool diameter still showed an increase in error variance with increasing fitted value. The results of this model should therefore be interpreted with some care. We tested the contribution of the fixed effects predictor by removing it from the models and comparing the resultant null model (that contained only the random factor "site") to the full model. We used a likelihood ratio test to test whether the removal of the predictor caused a significant drop in the fit [Barr et al., 2013].

\section{Results}

\section{Resource Identification by Experts}

\section{Main Survey Regions}

Ant Presence and Consumption

We confirmed that at least 2 species of epigaeic Dorylus (D. wilverthi and D. terrificus) and 2 intermediate Dorylus species (D. opacus and D. kohli) were present in the Bili region [Hicks, 2010], along with 2 species of ponerine ant, Megaponera analis and Paltothyreus tarsatus. We identified these species, with the exception of D. opacus, from samples gathered south of the Uele River. We identified Camponotus spp. and Oecophylla longinoda, ants eaten elsewhere by chimpanzees, from samples collected at Bili-Gangu. We found the insects listed in online supplementary Material 7A-E associated with chimpanzee tool sites. We confirmed that the chimpanzees north of the Uele River use tools to prey upon epigaeic driver ants D. wilverthi, whereas the target species at the South Uele tool site found at Leguga was D. terrificus. In June 2005 at Gangu South, T.H. filmed a group of chimpanzees dipping for non-epigaeic "intermediate" driver ants later identified as D. kohli. An expert identified ponerine ants at the South Uele tool site at Lebo as M. analis; north of the Uele (at Bili South), we collected ants of the same species from a mound that had been manually excavated by chimpanzees [Hicks, 2010].

Termite Presence and Consumption

An expert identified termite samples obtained from sites both north (Gangu North) and south (Mbange East) of the Uele River as M. muelleri, called awaya in the 
Zande language. The distinctive mounds of Cubitermes spp. and T. macrothorax termites were common on both sides of the Uele River. An expert identified Cubitermes from samples collected at the northern sites of Gangu North and Bili South (the former at a chimpanzee pounding site), and samples identified as T. macrothorax came from the southern sites of Mbange East and Leguga. We found no evidence that chimpanzees consumed Macrotermes termites at any of the sites. We documented abundant evidence of chimpanzees pounding open the mounds of Cubitermes sp. and T. macrothorax (see "Percussive Technology" section below, subsection "Termite Mound Pounding against a Substrate").

Bee Presence and Consumption

We identified stingless bees at multiple honey predation sites north of the Uele (Camp Louis and Gangu North), representing both arboreal (Meliponula [Axestotrigona] ferruginea and M. bocandei) and terrestrial (Meliplebeia lendliana) species. Both stingless and stinging bees (Apis mellifera) were abundant in the South Uele Forests, although we collected no samples for identification. We found no honey tool sites south of the Uele River. At the two arboreal honey tool sites found in the Camp Louis and Gangu North regions (the target species were later identified as M. ferruginea and $M$. bocandei), we encountered the tools in a pile directly beneath knots containing occupied beehives. An expert identified the bees found at two terrestrial honey sites found in 2016 as M. lendliana. The excavated underground beehives discovered on 23 August and 18 September 2012 were made by Meliponula underground stingless bees (probably M. ferruginea and M. bocandei).

\section{Rubi-Tele}

At Rubi-Tele, the insect fauna was similar to that found in main survey regions to the north (online suppl. Material 8), including the epigaeic driver ant $D$. wilverthi and two intermediate species D. rubella and D. opacus. Also present were both species of ponerine ants preyed on by chimpanzees at a number of the main survey regions.

\section{Faecal Analyses}

\section{4-2005 Season (Camp Louis/Gangu North and South Forests)}

Of the 46 dung wash samples examined at Camp Louis, 3 (6.5\%) contained body parts of epigaeic Dorylus ants, including the heads of soldiers with large mandibles (Table 2). We found these in 3 (9\%) of the 33 wet season (April to November) samples but in none of the 13 dry season (December to March) samples. Eighteen percent of the dry weight of one dung sample collected on 30 November 2004 was made up of epigaeic Dorylus body parts (Appendices: Fig. A7a), while in samples found in October 2004 and May 2005, these ants made up to 4\% of the samples' weights. We found no termite, bee or other insect remains in any of the samples, despite evidence that chimpanzees were pounding open termite mounds and digging/probing for honey. Although we conducted no systematic dung washes south of the Uele River, at Akuma in June 2008, T.H. found abundant D. kohli body parts in a dung sample (Appendices: Fig. 7b), representing our only evidence of ant consumption by chimpanzees in the forests of Aketi, Mbange, Zongia and Lingo to the west of Buta. 


\section{2-2013 Season (Gangu North Forest, PanAf)}

We found ants in 7 out of the 21 dung samples collected (epigaeic Dorylus in $14 \%$, intermediate Dorylus in 24\%, weaver ants in 5\%) (online suppl. Material 2A). Five of the 14 wet season samples (36\%) contained ants. Two of the 7 samples found on a single day during the dry season contained ants belonging to both of the epigaeic and intermediate Dorylus species, which are found at Bili. In 2 faecal samples, more than one ant species were present in the same sample (sample one -D. opacus and $O$. longinoda; sample $2-D$. wilverthi and D. opacus). We found no termite, bee or vertebrate remains.

\section{Rubi-Tele}

As elsewhere, ants were the only animal remains found in faeces (online suppl. Material 2B). One out of the 73 dung samples contained the ponerine ant $P$. tarsatus, and another sample contained Oecophylla ants. Epigaeic Dorylus were present in $4.1 \%$ of the samples and intermediate Dorylus in $1.4 \%$ (despite no tools having been found at Dorylus nests).

\section{Tool Characteristics}

\section{Distribution of Stick Tools across Resource Types at the Main Survey Regions}

The assignment of each tool site to the likely type of invertebrate resource preyed upon by the chimpanzees, which was based strictly on site characteristics (presence of insects, nests and holes) and not on tool characteristics, allowed us to attribute to a resource type 177 out of 239 tools at 55 out of 77 sites (Table 4). We assigned the remaining 62 tools from 22 sites to an unknown resource type and did not consider them further in the analyses. The PCA (Fig. 3; online suppl. Material 9) of all stick tools and the 6 characteristics investigated showed a clear pattern, with clusters for all 5 tool types. The first principal component (PC1; Fig. 3a) explained 23.2\% of the variation, with tool length and diameter having a strong projection. The tools used to harvest epigaeic Dorylus ants all fell in this class and therefore were long and (probably as a consequence) had a relatively large diameter. All other tool types were shorter and had lower PC1 values. The tools for D. kohli were the shortest and thinnest of all tools.

We interpret the PC2, which explained $18.9 \%$ of the variation, as a measure of the level of wear and modification of the tool. All of these characteristics (blunted, dirty, brushed, modified) projected in the same direction, roughly parallel to PC2. Therefore, tools with high values for PC2 tended to be dirty/blunted/brushed and modified, while low values indicated clean unmodified tools without signs of wear. The D. kohli tools and tools used to harvest honey from trees fell into this latter category. Terrestrial honey tools on the other hand appeared to be relatively blunted and dirty, consistent with their presumed use to dig out a resource.

The PC3 (Fig. 3b) explained another 13.3\% of the variation. Together the first 3 axes still only captured slightly more than half of the total variation, yet the 3 PCs showed clearly that the tools clustered into distinct types for each resource.

Differences in Tool Characteristics according to Resource Types

A pDFA confirmed that tool types could be discriminated from one another based on their lengths and diameters $(n=161$ tools, expected percentage correctly 

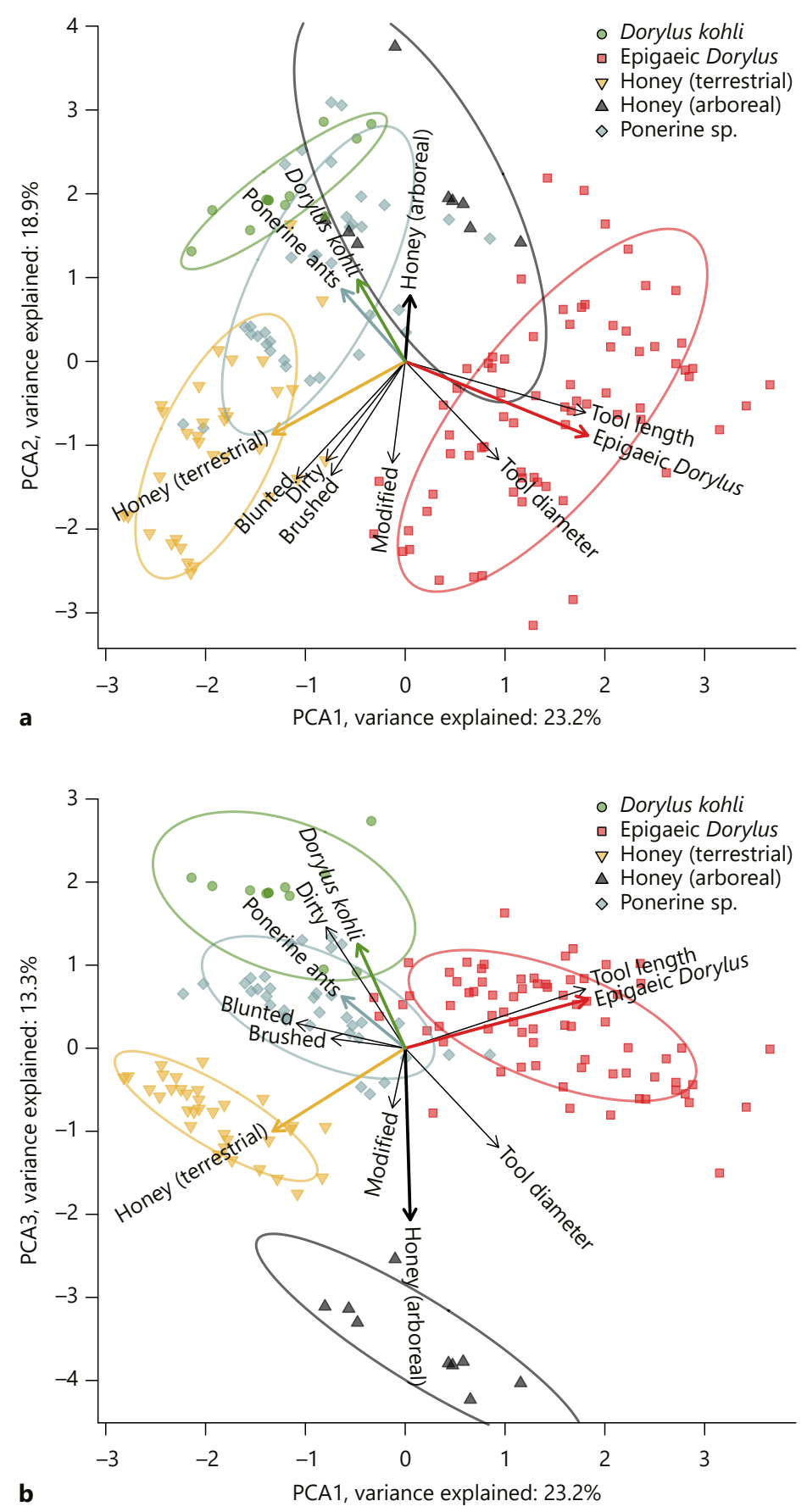

Fig. 3. Principal components analyses (PCAs) of all Bili-Uéré chimpanzee stick tools and the 6 tool characteristics investigated. a PCA axes 1 and 2. b PCA axes 1 and 3. 
cross-classified $=22.2 \%$, observed percentage correctly cross-classified $=48.0 \%, p=$ $0.001)$. To test whether the length or diameter of the tools showed a multimodal pattern possibly indicative of a tool set [cf. Sanz et al., 2010], we performed dip tests of unimodality [Hartigan and Hartigan, 1985] for tools for all resources, but found no indications of multimodality (online suppl. Material 10).

\section{Camera Trap Data and Other Tool Use Footage}

In Gangu North Forest, camera traps recorded 97 clips of chimpanzees over the 8 -month period during which they were in place [Hicks, 2014]. Two of these clips involved chimpanzees using or carrying tools. We acquired no comparable clips of chimpanzee tool use from Rubi-Tele. In 2005, T.H. used a hand-held camera to film a group of chimpanzees dipping for D. kohli on the ground in the Gangu South Forest.

\section{Stick Tool Properties and Their (Presumed) Use}

Given the aggressive behaviour of epigaeic Dorylus ants and the fact that their holes are deeper, we expected that the tools used to harvest them would be longer than average. This was indeed the case (Fig. 4; Table 5). From camera trap footage as well as the position of the tools beside the ant holes, D. kohli tools appeared not to have been thrust into the ground but used for dipping only. We therefore expected " $D$. kohli site (yes/no)" to be a significant predictor of small tool diameters, which was the case (Table 5). Assigned D. kohli tools were all $\leq 0.75 \mathrm{~cm}$ in diameter, and $83 \%$ of them were $\leq 0.65 \mathrm{~cm}$ in diameter. For the other tool types these percentages were lower (0-13\%) (online suppl. Material 11).

Tools assigned to the terrestrial honey group were significant predictors for the presence of brushed and blunted ends, consistent with their presumed function of digging up honey. When we limited our consideration to those terrestrial honey sites with either wax or honey present $(n=7)$, we found all of them to be associated with digging. None of the tool sites for the other tool types were ever associated with digging, except for 1 possible digging site out of 9 ponerine tool sites. We expected honey-digging tools to have significantly more dirty ends, but only a trend was found in this direction ( $p=0.078$, Table 5$)$. We also expected tools for harvesting ponerine ants to be associated with dirtiness, but we could not confirm this prediction.

\section{Tool Characteristics Summary}

At the main survey regions, we found 77 candidate tool sites, of which we were able to assign 55 to a particular resource type (Fig. 5; Table 4). Analysis of diameter, size and signs of usage patterns showed that the tools assigned to different resources showed significantly different characteristics in concordance with their hypothesized methods of use. In their extractive foraging, chimpanzees preyed upon at least 5 different types of insects using the following tools (Appendices: Fig. A8-A12, online suppl. Material 7):

Long Ant-Dipping Probes. Thick solid sticks found embedded up to $60 \mathrm{~cm}$ into holes inside ant nests, with no signs of digging, used to harvest epigaeic Dorylus (north of the Uele River only).

Short Ant-Dipping Probes. Similar to long ground probes but shorter; used to harvest ponerine ants and, at one South Uele site, epigaeic Dorylus. Signs of digging were rare. 


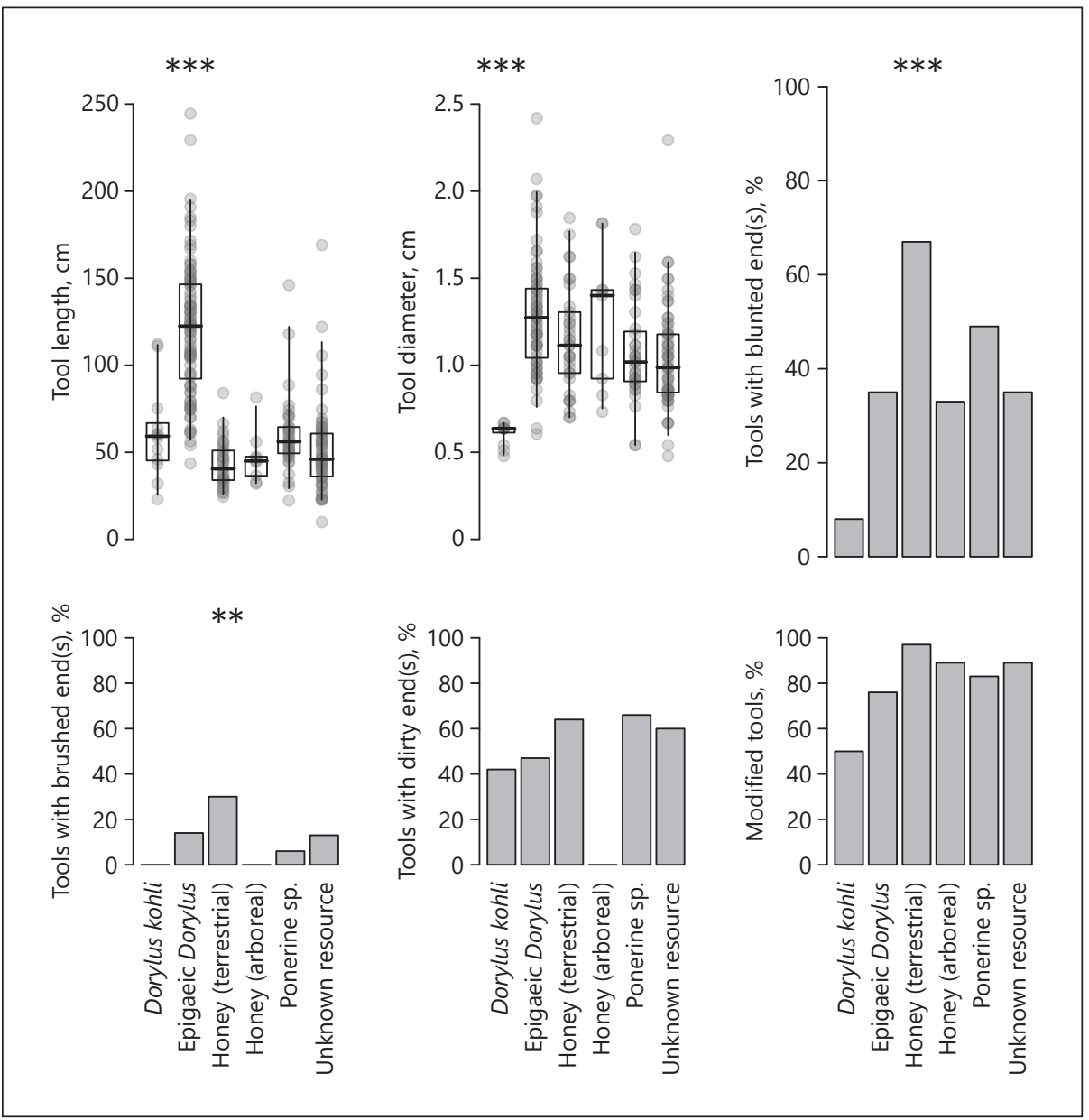

Fig. 4. Comparison of the 5 different Bili-Uéré chimpanzee tool types according to their characteristics. Stars indicate tool types that had significant predictive values for the tool characteristic (see Table 5).

Stingless Bee Arboreal Probes. Similar to ground probes but found lying beneath arboreal beehives, with few signs of wear.

Thin Ant-Dipping Probes or Wands. Thin sticks or herbs with no signs of wear on the ends, not thrust forcefully into the ground and not associated with digging; used to harvest $D$. kohli (online suppl. Materials 12, 13).

Stingless Bee-Digging Sticks. Thick solid sticks thrust into terrestrial beehives, with signs of digging and sometimes associated with excavated honeycomb.

Only 10 out of the 221 individual tools for which these data were recorded still had leaves attached to the non-used end. Six of these were epigaeic driver ant tools (7.6\% of the 79 North Uele long probes), 1 was a D. kohli tool (8.3\% of 12 tools), and 3 were unknown tools. To the south of the Uele River, we never found long probes, 


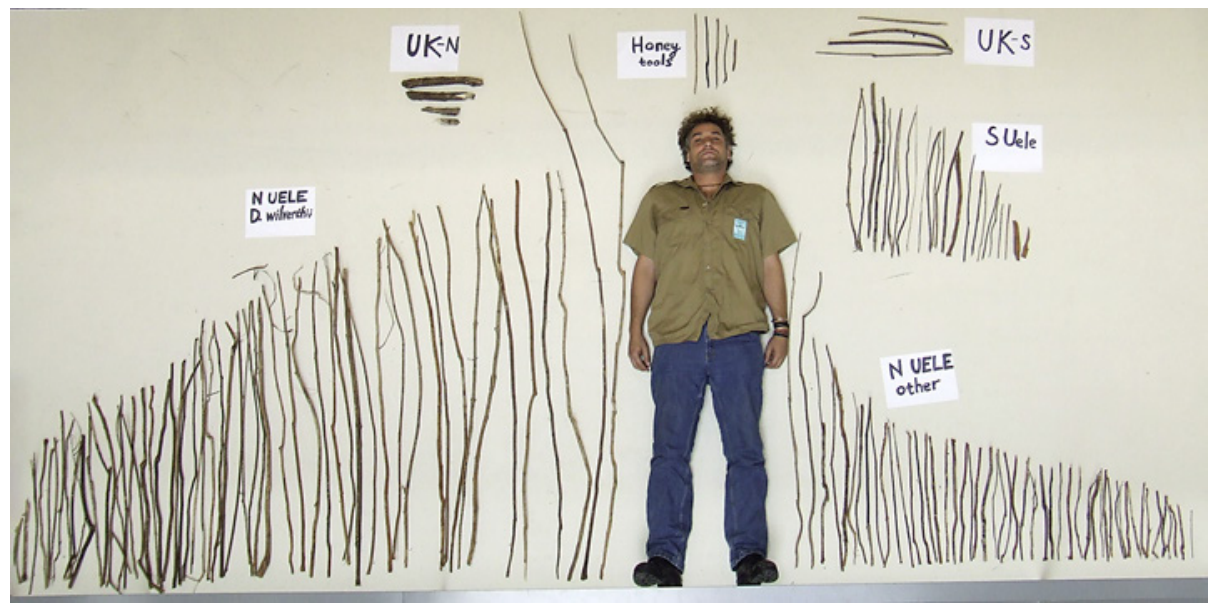

Fig. 5. Insect probes and digging sticks used by chimpanzees found on the Bili-Uéré 2004-2007 surveys, with 1.9-m-tall researcher Jeroen Swinkels included for perspective. The tools to Swinkels' right are a mix of honey-digging sticks, ponerine ant probes and D. kohli wands. The basic pattern is clear: we found long epigaeic Dorylus probes only to the north of the Uele River. All stick tools found to the south of the Uele were short.

Table 5. Results of Generalized Linear Mixed Models testing whether tool characteristics reflected their presumed use

\begin{tabular}{llllllrrr}
\hline Response & Predictor & $\begin{array}{l}\text { Model } \\
\text { family }\end{array}$ & $\begin{array}{l}\text { Tools, } \\
n\end{array}$ & $\begin{array}{l}\text { Sites, } \\
n\end{array}$ & Coeff. & SE & $\begin{array}{c}\chi^{2} \\
\text { value }^{\text {a }}\end{array}$ & $\begin{array}{c}p \\
\text { Tool length }\end{array}$ \\
Tool diameter & Epigaeic Dorylus tool & Gaussian & 177 & 55 & 0.868 & 0.080 & 61.525 & $<0.001$ \\
Brushed end(s) & Terrestrial honey tool & Binomial & 151 & 51 & 1.895 & 0.777 & 6.564 & 0.010 \\
Blunted end(s) & Terrestrial honey tool & Binomial & 142 & 47 & 4.120 & 1.572 & 10.839 & $<0.001$ \\
Dirty & Terrestrial honey tool & Binomial & 142 & 50 & 2.357 & 1.433 & 3.100 & 0.078 \\
Dirty & Ponerine ant tool & Binomial & 142 & 50 & 0.480 & 1.315 & 0.130 & 0.718 \\
\hline
\end{tabular}

We designed the models to test for specific a priori formulated hypotheses about expected length or diameter, or presence of brushed ends, blunted ends or dirt (modification status did not show enough variation for a meaningful analysis). a $\chi^{2}$ values from a likelihood ratio test. $\mathrm{df}$ was 1 in all cases.

which chimpanzees frequently used to prey on epigaeic Dorylus to the north. The two tools found at the only South Uele epigaeic Dorylus site measured only 74.5 and 63.1 $\mathrm{cm}$, which is about half the average length of the northern epigaeic Dorylus tools $(n=86$, mean $=122 \mathrm{~cm}, \mathrm{SD}=38.6)($ Table 6$)$.

We filmed the chimpanzees extracting insects with tools at one D. kohli site (online suppl. Material 12), the apes having prior to the encounter stirred up the earth around the holes, probably using their hands. The other tool sites assigned to D. kohli had similar characteristics: shallow depressions in the ground with the earth churned up, with no visible dirt mounds and usually not found at the base of a tree. We found muddy chimpanzee footprints caked onto vines dangling just above 2 of these pre- 
Table 6. Tool characteristics per tool type of the Bili-Uéré chimpanzees

\begin{tabular}{|c|c|c|c|c|c|c|c|c|c|c|c|c|c|}
\hline Species & $\begin{array}{l}\text { Sites, } \\
n\end{array}$ & $\begin{array}{l}\text { Avg. } \\
\text { tools } \\
\text { per } \\
\text { site, } \\
n\end{array}$ & $\begin{array}{l}\text { Individual } \\
\text { tools, } \\
n\end{array}$ & $\begin{array}{l}\text { Avg. } \\
\text { length, } \\
\mathrm{cm}(n)\end{array}$ & $\mathrm{SD}$ & $\begin{array}{l}\text { Avg. } \\
\text { diameter, } \\
\mathrm{cm}(n)\end{array}$ & $\mathrm{SD}$ & $\begin{array}{l}\text { Modified } \\
\text { out of } \\
\text { total, } \\
\%\end{array}$ & $\begin{array}{l}\text { Blunted } \\
\text { out of } \\
\text { total, } \\
\%\end{array}$ & $\begin{array}{l}\text { Brushed } \\
\text { out of } \\
\text { total, } \\
\%\end{array}$ & $\begin{array}{l}\text { With } \\
\text { leaves } \\
\text { attached } \\
\text { out of } \\
\text { total, \% }\end{array}$ & $\begin{array}{l}\text { Dirty } \\
\text { out of } \\
\text { total, } \\
\%\end{array}$ & $\begin{array}{l}\text { Projecting } \\
\text { from the } \\
\text { ground } \\
\text { out of } \\
\text { total, \% }\end{array}$ \\
\hline $\begin{array}{l}\text { Epigaeic Dorylus } \\
\text { long probes } \\
\text { (North Uele only) }\end{array}$ & 22 & 3.9 & 86 & $\begin{array}{l}122.02 \\
(86)\end{array}$ & 38.63 & $\begin{array}{l}1.29 \\
(70)\end{array}$ & 0.33 & 89.0 & 45.5 & 16.9 & 7.6 & 58.0 & 73.0 \\
\hline $\begin{array}{l}\text { Epigaeic Dorylus } \\
\text { short probes } \\
\text { (South Uele only) }\end{array}$ & 1 & 2.0 & 2 & $\begin{array}{l}68.80 \\
(2)\end{array}$ & 8.06 & $\begin{array}{l}1.02 \\
(2)\end{array}$ & 0.32 & 100.0 & 50.0 & 0 & 0 & 50.0 & 100.0 \\
\hline $\begin{array}{l}\text { Epigaeic Dorylus } \\
\text { probes total }\end{array}$ & 23 & 3.8 & 88 & $\begin{array}{l}120.81 \\
(88)\end{array}$ & 39.02 & $\begin{array}{l}1.28 \\
(72)\end{array}$ & 0.33 & 89.3 & 45.6 & 16.4 & 7.4 & 57.8 & 73.7 \\
\hline $\begin{array}{l}\text { Ponerine probes } \\
\text { North Uele }\end{array}$ & 5 & 3.6 & 18 & $\begin{array}{l}62.57 \\
(18)\end{array}$ & 27.68 & $\begin{array}{l}1.16 \\
(18)\end{array}$ & 0.22 & 94.4 & 88.2 & 11.1 & 0 & 88.9 & 27.8 \\
\hline $\begin{array}{l}\text { Ponerine probes } \\
\text { South Uele }\end{array}$ & 9 & 1.9 & 17 & $\begin{array}{l}57.11 \\
(17)\end{array}$ & 16.20 & $\begin{array}{l}0.98 \\
(17)\end{array}$ & 0.32 & 70.6 & 11.8 & 0 & 0 & 63.6 & 52.9 \\
\hline $\begin{array}{l}\text { Ponerine probes } \\
\text { total }\end{array}$ & 14 & 2.5 & 35 & $\begin{array}{l}59.90 \\
(35)\end{array}$ & 22.68 & $\begin{array}{l}1.07 \\
(35)\end{array}$ & 0.28 & 82.9 & 50.0 & 5.7 & 0 & 79.3 & 40.0 \\
\hline $\begin{array}{l}\text { Stingless bee } \\
\text { arboreal probes }\end{array}$ & 2 & 4.5 & 9 & $\begin{array}{l}46.91 \\
(9)\end{array}$ & 15.09 & $\begin{array}{l}1.27 \\
(9)\end{array}$ & 0.40 & 88.9 & 33.3 & 0 & 0 & 0 & 0 \\
\hline $\begin{array}{l}\text { Honey-digging } \\
\text { sticks }\end{array}$ & 12 & 2.8 & 33 & $\begin{array}{l}43.08 \\
(33)\end{array}$ & 13.42 & $\begin{array}{l}1.15 \\
(35)\end{array}$ & 0.31 & 100 & 84.6 & 37.0 & 0 & 80.8 & 8.0 \\
\hline D. kohli wands & 4 & 3.0 & 12 & $\begin{array}{l}61.39 \\
(12)\end{array}$ & 27.35 & $\begin{array}{l}0.61 \\
(12)\end{array}$ & 0.06 & 85.7 & 20 & 0 & 8.3 & 71.4 & 57.1 \\
\hline $\begin{array}{l}\text { Unknown tools } \\
\text { North Uele }\end{array}$ & 18 & 3.0 & 54 & $\begin{array}{l}52.15 \\
(54)\end{array}$ & 26.42 & $\begin{array}{l}1.03 \\
(52)\end{array}$ & 0.22 & 94.2 & 46.7 & 17.0 & 5.6 & 69.6 & 23.3 \\
\hline $\begin{array}{l}\text { Unknown tools } \\
\text { South Uele }\end{array}$ & 4 & 2.0 & 8 & $\begin{array}{l}42.55 \\
(8)\end{array}$ & 12.46 & $\begin{array}{l}1.22 \\
(8)\end{array}$ & 0.54 & 75 & 14.3 & 0 & 0 & 62.5 & 75 \\
\hline Total unknown tools & 22 & 2.8 & 62 & $\begin{array}{l}50.92 \\
(62)\end{array}$ & 25.20 & $\begin{array}{l}1.05 \\
(59)\end{array}$ & 0.30 & 91.7 & 42.3 & 14.8 & 4.8 & 68.5 & 31.4 \\
\hline
\end{tabular}

avg., average. The columns "average length" and "diameter" include sample size. Rubi-Tele tools are not included here.

dated insect nests, which we did not observe at any other kind of tool site. Camera traps recorded other images of Gangu North chimpanzees using or carrying prepared tools, which appeared to be wands (online suppl. Material 13).

\section{Hole Depth}

In the Camp Louis/Gangu region, epigaeic tool-predated Dorylus holes were significantly deeper (average depth $\pm \mathrm{SD}=66.40 \pm 22.89 \mathrm{~cm}, n=33$ ) than holes made by other kinds of insects $(22.9 \pm 11.8 \mathrm{~cm}, n=24$; Mann-Whitney $\mathrm{U}$ test: $\mathrm{U}=776, p<$ 0.001; online suppl. Material 14). For tools that were found projecting from holes, we measured the depth of insertion of 27 epigaeic Dorylus tools and 20 non-epigaeic Dorylus insect predation tools; the epigaeic ant tools had been thrust in significantly deeper (epigaeic Dorylus ant tools: average depth $=52.4 \mathrm{~cm}, \mathrm{SD}=24.1 \mathrm{~cm}$; "other insect holes": average depth $=22.3 \mathrm{~cm}, \mathrm{SD}=14.0 \mathrm{~cm}$; Mann-Whitney $\mathrm{U}$ test: $\mathrm{U}=$ 464.5, $p<0.001)$.

$\begin{array}{llll} & \text { Folia Primatol 2019;90:3-64 } \\ \text { DOI: } 10.1159 / 000492998 & \text { Hicks et al. }\end{array}$




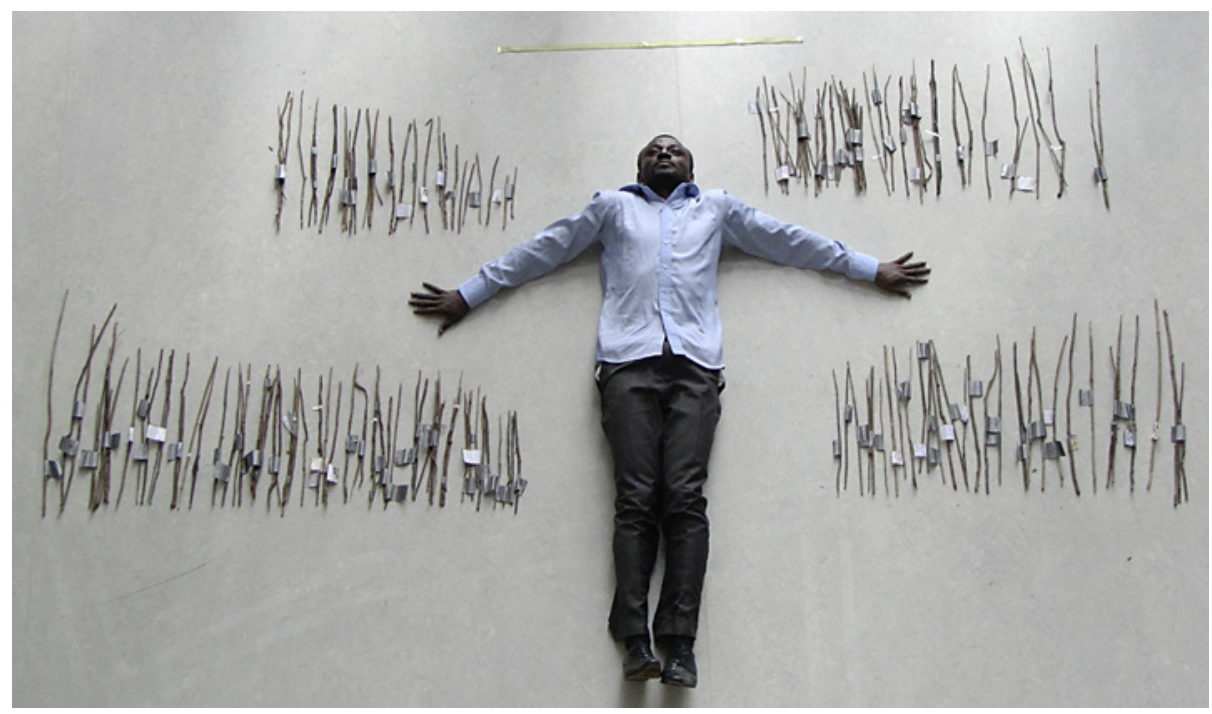

Fig. 6. A.E. Ayamisin ( $1.7 \mathrm{~m}$ tall) with chimpanzee tools collected during the Rubi-Tele study. Conspicuously absent were any long ant probes such as those found to the north of the Uele River (Courtesy PanAf, Max Planck Institute of Evolutionary Anthropology).

\section{Rubi-Tele Tools}

We found no tools on the $66 \mathrm{~km}$ of transects nor on the $22 \mathrm{~km}$ of strip transects. On the $1,000 \mathrm{~km}$ of recces walked, we found 0.17 insect tool sites $/ \mathrm{km}$. None of the tools was longer than $89 \mathrm{~cm}$, and the average length was much shorter (length: $n=$ 166 tools, average length $=40.9 \mathrm{~cm}, \mathrm{SD}=10.1$, range $=16-89 \mathrm{~cm}$; diameter: $n=28$, average diameter $=0.57 \mathrm{~cm}, \mathrm{SD}=0.2 \mathrm{~cm}$, range $=0.3-1 \mathrm{~cm})$ (Fig. 6). Out of the 266 tools found at 170 tool sites, we recorded in the field that 193 of these tools at 102 sites had been used to prey on Ponerinae (known locally as "black ants," as opposed to "red ants," which is the local name for epigaeic Dorylus), although in most of these cases we could not be certain of the type of ant. In 6 cases, T.H. verified from photographs that the tools were associated with ponerine ant nests, and once the researchers photographed the large black ants themselves. None of the photographs of tool sites showed driver ant nests. We found no signs of honey-eating or digging, nor did we find any signs of termite-fishing, despite regular monitoring of Macrotermes mounds.

\section{Geographical Distribution of Tool Types}

We found epigaeic Dorylus tool sites mostly to the north of the Uele River, with long tools for this species recorded only there, whereas ponerine ant dips were overrepresented to the south of the Uele River (Fig. 7; Table 7; online suppl. Material 7). We found honey tools, whether digging sticks or arboreal probes, only to the north of the Uele River. 


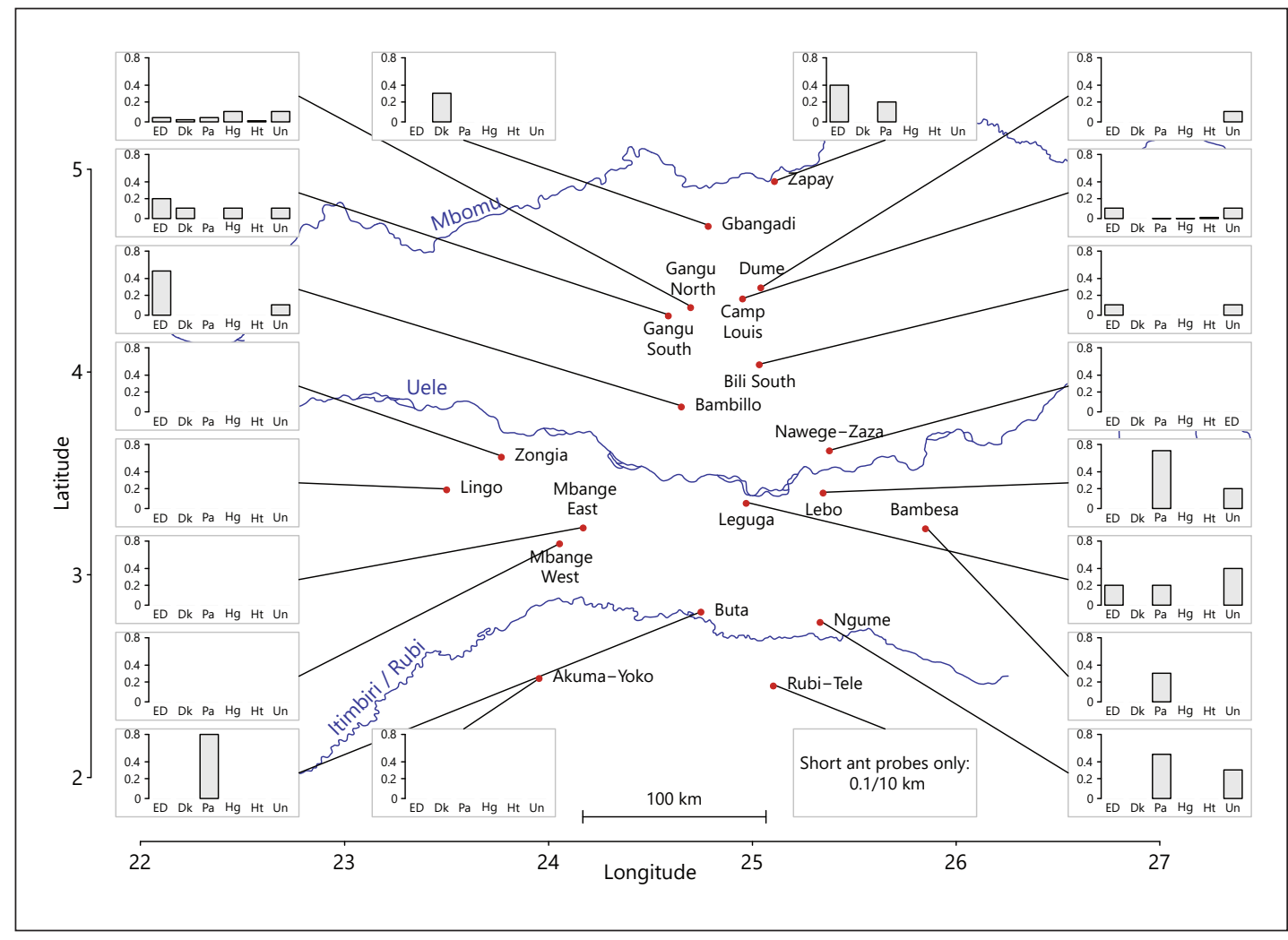

Fig. 7. Map of the distribution and relative frequency of the 5 stick tool types in the 19 study regions (Akuma-Yoko and Nawege-Zaza are combined) and Rubi-Tele. The $y$ axis of each graph depicts the encounter rate (on a log scale) of stick tools per $10 \mathrm{~km}$ walked. Given that we are not certain of the identity of the target species of most of the Rubi-Tele tools, we limit ourselves here to describing them as "short ant probes." Resource types: ED, epigaeic Dorylus; Dk, Dorylus kohli; $\mathrm{Pa}$, ponerine ants; $\mathrm{Hg}$, honey ground; $\mathrm{Ht}$, honey tree; Un, Unknown.

\section{Termite-Fishing Tools and Termite Remains in the Dung}

We checked 168 large awaya forest termite mounds (108 in the Camp LouisGangu region of North Uele and 60 at South Uele sites), which were presumed to be Macrotermes (samples of termites from a few of these mounds were identified by experts as M. muelleri). We found no evidence of Macrotermes consumption (Table 8), despite the ready availability of $M$. muelleri, a species eaten by chimpanzees elsewhere in Africa [McGrew, 1992]. Neither the PanAf team at Gangu North in 2012-2013 nor that at Rubi-Tele to the south of the Uele River found any termite-fishing tools, despite our finding abundant tools at ant mounds and beehives. Nor did we find any Macrotermes (or any other termite remains) in the 2004-2005 or 2012 dung washes (Table 8 ) nor in the Rubi-Tele dung washes, in both dry and wet seasons. 
Table 7. Summary of results on chimpanzee stick tools for 5 resource types at the 20 survey regions and prey availability at the same regions

\begin{tabular}{|c|c|c|c|c|c|c|c|c|c|c|c|c|c|c|c|}
\hline \multirow[t]{2}{*}{ Study site } & \multicolumn{4}{|c|}{$\begin{array}{l}\text { Epigaeic driver ants } \\
\text { (D. wilverthi/terrificus) }\end{array}$} & \multicolumn{3}{|c|}{$\begin{array}{l}\text { Intermediate driver ants } \\
\text { (D. kohli/opacus) }\end{array}$} & \multicolumn{4}{|c|}{ Ponerine ants } & \multicolumn{2}{|c|}{$\begin{array}{l}\text { Underground } \\
\text { honey }\end{array}$} & \multicolumn{2}{|c|}{$\begin{array}{l}\text { Arboreal } \\
\text { honey }\end{array}$} \\
\hline & $\begin{array}{l}\text { insects/ } \\
\mathrm{km}\end{array}$ & $\begin{array}{l}\text { tool } \\
\text { sites/ } \\
\mathrm{km}\end{array}$ & $\begin{array}{l}\text { tools/ } \\
\mathrm{km}\end{array}$ & $\begin{array}{l}\text { dung } \\
\text { washes/ } \\
\text { total }\end{array}$ & $\begin{array}{l}\text { tool } \\
\text { sites/ } \\
\mathrm{km}\end{array}$ & $\begin{array}{l}\text { tools/ } \\
\mathrm{km}\end{array}$ & $\begin{array}{l}\text { dung } \\
\text { washes/ } \\
\text { total }\end{array}$ & $\begin{array}{l}\text { insects/ } \\
\mathrm{km}\end{array}$ & $\begin{array}{l}\text { tool } \\
\text { sites/ } \\
\mathrm{km}\end{array}$ & $\begin{array}{l}\text { tools/ } \\
\mathrm{km}\end{array}$ & $\begin{array}{l}\text { dung } \\
\text { washes/ } \\
\text { total }\end{array}$ & $\begin{array}{l}\text { tool } \\
\text { sites/ } \\
\mathrm{km}\end{array}$ & $\begin{array}{l}\text { tools/ } \\
\mathrm{km}\end{array}$ & $\begin{array}{l}\text { tool } \\
\text { sites/ } \\
\mathrm{km}\end{array}$ & $\begin{array}{l}\text { tools/ } \\
\mathrm{km}\end{array}$ \\
\hline \multicolumn{16}{|l|}{ North Uele } \\
\hline Camp Louis & 0.12 & 0.01 & 0.02 & 0.07 & 0 & 0 & 0 & 0.20 & $<0.01$ & $<0.01$ & 0 & $<0.01$ & $<0.01$ & $<0.01$ & $<0.01$ \\
\hline Gangu North & 0.05 & 0.004 & 0.02 & 0.13 & 0.002 & 0.01 & 0.22 & 0.74 & 0.004 & 0.02 & 0 & $0.01^{1}$ & $0.03^{1}$ & $<0.01$ & 0.01 \\
\hline Gangu South & 0.05 & 0.02 & 0.10 & 0 & 0.01 & 0.02 & 0 & 0.10 & 0 & 0 & 0 & 0.01 & 0.03 & 0 & 0 \\
\hline Bili South & - & 0.01 & 0.02 & - & 0 & 0 & - & - & 0 & 0 & - & 0 & 0 & 0 & 0 \\
\hline Zapay & - & 0.04 & 0.28 & - & 0 & 0 & - & - & 0.02 & 0.04 & - & 0 & 0 & 0 & 0 \\
\hline Gbangadi & - & 0 & 0 & - & 0.03 & 0.16 & - & - & 0 & 0 & - & 0 & 0 & 0 & 0 \\
\hline Dume & - & 0 & 0 & - & 0 & 0 & - & - & 0 & 0 & - & 0 & 0 & 0 & 0 \\
\hline Bambillo & - & 0.05 & 0.21 & - & 0 & 0 & - & - & 0 & 0 & - & 0 & 0 & 0 & 0 \\
\hline Nawege-Zaza & - & 0 & 0 & - & 0 & 0 & - & - & 0 & 0 & - & 0 & 0 & 0 & 0 \\
\hline \multicolumn{16}{|l|}{ South Uele } \\
\hline Lingo & 0.13 & 0 & 0 & - & 0 & 0 & - & 0 & 0 & 0 & - & 0 & 0 & 0 & 0 \\
\hline Zongia & 0.08 & 0 & 0 & - & 0 & 0 & - & 0.11 & 0 & 0 & - & 0 & 0 & 0 & 0 \\
\hline Mbange East & 0.05 & 0 & 0 & - & 0 & 0 & - & 0.03 & 0 & 0 & - & 0 & 0 & 0 & 0 \\
\hline Mbange West & 0 & 0 & 0 & - & 0 & 0 & 0 & 0.02 & 0 & 0 & - & 0 & 0 & 0 & 0 \\
\hline Lebo & - & 0 & 0 & - & 0 & 0 & - & - & 0.07 & 0.19 & - & 0 & 0 & 0 & 0 \\
\hline Leguga & 0.02 & 0.02 & 0.04 & - & 0 & 0 & - & 0.07 & 0.02 & 0.06 & - & 0 & 0 & 0 & 0 \\
\hline Bambesa & 0.03 & 0 & 0 & - & 0 & 0 & - & 0.22 & $0.03^{2}$ & $0.03^{2}$ & - & 0 & 0 & 0 & 0 \\
\hline Akuma-Yoko & 0.05 & 0 & 0 & - & 0 & 0 & $\begin{array}{l}\text { found } \\
\text { once }\end{array}$ & 0 & 0 & 0 & - & 0 & 0 & 0 & 0 \\
\hline Buta & 0 & 0 & 0 & - & 0 & 0 & - & 0.16 & 0.08 & 0.12 & - & 0 & 0 & 0 & 0 \\
\hline Ngume & 0.05 & 0 & 0 & - & 0 & 0 & - & 0.24 & 0.05 & 0.05 & - & 0 & 0 & 0 & 0 \\
\hline Rubi-Tele & 0.02 & 0 & 0 & 0.04 & 0 & 0 & 0.01 & 0.003 & $0.10^{3}$ & $0.19^{3}$ & 0.01 & 0 & 0 & 0 & 0 \\
\hline
\end{tabular}

The "dung washes" columns indicate the proportion of dung samples containing the resource, while all other columns represent encounter rates per kilometre walked. "Insects/km" refers to encounters with insects or their nests. -, no survey data. If a column under the heading "dung" was not included for an insect, then we found no samples in any of the dung washes. We also found weaver ants (Oecophylla) in one Gangu North dung sample in addition to finding a nest full of these ants which had been crushed by a chimpanzee. We found no termite or bee samples in any of the dung washes, nor did we find any termite tools. We found one sample of D. kohli in chimpanzee dung at Akuma, one at a chimpanzee tool site at Gangu South, and we counted one swarm of these ants on a transect in Gangu South (thus an encounter rate of $0.05 / \mathrm{km}$ ). ${ }^{1}$ Does not include honey tool sites NBC1 and NBC2 as we did not find these during recce walks. ${ }^{2}$ Includes a ponerine "ant scoop" made of bark. ${ }^{3}$ We recorded these as "black ant" sites, and in 6 cases we could confirm this from photographs of the nests. Given that we encountered epigaeic Dorylus ants in the dung, however, we cannot rule out that some of these sites may have belonged to this ant type. Another 73 potential stick tools at 68 sites were not classified as "black ant," and the resource they targeted was unknown.

\section{Effects of Habitat Type and Forest Density on Tool Site Encounter Rates}

In the main survey regions, we most frequently found 4 of the 5 tool types in mixed forest habitat, and we found 1 of the 2 stingless bee arboreal probe sites there as well (Fig. 8a). We can note some habitat differences. We found $20 \%$ of the epigaeic Dorylus tool sites and 1 of the 2 honey tree probe sites in savanna-associated habitat but none of the other tool types. We found $7 \%$ of ponerine ant tools and $17 \%$ of honey ground tool sites in mono-dominant Gilbertiodendron forest, usually along the edges of streams, where other tool types were lacking. We found $17 \%$ of the terrestrial honey tool sites in hillside mixed forest (not shown in Fig. $8 \mathrm{a}$ ), and $14 \%$ of ponerine ant tool sites in herb patches, where other tool types were lacking. As for forest density, D. kohli and ponerine ant tool sites were fairly evenly distributed between closed, medium-density and open forest. We found epigaeic Dorylus sites mostly in medium density forest (possibly due to the association of these ants with more open savanna habitats). We found honey ground sites 
Table 8. Summary of Macrotermes availability and tool use, as well as pounding sites and resource availability, at the 20 survey regions

\begin{tabular}{|c|c|c|c|c|c|c|c|c|c|c|c|c|}
\hline \multirow[t]{2}{*}{ Study site } & \multicolumn{4}{|c|}{ Macrotermes } & \multicolumn{3}{|c|}{ Cubitermes/T. macrothorax } & \multicolumn{2}{|c|}{ African giant snails } & \multicolumn{2}{|c|}{ Fruit pound } & \multirow{2}{*}{$\begin{array}{l}\begin{array}{l}\text { Tortoise } \\
\text { pound }\end{array} \\
\text { pounded } \\
\text { tortoise/ } \\
\mathrm{km}\end{array}$} \\
\hline & $\begin{array}{l}\text { mounds/ } \\
\mathrm{km}\end{array}$ & $\begin{array}{l}\text { swarms/ } \\
\mathrm{km}\end{array}$ & $\begin{array}{l}\text { tool or } \\
\text { pounding } \\
\text { sites } / \mathrm{km}\end{array}$ & $\begin{array}{l}\text { dung } \\
\text { washes/ } \\
\text { total }\end{array}$ & $\begin{array}{l}\text { mounds/ } \\
\mathrm{km}\end{array}$ & $\begin{array}{l}\text { pounding } \\
\text { sites/km }\end{array}$ & $\begin{array}{l}\text { pounded } \\
\text { mounds/ } \\
\mathrm{km}\end{array}$ & $\begin{array}{l}\text { pounding } \\
\text { sites/km }\end{array}$ & $\begin{array}{l}\text { pounded } \\
\text { snails/ } \\
\mathrm{km}\end{array}$ & $\begin{array}{l}\text { pounded } \\
\text { fruit } \\
\text { sites } / \mathrm{km}\end{array}$ & $\begin{array}{l}\text { pounded } \\
\text { fruit/ } \\
\mathrm{km}\end{array}$ & \\
\hline \multicolumn{13}{|l|}{ North Uele } \\
\hline Camp Louis & 0.48 & 0.09 & 0 & 0 & $\begin{array}{l}36.8 \\
\text { comb. }\end{array}$ & 0.01 & 0.01 & 0.002 & 0.004 & $<0.01$ & 0.004 & $<0.01$ \\
\hline Gangu North & 1.28 & 0.14 & 0 & 0 & $\begin{array}{l}34.5 \\
\text { comb. }^{1}\end{array}$ & 0.02 & 0.03 & 0.03 & 0.06 & 0.03 & 0.15 & 0 \\
\hline Gangu South & 3.85 & 0 & 0 & 0 & 37 comb. & 0 & 0 & 0.01 & 0.01 & 0 & 0 & 0 \\
\hline Bili South & - & - & 0 & - & - & 0.04 & 0.06 & 0.03 & 0.06 & 0 & 0 & 0 \\
\hline Zapay & - & - & 0 & - & - & 0 & 0 & 0.06 & 0.12 & 0 & 0 & 0 \\
\hline Gbangadi & - & - & 0 & - & - & 0.16 & 0.19 & 0.06 & 0.13 & 0.03 & 0.13 & 0 \\
\hline Dume & - & - & 0 & - & - & 0 & 0 & 0.09 & 0.28 & 0 & 0 & 0 \\
\hline Bambillo & - & - & 0 & - & - & 0 & 0 & 0.08 & 0.22 & 0 & 0 & 0 \\
\hline Nawege-Zaza & - & - & 0 & - & - & 0.05 & 0.05 & 0.09 & 0.37 & 0 & 0 & 0 \\
\hline \multicolumn{13}{|l|}{ South Uele } \\
\hline Lingo & 0.03 & - & 0 & - & - & 0.05 & 0.10 & 0.21 & 0.70 & 0 & 0 & 0 \\
\hline Zongia & 0.17 & - & 0 & - & - & 0.06 & 0.06 & 0.20 & 0.56 & 0 & 0 & 0 \\
\hline Mbange East & 0.05 & - & 0 & - & - & 0.07 & 0.11 & 0.06 & 0.14 & 0 & 0 & 0 \\
\hline Mbange West & 0.20 & - & 0 & - & - & 0.04 & 0.07 & 0.13 & 0.31 & 0 & 0 & 0 \\
\hline Lebo & - & - & 0 & - & - & 0.2 & 0.2 & 0.17 & 0.41 & 0 & 0 & 0 \\
\hline Leguga & 0.28 & - & 0 & - & - & 0.06 & 0.19 & 0.72 & 1.36 & 0 & 0 & 0.02 \\
\hline Bambesa & 0.12 & - & 0 & - & - & 0.02 & 0.02 & 0.39 & 0.68 & 0 & 0 & 0 \\
\hline Akuma-Yoko & 0.31 & - & 0 & - & - & 0.22 & 0.27 & 0.27 & 0.49 & 0 & 0 & 0 \\
\hline Buta & 0.04 & - & 0 & - & - & 0 & 0 & 0.08 & 0.43 & 0 & 0 & 0 \\
\hline Ngume & 0.19 & - & 0 & - & - & 0.11 & 0.16 & 0.29 & 0.43 & 0 & 0 & 0 \\
\hline Rubi-Tele & 0.01 & - & 0 & 0 & 0.01 & 0.01 & 0.02 & 0.01 & 0.01 & 0 & 0 & 0 \\
\hline
\end{tabular}

The "dung washes" columns indicate the proportion of dung samples containing the resource, while all other columns represent encounter rates per kilometre walked; comb., combined; -, no survey data. ${ }^{1}$ Cubitermes mound encounter rates alone: 58 mounds found over $2 \mathrm{~km}$ walked in Gangu North, in 2012: 29/km. T. macrothorax mound encounter rates alone: 11 mounds found over $2 \mathrm{~km}$ walked in Gangu North, in 2012: 5.5/km. We did not include in this total Cubitermes and Thoracotermes mounds that appeared to have been pounded by chimpanzees against the ground without a substrate. Some of the snailpounding sites were almost certainly made my marsh mongooses and others most likely by chimpanzees.

mostly in open or medium density forest and the two honey tree sites in medium and dense forest (Fig. 8b).

\section{Insect Availability}

Ponerine and epigaeic Dorylus ants as well as Macrotermes, Cubitermes and T. macrothorax mounds were present across the study region (Tables 7, 8; suppl. Material 5). Encounter rates varied substantially between sites.

\section{Tool Plant Species}

At the 19 main survey sites, the chimpanzees used a wide diversity of plant species to make each of the tool types, especially for epigaeic Dorylus tools (Fig. 9; online suppl. Material 15). Counting only tools for which the source plant was identified, the chimpanzees used 29 plant species to make 54 epigaeic Dorylus tools, 6 to make 9 D. kohli tools, 13 to make 22 ponerine ant tools, 9 to make 21 honey-digging tools and 2 to make 4 arboreal honey probes. The chimpanzees used 8 of the 29 plant species

$\begin{array}{llll} & \text { Folia Primatol 2019;90:3-64 } & \text { Hicks et al. } \\ \text { DOI: } 10.1159 / 000492998 & \end{array}$




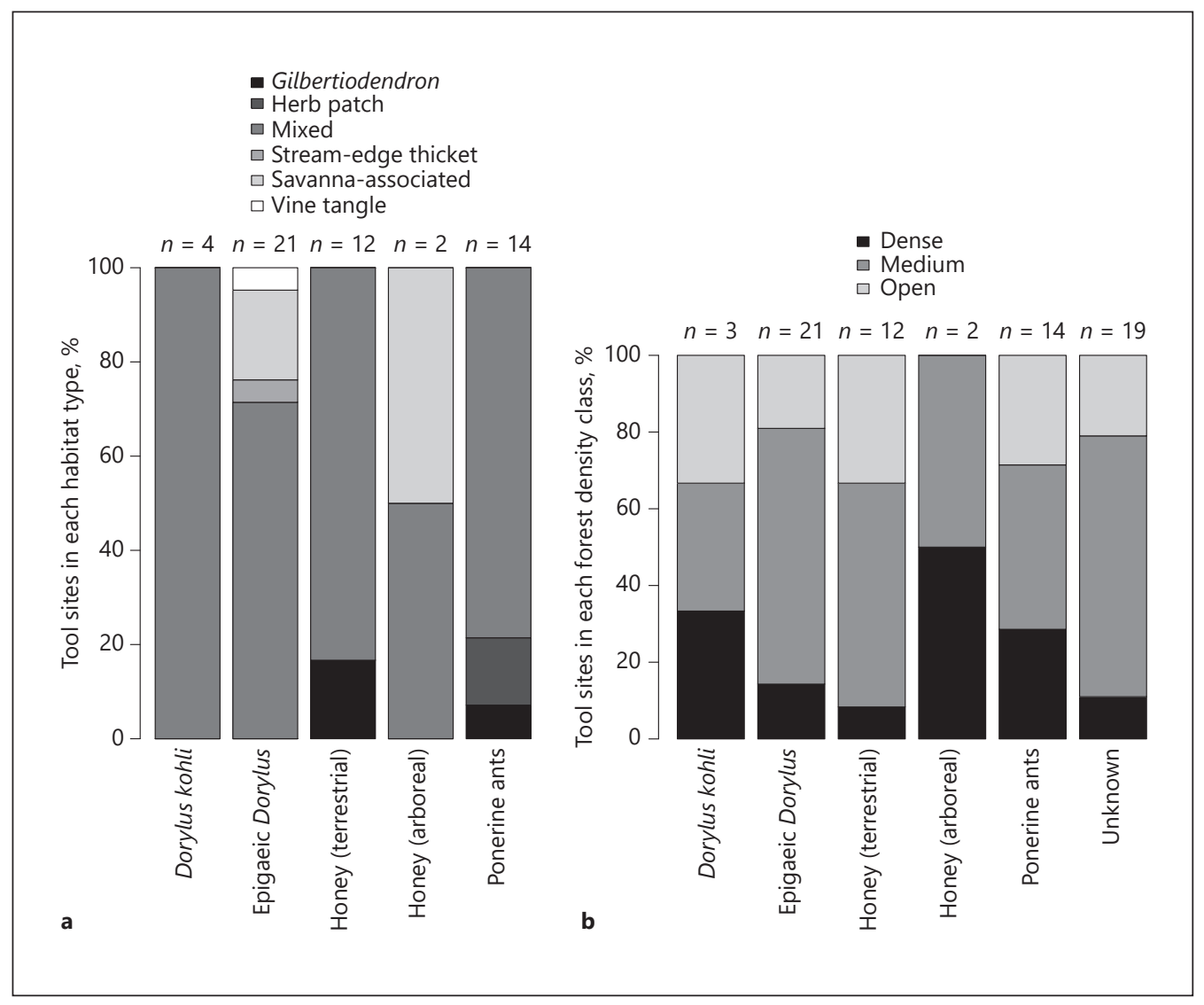

Fig. 8. Impact of forest type on distribution of tool types. a Percentages of tool sites per tool type found in different habitat types. Unknown tools were not included. b Percentages of tool sites per tool type found in different forest densities.

(28\%) used for epigaeic Dorylus tools for other tool types as well, and this applied also to 7 out of $13(54 \%)$ of the ponerine ant tool sources, $100 \%$ of the arboreal honey probe sources, 8 out of 9 (89\%) of the honey-digging stick sources, and 3 out of 6 of the D. kohli sources.

\section{Other Chimpanzee Tool Types and Related Insect Predation Behaviour}

\section{Ant Scoop}

In April 2008, at a site in the Bambesa Forest (N 3²1.115', E $\left.25^{\circ} 50.134^{\prime}\right)$, T.H. and team found a $20.1 \times 5 \mathrm{~cm}$ scoop-shaped section of bark lying atop an active, partially excavated $M$. analis mound. The bark scoop had been ripped from a log $3 \mathrm{~m}$ south-east, and the pieces matched perfectly when compared. Within $10 \mathrm{~cm}$ of the tool, we found a fresh chimpanzee footprint in the ant mound, along with fresh chim- 


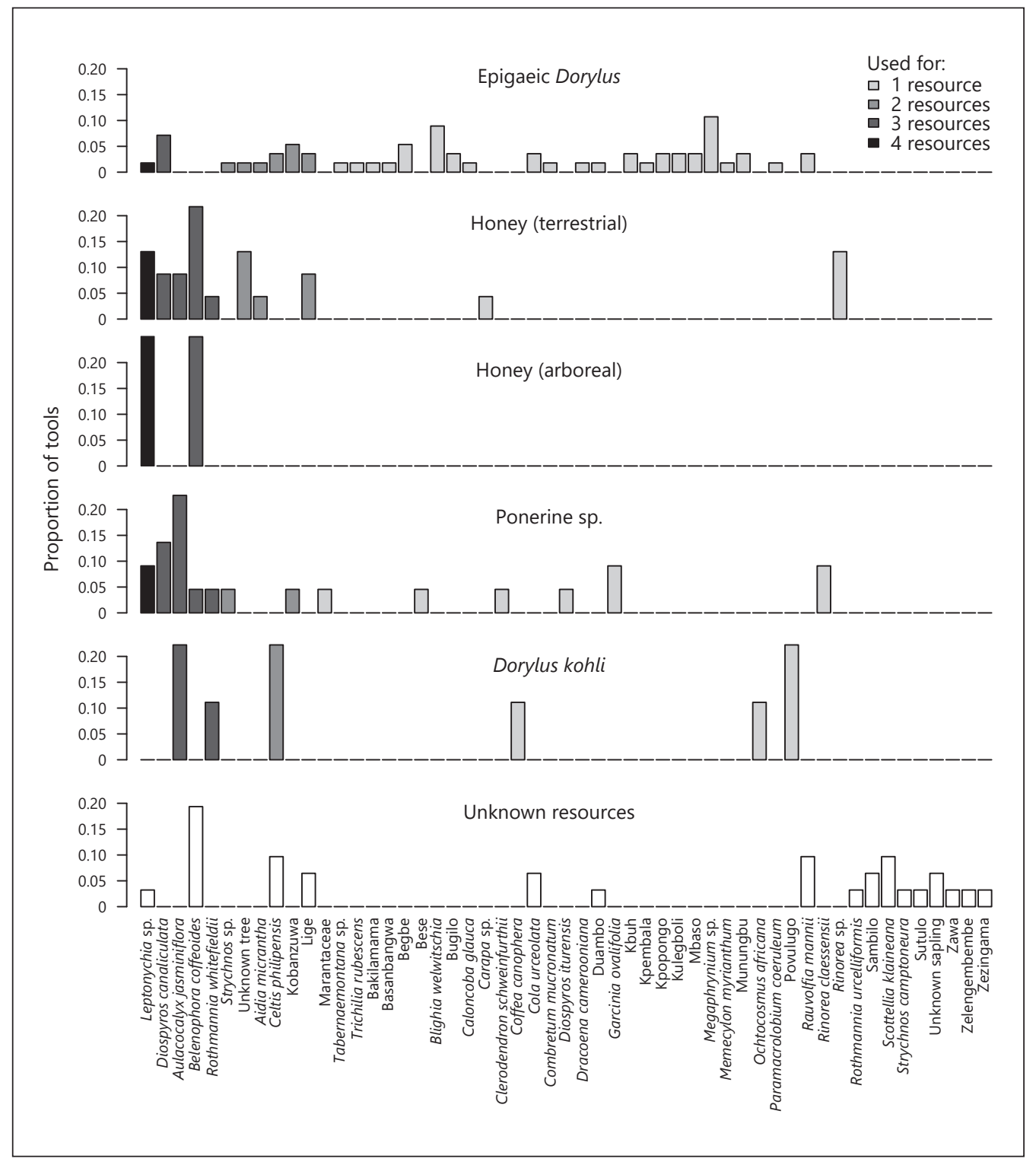

Fig. 9. Plant species used to make the 5 different types of chimpanzee tools in northern DRC.

panzee feeding remains and another footprint within $50 \mathrm{~m}$. Dirt excavated from the ant mound was caked $9.5 \mathrm{~cm}$ along the inner surface of the tool, indicating that it had been used to scoop mud out of the ant hole to access the ants (see Appendices: Fig. A13a, b). All other tools found at ponerine ant nests in the area had been standard ant dip tools. This ant scoop is apparently a new form of tool use not documented in other chimpanzee populations. 
Table 9. Encounter rates (number $/ \mathrm{km}$ ) of non-tool artefacts per survey region

\begin{tabular}{|c|c|c|c|c|c|c|c|c|c|c|c|}
\hline & Time period & $\begin{array}{l}\text { Kilometres } \\
\text { walked } \\
\text { per } \\
\text { region }\end{array}$ & $\begin{array}{l}\text { Termite } \\
\text { mound- } \\
\text { pounding } \\
\text { sites }\end{array}$ & $\begin{array}{l}\text { Pounded } \\
\text { termite } \\
\text { mounds }\end{array}$ & $\begin{array}{l}\text { Snail- } \\
\text { pounding } \\
\text { sites }\end{array}$ & $\begin{array}{l}\text { Pounded } \\
\text { snails }\end{array}$ & $\begin{array}{l}\text { Pounded } \\
\text { tortoises }\end{array}$ & $\begin{array}{l}\text { Fruit- } \\
\text { pounding } \\
\text { sites }\end{array}$ & $\begin{array}{l}\text { Pounded } \\
\text { fruits }\end{array}$ & $\begin{array}{l}\text { Soil } \\
\text { dig } \\
\text { sites }\end{array}$ & $\begin{array}{l}\text { Weaver } \\
\text { ant } \\
\text { nestcrush } \\
\text { sites }\end{array}$ \\
\hline Camp Louis & Aug 04 to Mar 13 & $1,430.6$ & 0.01 & 0.01 & 0.002 & 0.004 & $<0.001$ & $<0.001$ & 0.004 & $<0.001$ & 0 \\
\hline Dume & Aug to Sept 12 & 93.6 & 0 & 0 & 0.09 & 0.28 & 0 & 0 & 0 & 0 & 0 \\
\hline Gangu North & Mar 05 to Mar 13 & 813.5 & 0.02 & 0.03 & 0.03 & 0.06 & 0 & 0.03 & 0.14 & 0.001 & 0.001 \\
\hline Gangu South & June 05 to Nov 13 & 135.9 & 0 & 0 & 0.07 & 0.07 & 0 & 0 & 0 & 0 & 0 \\
\hline Bili South & Jul 06 to Nov 06 & 205.2 & 0.04 & 0.06 & 0.03 & 0.06 & 0 & 0 & 0 & 0.03 & 0 \\
\hline Zapay & Dec 06 & 49.9 & 0 & 0 & 0.06 & 0.12 & 0 & 0 & 0 & 0.02 & 0 \\
\hline Bambillo & Oct to Nov 12 & 76.2 & 0 & 0 & 0.08 & 0.22 & 0 & 0 & 0 & 0 & 0 \\
\hline Gbangadi & Dec 06 & 31.7 & 0.16 & 0.19 & 0.06 & 0.13 & 0 & 0.03 & 0.13 & 0 & 0 \\
\hline Nawege-Zaza & Sept 06 , Aug 08 & 21.7 & 0.05 & 0.05 & 0.09 & 0.34 & 0 & 0 & 0 & 0 & 0 \\
\hline Lebo & Sept 06 , Aug 08 & 41.3 & 0.02 & 0.02 & 0.17 & 0.41 & 0 & 0 & 0 & 0.02 & 0 \\
\hline Bambesa & Apr to May 08 & 64.9 & 0.02 & 0.02 & 0.39 & 0.68 & 0 & 0 & 0 & 0.03 & 0 \\
\hline Leguga & Mar 08 & 48.5 & 0.06 & 0.19 & 0.72 & 1.36 & 0.02 & 0 & 0 & 0.02 & 0 \\
\hline Buta & Sept to Oct 08 & 25.6 & 0 & 0 & 0.08 & 0.43 & 0 & 0 & 0 & 0 & 0 \\
\hline Ngume & Oct 08 & 37.5 & 0.11 & 0.16 & 0.29 & 0.43 & 0 & 0 & 0 & 0 & 0 \\
\hline Akuma-Yoko & Jun 08 to Nov 08 & 22.4 & 0.22 & 0.27 & 0.27 & 0.49 & 0 & 0 & 0 & 0.09 & 0 \\
\hline Mbange East & Jan 08 & 80.9 & 0.07 & 0.11 & 0.06 & 0.14 & 0 & 0 & 0 & 0.01 & 0 \\
\hline Mbange West & Jan 08 to Feb 08 & 45.5 & 0.04 & 0.07 & 0.13 & 0.31 & 0 & 0 & 0 & 0 & 0 \\
\hline Lingo & Nov 08 & 38.5 & 0.05 & 0.10 & 0.21 & 0.70 & 0 & 0 & 0 & 0 & 0 \\
\hline Zongia & Nov 08 & 35.7 & 0.06 & 0.06 & 0.19 & 0.56 & 0 & 0 & 0 & 0 & 0 \\
\hline $\begin{array}{l}\text { North of Uele } \\
\text { total }\end{array}$ & Aug 04 to Mar 13 & $2,858.2$ & 0.02 & 0.02 & 0.02 & 0.04 & $<0.001$ & 0.01 & 0.05 & 0.003 & $<0.001$ \\
\hline $\begin{array}{l}\text { South of Uele } \\
\text { total }\end{array}$ & $\begin{array}{l}\text { Sept } 06 \text {, Nov } 07 \text { to } \\
\text { Feb } 09\end{array}$ & 440.9 & 0.06 & 0.09 & 0.25 & 0.54 & 0.002 & 0 & 0 & 0.02 & 0 \\
\hline Total surveys & Aug 04 to Mar 13 & 3,299 & 0.02 & 0.03 & 0.05 & 0.11 & $<0.001$ & 0.01 & 0.04 & 0.005 & $<0.001$ \\
\hline Rubi-Tele & 2014 to 2016 & 1,066 & 0.01 & 0.02 & 0.009 & 0.01 & 0 & 0 & 0 & 0 & 0 \\
\hline
\end{tabular}

We omitted from this table termite mound sites which were apparently pounded against the ground, not a substrate. We counted snail-pounding sites only if we found cracked shells within $<10 \mathrm{~m}$ of a bruised tree or root (see online suppl. Material 16).

\section{Weaver Ant Crush}

The consumption of weaver ants, which has been recorded at the majority of long-term chimpanzee study sites and can be considered a form of container use [Goodall, 1986; McGrew, 1992], was present both north and south of the Uele River (Table 9, online suppl. Material 2, 16). In January 2007, in the Gangu Forest, while following a trail of fresh chimpanzee feeding remains, T.H. observed the remains of a weaver ant $(O$. longinoda) nest still swarming with ants that had just been pulled

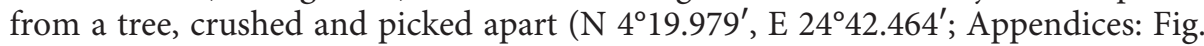
A14). On the crumpled leaves, he found the remains of crushed ants.

\section{Soil-Digging Behaviour}

At a number of sites, we found evidence for soil-digging behaviour, evidenced by digging marks in the soil left by chimpanzees, in which we could see insects crawling. We do not know whether the chimpanzees consumed these insects (Table 9, online suppl. Material 16).

\section{Percussive Technology}

We documented the pounding of food resources upon substrates, which we consider a form of percussive technology; in most cases in our study, this did not involve the use of tools (Table 9; online suppl. Material 16). Percussive technology can be 


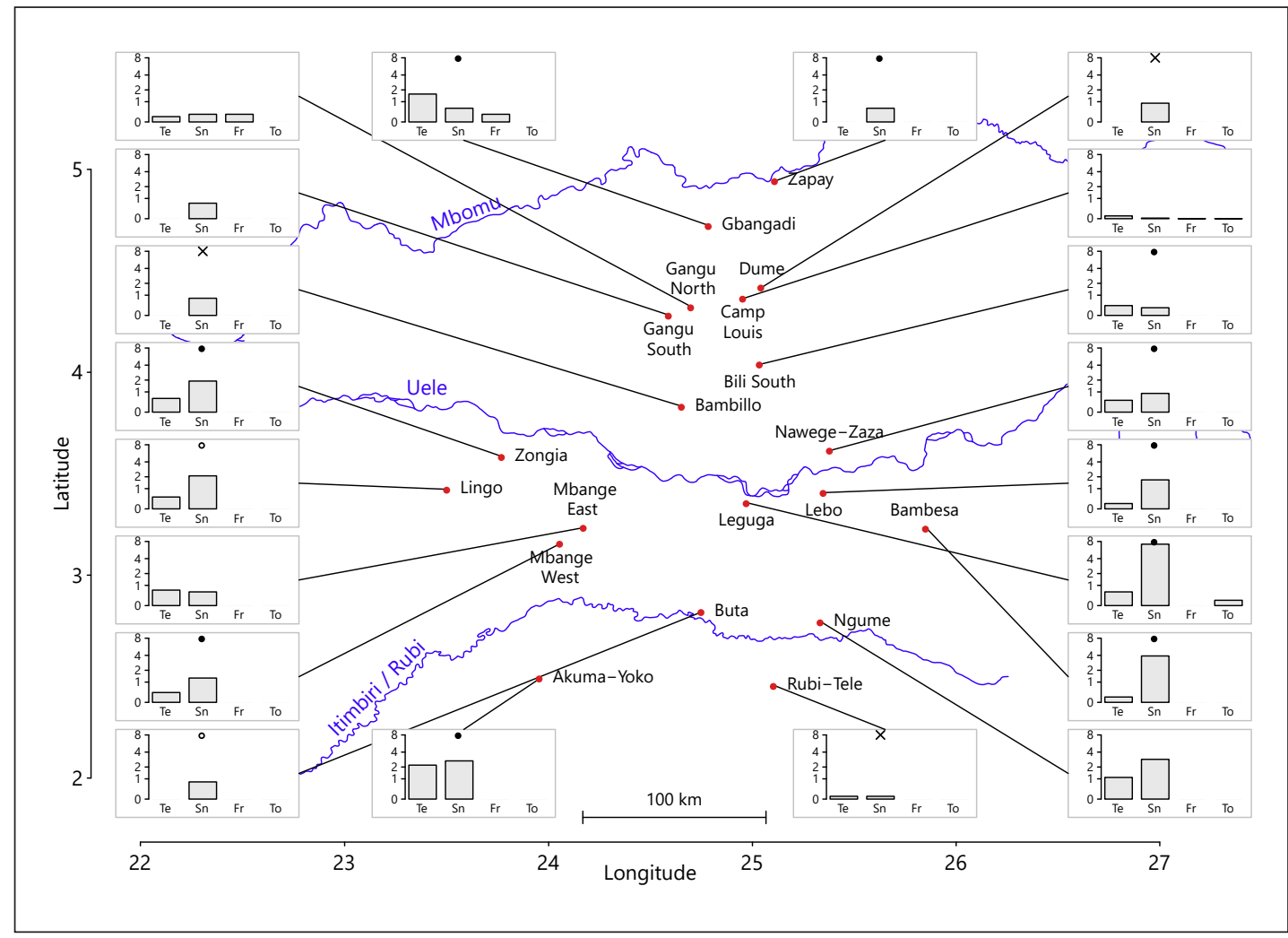

Fig. 10. Encounter rates of termite mound-, snail-, fruit-, and tortoise-pounding sites per $10 \mathrm{~km}$ walked at the 19 main study regions and Rubi-Tele. Circles above the "snail pound" column indicate whether one or more snail-pounding sites were found near chimpanzee evidence: open circle, chimpanzee evidence within $50 \mathrm{~m}$ of site; filled circle, chimpanzee evidence within $10 \mathrm{~m}$ of site; no circle, no chimpanzee evidence found near snail-pounding sites; $\times$, data not recorded. Resource types: Te, termites (Cubitermes and Thoracotermes); Sn, African giant snail; Fr, fruit; To, tortoise (Kinixys sp.).

defined as the application of forceful strikes of one solid body against another as a means to achieve an end, and can be seen as a precursor of hammer tools. The use of percussive technology is widespread in chimpanzee populations, although it is usually limited to one type of food, typically fruits [c.f. Marchant and McGrew, 2005; Koops et al. 2010]. Figure 10 shows pounding site encounter rates at each of the 19 study sites and Rubi-Tele.

\section{Fruit Hammer Pounding Tool}

In March 2008, we discovered a chimpanzee "workshop" and contact site in the Leguga Forest (N 322.080', E 24 ${ }^{\circ} 57.913^{\prime}$ [Hicks, 2010]). Within $7 \mathrm{~cm}$ of one of the many chimpanzee-pounded termite mounds and in association with fresh chimpanzee dung, feeding remains, leaf cushions and ground nests, we found a Desplatsia dewevrei fruit which had apparently been used as a hammer to pulverize a termite 
mound (probably Cubitermes). The fruit was deeply bruised, and dirt from the termite mound was embedded in its skin. From its position, the fruit appeared to have been used to hammer the termite mound and not the other way around (see Appendices: Fig. A15a, b). D. dewevrei was a common chimpanzee food both north and south of the Uele River [Hicks, 2010], but this was the only case in which a chimpanzee appeared to have used one as a tool. We consider this a form of percussive technology. We saw no evidence of stick or stone hammers at any of our survey sites.

\section{Termite Mound Pounding against a Substrate}

Main Survey Regions

At nearly all of the 19 survey regions, we found numerous termite mounds that had been pounded open against substrates, and in a few cases apparently against the ground (Appendices: Fig. A16a-e). We also on 3 occasions confirmed termite moundpounding directly: twice in the Camp Louis Forest and once in the Leguga Forest. As we approached and observed noisy groups of chimpanzees, we could hear the loud repetitive sounds of an object being thumped against a substrate, in each case beneath a tree-full of chimpanzees. On March 19, 2008, at a chimpanzee "workshop" in the Leguga Forest (Hicks, 2010), a few minutes after hearing the rhythmic thumping of a large mound being pounded open and while in the process of examining its remains, we observed an adult male chimpanzee pulling a second large T. macrothorax mound off the side of a tree before he saw us and fled (N 3 $22.107^{\prime}$, E 24 $57.926^{\prime}$ ) (see online suppl. Material 17 for descriptions of 2 additional cases). North of the Uele River, experts confirmed that 2 of the pounded mounds we found belonged to the genus Cubitermes, while others (based on their size and shape) belonged to the closely related $T$. macrothorax. South of the Uele, experts confirmed that at least 3 of the larger mounds pounded open belonged to T. macrothorax, although the smaller, mushroom-shaped Cubitermes was pounded open there as well. Overall, we found 1.3 smashed termite mounds per pounding site (South Uele: 1.4; North Uele: 1.2) (online suppl. Material $18)$. Roots $(n=52)$ were the most common substrate, but tree bases (7) and buttresses (10) were frequently used as well; north of the Uele, rocks served as substrates 8 times. Of the 83 definite termite mound-pounding sites for which age of site was recorded, 67 appeared to be at most 1 week old based on crispness of broken edges, freshness of buttress bruises and/or presence of exposed living larvae and alates. We found the majority of mounds (62\%) in medium density forest, and $24 \%$ in riverine forest. A seasonal trend may exist in the occurrence of freshly smashed termite mounds (Fig. 11; online suppl. Material 19). The chimpanzees appeared to pound fewer mounds during the dry season; the behaviour peaked at the end of March and the beginning of April with the onset of rains, and then declined as the rainy season progressed, disappearing completely at the peak of the dry season in February.

By fitting the fragmented mounds against the remains of nearby mound bases, we were able to locate the sources from which 34 of the pounded termite mounds had been ripped. The average distance between these sources and the pounding substrates was $3.77 \mathrm{~m}$ (SD $=10.1$, median $=1.42 \mathrm{~m}$, quartiles: 0.50 and 3.0). Six of these sources were located further than $4 \mathrm{~m}$ from the pounding site; one of these was a $60 \mathrm{~m}$ distant termite mound from which a chunk had been broken off and carried through dense forest to the pounding site. Four of the 93 pounded termite mounds ( 2 to the north of the Uele and 2 to the south) were heavy and bulky enough that they likely would have required bipedalism: the first author, a 2.1-m-tall biped, had considerable difficulty carrying 
Fig. 11. Seasonality in the termite mound-pounding behaviour of the Bili-Uéré chimpanzees.

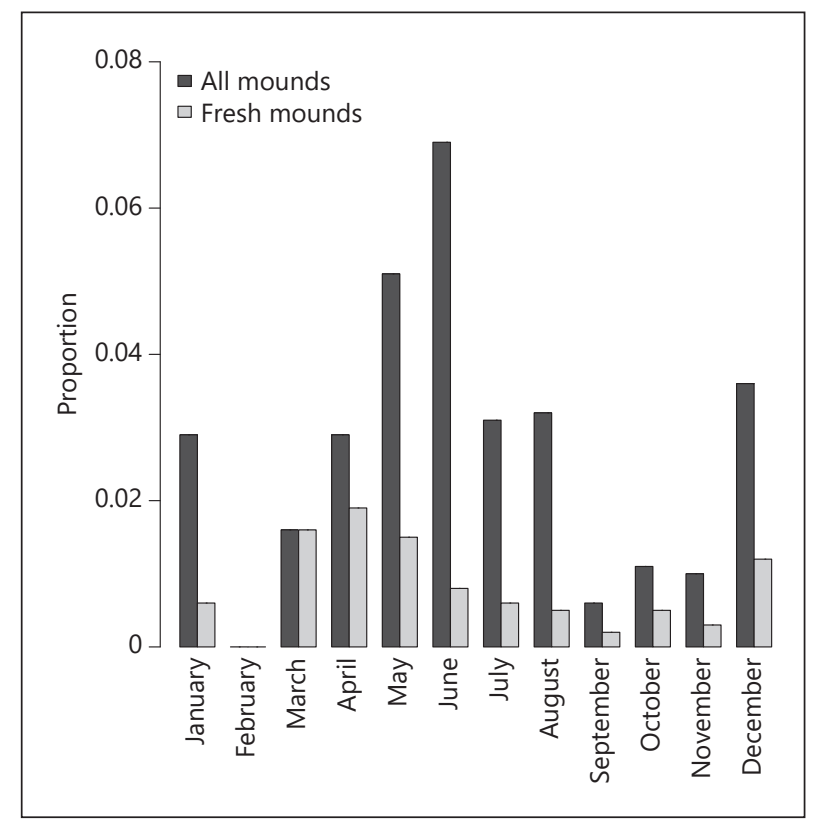

them and had to use both hands (they were found $0.5,0.9,3$ and $5.2 \mathrm{~m}$ from their sources, respectively) (Appendices: Fig. A16e). Although we cannot rule out that the mounds might have been rolled to the anvils, this is unlikely, because at fresh sites we could detect no signs of disturbance from the passage of a large dirt mound over the ground.

Rubi-Tele

We found 22 termite mounds (Cubitermes sp. or T. macrothorax) which had been pounded open at 12 pounding sites. The chimpanzees had used roots or rocks as a substrate.

\section{Fruit Pounding}

In the Bili-Gangu and Gbangadi forests north of the Uele, we found abundant piles of hard-shelled fruits (Strychnos camptoneura, fruits of another unidentified Strychnos species, Saba comorensis and Calancoba glauca), which based on fragments, marks and bruises appeared to have been smashed open against roots, rocks and vines (online suppl. Material 20; Appendices: Fig. 17a-c). Eight out of 28 of the fruit-smashing sites (29\%) were associated with chimpanzee evidence such as tooth marks on the fruit or other feeding remains. We found no evidence of such behaviour to the south of the Uele River, including at Rubi-Tele, despite local availability of Strychnos fruits.

\section{African Giant Snail-Pounding}

Main Survey Regions

We found a large number of African giant snails (Arachatina marginata) that had been pounded open against the bases of trees. We have yet to confirm via direct 
observation that chimpanzees pound open these snails. Because marsh mongooses (Atilax paludinosus) also pound snails against trees [Hicks, 2010], we must be cautious in our interpretation. Nevertheless, during the 2004-2009 survey period, 11\% of the snail pound sites were within $10 \mathrm{~m}$ of chimpanzee evidence, and $21 \%$ were within $50 \mathrm{~m}$ [Hicks, 2010]. At Leguga, we found a pounded snail a few centimetres from a ground nest, and at a nearby site we found pounded snails in association with smashed termite mounds, nest sites and chimpanzee feeding remains (Appendices: Fig A18a, b). Both of these Leguga sites were located far away from streams in which mongooses are commonly found. On one occasion, chimpanzee vocalizations led project researcher $\mathrm{H}$. Silegowa to a site where he found a freshly pounded giant snail (Appendices: Fig. A18c; online suppl. Material 21). At some pounding sites, fragments of snail shell were found projecting from the strike marks on a nearby tree (Appendices: Fig. A18d).

\section{Rubi-Tele}

The PanAf team observed pounded snails at Rubi-Tele as well. In August 2015, A.E.A. and team found a pile of freshly pounded snails, some still uneaten, approximately $120 \mathrm{~m}$ from where he had just heard chimpanzee vocalizations and $40 \mathrm{~m}$ from fresh remains of Afromomum fruits eaten by the apes. At another site, researchers found a pile of about 10 freshly pounded snail shells within $4 \mathrm{~m}$ of a tree containing a fresh chimpanzee nest still smelling of urine. As was the case at other regions, chimpanzees are not the only potential snail-pounders at Rubi-Tele: on one occasion, A.E.A. observed a mongoose smashing open snails.

\section{Tortoise-Pounding}

At two localities in the Bili-Uéré landscape, one to the north and one to the south of the Uele River, T.H. encountered tortoises which had probably been pounded open by chimpanzees (north: Kinixys belliana; south: Kinixys erosa). In one case the tortoise had been smashed open against a rock, and in the other case against a buttress. In both cases T.H. found the smashed tortoises in association with recent chimpanzee evidence and in areas where chimpanzees had been recently sighted [Hicks, 2010; Hicks et al., in press].

\section{Discussion}

Beginning at least 3.5 million years ago, the material technology of our human ancestors progressed from the use of digging sticks [d'Errico et al., 2001] to simple flaked stone tools [Harmand et al., 2015] and eventually to Acheulean hand axes [Lepre et al., 2011] and the taming of fire [Wrangham, 2009]. Each of these technologies likely served as a key step in the development of what would lead to the explosion of human cumulative culture. The technological adaptations used by the earliest bipedal apes for foraging and hunting were likely relatively simple, and, with the exception of stone tools, perishable and unlikely to leave a trace in the fossil record [Panger et al., 2002]. For this reason, we must rely on the non-human great apes to understand the range of technological behaviours that was likely present in our extinct ancestors [Rolian and Carvalho, 2017]. Chimpanzees (P. troglodytes), with their diverse set of lithic and plant tools and their occupation of a wide range of habitats in Central and 
West Africa, serve as an excellent model for reconstructing the likely technological capacity of hominins [McGrew, 1992]. Until now, researchers have ignored the largest intact population of the species, which inhabits the vast unexplored forests and savannas of the DRC [Hicks et al., 2014].

We have documented a new ensemble of chimpanzee behaviours, which may represent one of the major proposed "cultural realms" for the species. The chimpanzees of the Bili-Uéré region of northern DRC are united by a tradition that includes: (a) the use of a variable tool kit for extractive foraging for insects, such as ant-dipping tools for Dorylus and ponerine ants, probes and sticks to obtain honey from stingless bee nests, (b) the use of percussive technology for pounding open termite mounds, snails and tortoises, (c) frequent ground-nesting and (d) ignoring the readily available Macrotermes termites, which are consumed by other populations of the same species. Within this overarching similarity, however, there are some important potential regional differences: no sign of honey predation was found to the south of the Uele River, including at Rubi-Tele (although the short duration of the study precludes us from concluding that the South Uele chimpanzees do not use tools to acquire honey). North of the Uele, the chimpanzees use extremely long sticks to probe for epigaeic Dorylus ants, while such behaviour is unknown for the south. Although chimpanzees ate both kinds of ants in both regions, the apes appeared to exploit more ponerine ants in the south and Dorylus in the north, despite a similar availability of these ants (Table 7). To the south we found only one epigaeic Dorylus tool site, compared to many for ponerine ants. We did find, however, epigaeic Dorylus ants in dung samples in the South Uele survey region of Rubi-Tele, and intermediate ants D. kohli in dung in the South Uele region of Akuma.

The North Uele chimpanzees used the following tool types: a long driver ant probe, a ponerine ant probe, a $D$. kohli wand, a honey-digging stick and a honey tree probe. Epigaeic Dorylus tools were longer than other tool types and D. kohli tools were thinner. In concordance with their presumed method of use, honey-digging sticks predicted blunted and brushed tool ends. All tools found in association with bees, honey and/or wax were also associated with evidence for digging, whereas few of the other tools were.

In both Hicks [2010] and Sanz et al. [2010], the authors made the incorrect assumption that, in northern DRC, all stick tools found in association with non-driver ant insect holes had been used for harvesting ponerine ants. Although Hicks separated out the epigaeic driver ant tools for analysis, Sanz et al. did not, meaning that the tool dimensions presented in the latter paper as "ant dips" were actually a combination of Dorylus, ponerine ant and honey-digging tools.

South of the Uele River, we found only short probes for ponerine ants and (on only one occasion) epigaeic Dorylus. The longest tool in this region measured 88.6 $\mathrm{cm}$, and the average length was less than half that. We found no digging signs or traces of honey or wax at any of the southern tool sites. This may be an effect of limited survey effort, but the fact that the PanAf team independently found tools at Rubi-Tele with the same characteristics as other South Uele survey regions makes it likely to reflect a real difference.

Unexpectedly, we encountered no unambiguous stick tools of any kind over the $286 \mathrm{~km}$ surveyed at survey regions west of Buta (Fig. 7), despite the discovery of D. kohli ants in an Akuma dung sample and claims by locals that they had observed tool-assisted ant-dipping behaviour there. It is unlikely that adult ants could end up 
in chimpanzee faeces without tools having been involved [C. Boesch, pers. observation], although this can occur with ant larvae [Boesch and Boesch, 1990].

Sanz et al. [2010] describe a tool set used by the chimpanzees of Goaulougo, Republic of Congo, to prey upon the epigaeic driver ant $D$. wilverthi. One of the components of this set was called a "perforator," a long tool that was inserted into the ant nest to stir up ants; following this, the chimpanzees switched to smaller tools to dip for the now agitated ants. The Goualougo perforator sticks were significantly longer and thicker than the ant-dipping tools. It is unlikely that the long North Uele epigaeic Dorylus tools were used in the same way, as the distribution of the tool lengths did not differ significantly from unimodal and, unlike in the case of the Goualougo short dipping tools, Bili-Uéré chimpanzees only rarely used herbaceous tools. In addition, at $26 \%$ of the 23 North Uele epigaeic Dorylus tool sites, only one tool was present. Unlike the Goualougo perforators, which in $78 \%$ of cases had the leafy ends still attached, the driver ant dip tools used by the North Uele apes had in $94 \%$ of cases been stripped of their leafy ends.

Possible effects of habitat type on tool characteristics may exist: the only tool type we commonly found in savanna-associated habitats was the epigaeic Dorylus long probe ( $20 \%$ of sites) (we also found 1 of the 2 honey tree probe sites in this habitat). Given that savanna is a common habitat type north of the Uele River and is absent to the south, we cannot rule out that this difference may contribute to the rarity of epigaeic Dorylus probing and the lack of long probes used to prey on them in the south. The fact, however, that epigaeic Dorylus are preyed upon with tools at other heavily forested chimpanzee study sites such as Ngotto and Goualougo [Hicks et al., 2005; Sanz and Morgan, 2007] makes this explanation unlikely. Other possible effects of habitat may exist: ponerine ant site tools were the only tool type we found in herb patches, and were also, together with honey ground tools, the only type we found in Gilbertiodendron mono-dominant forest.

\section{Tool Use Techniques}

Clear signs of excavation confirmed that the chimpanzees used stick probes to dig honeycomb out of underground beehives. During filming of chimpanzees in the Gangu South Forest using D. kohli probes, they could be seen gently dipping, not thrusting, the wands into the ant holes. The ants crawled up the tools and the apes then transferred them into their mouths. We could see an adult male in the foreground using a one-handed mouth-off technique, such as has been observed for chimpanzees preying on intermediate driver ants at Bossou, Taï and other sites [Humle and Matsuzawa, 2002]. Likewise, we camera-trapped 2 chimpanzee females using a similar one-handed dip approach to harvest unidentified insects off the ground, occasionally lightly brushing them off their feet. Given the relative ease with which the chimpanzees walked through these insects, they were almost certainly not epigaeic Dorylus ants, and the dipping technique used did not match the digging and probing methods used for honey and epigaeic Dorylus/ponerine ants, respectively. As there is no evidence that these chimpanzees use tools to acquire surface-swarming M. muelleri, the most likely candidates are thus intermediate Dorylus ants.

It is unknown how exactly the chimpanzees used probes to harvest ponerine ants or arboreal meliponine bees, except that for the most part digging was not involved. As for the ponerine ant tools, we often found them projecting straight up out of single 
small, unexcavated holes in ant nests. We had the impression that the chimpanzees were using the sticks to disable the stinging ponerines by crushing them inside their nests. Ponerines, unlike epigaeic Dorylus ants, are unlikely to bite onto an intruding stick and usually retreated into their nests when we disturbed them. Given the painful nature of their stings, it is understandable that the chimpanzees would seek to disable these ants before eating them.

The use of extremely long probes to harvest epigaeic Dorylus to the north (but not the south) of the Uele is consistent with the hand-swipe technique [McGrew, 1974] used by chimpanzees at a number of sites across Africa. First a long tool is thrust into a nest or surface swarm. When the ants flood up the tool, the chimpanzees use one hand to sweep the insects off and into their mouths, while holding the tool with another hand or foot. The use of this technique in itself would not explain why the North Uele tools are so much longer than those used by other chimpanzee populations across Africa. We found a significant difference in the depths of epigaeic Dorylus holes compared to the other insect holes we measured, which could potentially explain the exceptional length of these tools. This still, however, does not explain why other populations of epigaeic Dorylus-tool-using chimpanzees in similar environments do not also make such long tools. A comparative study of soil density, ant behaviour and hole depth, along with other possible ecological differences between the sites [see Möbius et al., 2008], should be carried out before we can assume a purely cultural explanation.

\section{Percussive Technology}

The chimpanzees of northern DRC have extended their percussive technology beyond the typical fruits to target termite mounds and possibly other food sources with their pounding behaviour. We found termite mound-pounding sites for both Cubitermes and T. macrothorax across most of the approximately $50,000-\mathrm{km}^{2}$ survey area, representing a widespread chimpanzee behavioural pattern shared across different habitats. The prevalence of this behaviour during the early wet season at Bili is similar to that seen in the northern community of Taï Forest, Ivory Coast. There the chimpanzees only pound open Thoracotermes mounds coinciding with the onset of the first rains of the wet season, around April [Luncz and Boesch, 2015; L. Luncz, pers. commun.]. During our 3-week-long visit to the Gangu Forest during the dry season, we found only 1 pounded termite mound, compared to 5 freshly pounded mounds encountered over a similar period of time spent there during the wet season. The absence of pounded mounds at the Zapay site, which we visited in the dry season, may be explained by this seasonal pattern. It is during the wet season that the aerial parts of the mound are inhabited by termites.

Researchers have documented the pounding of fruits by chimpanzees against tree trunks, limbs and buttresses without the use of a hammer at a number of longterm research sites (Gombe [Goodall, 1986]; Assirik [McGrew et al., 1988; Hunt and McGrew, 2002]; Mahale [Nishida and Uehara, 1983]; Taï [Boesch and Boesch-Achermann, 2000]. In our study, evidence of Strychnos fruit-pounding was limited to North Uele survey regions, despite the presence of appropriate fruit species to the south. Other than the single possible case of a Desplatsia fruit used to hammer open a termite mound, we found no signs of hammer use on our surveys, which is consistent with the notion that this behaviour is limited to West Africa [Boesch and Boesch-Achermann, 2000]. 
The circumstantial evidence linking chimpanzees to pounding sites of African giant snails is strong but not conclusive. Hicks [2010] argued that most of the numerous snail smash sites found at a distance from rivers and streams were probably made by chimpanzees. Given that marsh mongooses are known to be responsible for some of the sites, however, we must be cautious in our interpretation of this evidence until camera trap footage or other more direct evidence becomes available.

The evidence for tortoise-pounding by the chimpanzees is provocative, given that J.H. found evidence of tortoise predation approximately $400 \mathrm{~km}$ south-east of Bili-Uéré at Epulu, but must remain tentative until further, more direct evidence is found. If confirmed, it would add to the unusual vertebrate prey repertoire of the Bili-Uéré chimpanzees, including a leopard (Panthera pardus) and a tree pangolin (Phataginus tricuspis) [Hicks, 2010; Hicks et al., in press].

\section{Rubi-Tele}

The independent PanAf research team at Rubi-Tele, using comparable methodology, found a set of behaviours similar to that of T.H.'s South Uele survey regions. The evidence gathered by the Rubi-Tele team confirmed the use of tools to probe for ponerine ants, termite mound-pounding (and possibly snail-pounding), as well as a seeming absence of Macrotermes-fishing. Similar to other South Uele survey regions but not to North Uele was a puzzling lack of honey tools, as well as a lack of long probes - or indeed of any tools - to prey on epigaeic Dorylus, although the Rubi-Tele team found both intermediate and epigaeic Dorylus ants in dung samples. This further supports our conclusion that specialized "long driver ant tools" are found only to the north of the Uele River. Rubi-Tele not only extends the range of the northern DRC behavioural complex further to the south-east, but also strengthens our confidence in our findings, given that two separate teams obtained nearly identical results.

\section{Lack of Macrotermes Consumption in Spite of Resource Availability}

Our dung wash evidence, gathered across both the wet and dry seasons, makes it unlikely that the Bili-Uéré chimpanzees consumed Macrotermes. Although the three research teams (Hicks', Dierks' and PanAf Rubi-Tele) found abundant evidence of ants in the dung samples, none of them ever found termites. At research sites where Macrotermes are fished for by chimpanzees, researchers commonly find them in dung (e.g., Gombe, Tanzania [van-Lawick-Goodall, 1968]; Dja, Cameroon [Deblauwe, 2009]; Fongoli, Senegal [Bogart and Pruetz, 2011]). The fact that we also failed to find signs of Cubitermes or T. macrothorax in the dung is likely due to the tiny size of these termite species compared to Macrotermes soldiers with their relatively massive heads and mandibles.

Is it possible that the chimpanzees of northern DRC were using termite tools or consuming Macrotermes by hand and we missed them? Flimsy grass tools such as those used to prey on Macrotermes at Gombe [Goodall, 1986] and at some other sites might be missed; nevertheless, at Gombe, Goodall observed chimpanzees fishing for termites and found tools in the first year of her study prior to habituation. About half of Gombe termite probes were made of grass, but the rest were made of more durable material such as twigs, vines and bark [McGrew et al., 1979]. Researchers have found abundant stick tools used to fish for termites at other study sites with non-habituated chimpanzees as well, for instance in Okorobikó, Equato- 
rial Guinea [Sabater-Pi, 1984], and Ndoki, Congo [Kuroda et al., 1996]. At Mount Assirik, researchers frequently found tools at termite mounds, mostly made of twigs, vines and more perishable leaf stalks, and very rarely grass [McGrew et al., 1979]. In 2002, at Fongoli, Senegal, prior to habituation, researchers found $24 \mathrm{Mac}$ rotermes probes made of woody materials and 34 made of grass [Pruetz and Bertolani, 2007]. Lack of palatability of the local Macrotermes is unlikely to explain their absence from the diets of North Uele chimpanzees, as our Zande assistants at Bili frequently scooped up Macrotermes from surface swarms and consumed them raw with relish.

We must be cautious in assuming that lack of tool use in an area means that insects are not consumed there. According to L. Luncz [pers. commun.], chimpanzees in the Taï Forest eat termites of the genera Macrotermes and Cubitermes when the alates fly out, but do not pound open their mounds or use tools. Alates, unlike soldiers, would likely be missed in dung. The complete absence of any tool-like objects near the abundant Macrotermes mounds we encountered in our surveys, as well as the lack of termite remains in dung washes at multiple northern DRC survey sites conducted by multiple research teams makes it extremely unlikely that we would have missed anything other than opportunistic consumption of Macrotermes alates, with or without tools (more caution must be taken with Cubitermes and Thoracotermes; although we found no signs of these insects in any of the dung samples, their tiny size and their lack of large and easily preserved Macrotermes-style mandibles make it unlikely that these termites would show up in the dung). We found other large unidentified termite mounds on the North Uele savannas, but we never found any signs of visits by chimpanzees, and indeed evidence of chimpanzees visiting the savanna was negligible.

\section{Modern Primates as Subjects of Archaeology}

In our study, we followed the lead of palaeoanthropologists in reconstructing primate behaviour based mostly on artefacts left behind, with the advantage that our sites were minutes, days or at most weeks old, not millions of years. There is a precedent for this in primatology as well. Struhsaker and Hunkeler [1971] first documented nut-cracking in the Taï Forest chimpanzees using indirect evidence; the behaviour was later confirmed with direct observations by Boesch and Boesch [1990]. Several ground-breaking studies have recently blurred the line between palaeoanthropology and primatology. Both Boesch and Boesch-Achermann [2000] and van Schaik and Knott [2001] reached conclusions about the presence or absence of certain great ape material traditions based on indirect data gathered during surveys of unhabituated populations of western chimpanzees (P. t. verus) and Sumatran orang-utans (Pongo abelii), respectively. At Taï Forest, researchers using archaeological methods documented the persistence of a chimpanzee nut-hammering tradition dating back several thousands of years [Mercader et al., 2002] and documented a distance-decay effect in the distribution of stone artefacts at Taï [Luncz et al., 2016]. Sept [1992] compared eastern DRC chimpanzee nest sites to hominin home bases, while Luncz et al. [2015] used the artefacts left behind by an unhabituated Taï community to infer the natal nut-hammering habits of female chimpanzees who had transferred into a habituated community. Certainly there are limits to inferences that can be drawn from indirect evidence, and we must exercise caution in doing so: as an example, during many years of behavioural observations and dung analysis at the Taï Forest study site, 
the researchers found no evidence of monkey hunting. Only full habituation revealed that this population hunted monkeys at a greater frequency than any other studied to date [Boesch, pers. observation; Boesch and Boesch-Achermann, 2000]. We hope to return to DRC and achieve more direct observations of tool use behaviours in the Bili chimpanzees.

\section{Comparison of Insect Availability and Tool Use with Other Long-Term \\ Chimpanzee Study Sites}

We have compiled insect availability data for key species consumed in this study at other chimpanzee research sites across Africa (Table 10). Because transect strip widths differed between surveys, and some studies (particularly in the case of Macrotermes) recorded only occupied insect mounds whereas others recorded both occupied and abandoned mounds, we are limited in the conclusions we can draw from these comparisons. Also problematic is that a number of studies reported their insect densities as per hectare or per square kilometre rather than encounter rate per kilometre. Nevertheless, we can still draw several important conclusions.

\section{Macrotermes Termites}

The insect survey transects at La Belgique, Cameroon, where chimpanzees use tools to fish for Macrotermes, had a 10-m strip width identical to that of our study [Deblauwe, 2009; Deblauwe, unpubl. data]. The encounter rates of Macrotermes mounds there were almost identical to those at North Uele, where Macrotermes are ignored. The Bili numbers may be inflated, as in our counts we did not distinguish living, occupied termite mounds from abandoned ones. The contrasting cases of Fongoli (chimpanzees eat termites, high termite encounter rates) [Bogart and Pruetz, 2011], and Budongo [Hedges and McGrew, 2012] and Seringbara [Koops et al., 2013] (chimpanzees do not eat termites, low termite encounter rates) indicate that, per Koops et al. [2013, 2014], the availability of Macrotermes probably has some impact on the likelihood of exploitation. Nevertheless, Macrotermes mound encounter rates were extremely low at Gombe [McGrew et al., 2007], where termite-fishing regularly occurs (but strip widths were narrow, and it is unclear whether only active mounds were counted). Considering all of these data together, it is unlikely that a lack or scarcity of Macrotermes mounds per se explains the absence of termite-fishing at North Uele. South Uele, on the other hand, had much lower Macrotermes encounter rates.

\section{Termites of the Genera Cubitermes and Thoracotermes}

Encounter rates in northern DRC for mounds of both of these termite species were high compared to those recorded at other sites such as Gombe (for Cubitermes) [O'Malley, 2011; O'Malley, pers. commun.] and Taï (for Thoracotermes) [Luncz and Boesch, 2015; Luncz, unpubl. data]. At other sites such as Taï, the strip widths were wider $(10 \mathrm{~m})$ than ours; thus, the encounter rates are not directly comparable and were probably elevated at Taï, Gombe, etc. compared to Bili. At La Belgique, encounter rates for both termite species seemed more comparable to those of northern DRC, but again, strip widths there were wider [Deblauwe, 2009; Deblauwe, unpubl. data]. Thus, it may well be that Cubitermes and Thoracotermes are more available at northern DRC than at other sites. Future projects should standardize these counts to see whether Cubitermes and Thoracotermes are really more common in northern DRC than elsewhere. 
Table 10. Comparison of availability of insect types at chimpanzee research sites

\begin{tabular}{|c|c|c|c|c|c|c|c|c|c|}
\hline Site & Strip width, m & $\begin{array}{l}\text { Macrotermes } \\
\text { mounds } \\
(n / \mathrm{km}= \\
\text { rate })\end{array}$ & $\begin{array}{l}\text { Cubitermes } \\
\text { mounds } \\
(\mathrm{n} / \mathrm{km}= \\
\text { rate })\end{array}$ & $\begin{array}{l}\text { Thoraco- } \\
\text { termes } \\
\text { mounds } \\
(n / \mathrm{km}= \\
\text { rate) }\end{array}$ & $\begin{array}{l}\text { Epigaeic } \\
\text { Dorylus } \\
\text { nests } \\
(n / \mathrm{km}= \\
\text { rate) }\end{array}$ & $\begin{array}{l}\text { Epigaeic } \\
\text { Dorylus } \\
\text { trails and } \\
\text { swarms } \\
(n / \mathrm{km}= \\
\text { rate })\end{array}$ & $\begin{array}{l}\text { Ponerine } \\
\text { colonies, } \\
\text { trails and } \\
\text { swarms } \\
(n / \mathrm{km}= \\
\text { rate })\end{array}$ & $\begin{array}{l}\text { Megaponera } \\
\text { analis } \\
\text { only, colonies, } \\
\text { trails and } \\
\text { swarms } \\
(n / \mathrm{km}= \\
\text { rate })\end{array}$ & Source \\
\hline North Uele & $\begin{array}{l}\text { Macro }=10 \\
\text { Thorac }+ \text { Cub }=2 \\
\text { Epig. Dorylus } \\
\text { Swarms }=2 \\
\text { Nests }=4 \\
\text { Ponerines }=2\end{array}$ & $\begin{array}{l}120 / 128.6 \\
0.9 \text { AM }\end{array}$ & $\begin{array}{l}58 / 2 \\
29 \text { AM }\end{array}$ & $\begin{array}{l}11 / 2 \\
5.5 \mathrm{AM}\end{array}$ & $\begin{array}{l}4 / 174 \\
0.02 \mathrm{OM}\end{array}$ & $\begin{array}{l}16 / 174.7 \\
0.09\end{array}$ & $\begin{array}{l}69 / 86.8 \\
0.80\end{array}$ & - & 1 \\
\hline South Uele & $\begin{array}{l}\text { Macro }=10 \\
\text { Thorac }+ \text { Cub }=2 \\
\text { Epig. Dorylus } \\
\text { Swarms = } 2 \\
\text { Nests }=4 \\
\text { Ponerines }=2\end{array}$ & $\begin{array}{l}55 / 394.8 \\
0.14 \text { AM }\end{array}$ & $\mathrm{P}$ & $\mathrm{P}$ & $\begin{array}{l}\text { All: } 38 / 399.8 \\
0.10 \\
\text { OM: } 6 / 399.8 \\
0.02\end{array}$ & $\begin{array}{l}26 / 399.8 \\
0.07\end{array}$ & $\begin{array}{l}37 / 394.8 \\
0.09 \mathrm{MO}\end{array}$ & - & 2 \\
\hline $\begin{array}{l}\mathrm{La} \\
\text { Belgique, } \\
\text { Nov 04 } \\
(9.83 \mathrm{~km})\end{array}$ & 10 & $\begin{array}{l}9 / 9.8 \\
0.92 \mathrm{OM}\end{array}$ & $\begin{array}{l}\text { OM: } \\
52 / 2.6 \\
20 \\
\text { Total: } \\
53 / 2.6 \\
20.4\end{array}$ & $\begin{array}{l}\text { OM: } \\
24 / 8.63 \\
2.78 \\
\text { Total: } \\
64 / 8.63 \\
7.42\end{array}$ & $\begin{array}{l}0 \\
\mathrm{P}^{1}\end{array}$ & - & - & - & 3 \\
\hline $\begin{array}{l}\text { La } \\
\text { Belgique, } \\
\text { Feb 05 } \\
(9.83 \mathrm{~km})\end{array}$ & 10 & $\begin{array}{l}8 / 9.8 \\
0.82 \mathrm{OM}\end{array}$ & $\begin{array}{l}\text { OM: } \\
49 / 2.6 \\
18.85 \\
\text { Total: } 57 / 2.6 \\
\\
21.92\end{array}$ & $\begin{array}{l}\text { OM: } \\
27 / 8.63 \\
3.13 \\
\text { Total: } \\
81 / 8.63 \\
9.39\end{array}$ & $\begin{array}{l}0 \\
\mathrm{P}^{1}\end{array}$ & - & - & - & 3 \\
\hline $\begin{array}{l}\text { Gashaka- } \\
\text { Kwano }\end{array}$ & 10 & - & $\mathrm{P}^{2}$ & - & $\begin{array}{l}3 / 106.2 \\
0.03 \mathrm{OM}\end{array}$ & $\begin{array}{l}43 / 106.2 \\
0.43\end{array}$ & $\mathrm{P}^{2}$ & $\mathrm{P}^{2}$ & 4 \\
\hline Budongo & 6 & $\begin{array}{l}0 / 6 \\
0 \\
\mathrm{P}^{3}\end{array}$ & $\begin{array}{l}124 / 6 \\
20.7\end{array}$ & - & 0 & $\begin{array}{l}1 / 6 \\
0.20\end{array}$ & - & - & 5 \\
\hline Taï North & 10 & - & - & $\begin{array}{l}43 / 18 \\
2.39\end{array}$ & - & - & - & - & 6 \\
\hline Taï South & 10 & - & - & $\begin{array}{l}94 / 22 \\
4.27\end{array}$ & - & - & - & - & 7 \\
\hline Taï East & 10 & - & - & $\begin{array}{l}91 / 25.5 \\
3.57\end{array}$ & - & - & - & - & 8 \\
\hline Gombe & 6 & $\begin{array}{l}9 / 12 \\
0.75 \mathrm{OM}\end{array}$ & $\begin{array}{l}64 / 12 \\
5.33\end{array}$ & - & $\begin{array}{l}2 / 12 \\
0.17\end{array}$ & $\begin{array}{l}3 / 12 \\
0.25\end{array}$ & $\begin{array}{l}36 / 12 \\
3 \mathrm{Co} \\
40 / 12 \\
3.33 \mathrm{Tr} \\
76 / 12 \\
6.33 \text { total }\end{array}$ & $\begin{array}{l}4 / 12 \\
0.33 \mathrm{Co} \\
5 / 12 \\
0.42 \mathrm{Tr} \\
9 / 12 \\
0.75 \text { total }\end{array}$ & 9 \\
\hline Gombe & 6 & $\begin{array}{l}1 / 2.37 \\
0.42 \text { OM? }\end{array}$ & - & - & - & - & - & - & 10 \\
\hline Mahale $^{4}$ & 6 & $\begin{array}{l}0 / 10 \\
0 \text { OM? }\end{array}$ & - & - & - & - & - & - & 11 \\
\hline Fongoli & 8 & $\begin{array}{l}121 / 6.4 \\
18.9 \mathrm{OM}\end{array}$ & - & - & - & - & - & - & 12 \\
\hline Kalinzu & 10 & $0 / 54$ & - & - & & $\begin{array}{l}27 / 54 \\
0.50\end{array}$ & - & - & 13 \\
\hline
\end{tabular}


Table 10 (continued)

\begin{tabular}{|c|c|c|c|c|c|c|c|c|c|}
\hline Site & Strip width, $\mathrm{m}$ & $\begin{array}{l}\text { Macrotermes } \\
\text { mounds } \\
(n / \mathrm{km}= \\
\text { rate })\end{array}$ & $\begin{array}{l}\text { Cubitermes } \\
\text { mounds } \\
(n / \mathrm{km}= \\
\text { rate })\end{array}$ & $\begin{array}{l}\text { Thoraco- } \\
\text { termes } \\
\text { mounds } \\
(n / \mathrm{km}= \\
\text { rate })\end{array}$ & $\begin{array}{l}\text { Epigaeic } \\
\text { Dorylus } \\
\text { nests } \\
(n / \mathrm{km}= \\
\text { rate })\end{array}$ & $\begin{array}{l}\text { Epigaeic } \\
\text { Dorylus } \\
\text { trails and } \\
\text { swarms } \\
(n / \mathrm{km}= \\
\text { rate })\end{array}$ & $\begin{array}{l}\text { Ponerine } \\
\text { colonies, } \\
\text { trails and } \\
\text { swarms } \\
(n / \mathrm{km}= \\
\text { rate })\end{array}$ & $\begin{array}{l}\text { Megaponera } \\
\text { analis } \\
\text { only, colonies, } \\
\text { trails and } \\
\text { swarms } \\
(n / \mathrm{km}= \\
\text { rate) }\end{array}$ & Source \\
\hline Seringbara & 4 & $\begin{array}{l}1 / 26.2 \\
0.04 \mathrm{OM}\end{array}$ & $\begin{array}{l}\text { (March) } \\
173 / 26.2 \\
6.6 \\
(\text { Oct) } 244 / 26.2 \\
9.3\end{array}$ & - & - & $\begin{array}{l}2 / 26.2 \\
0.08^{5}\end{array}$ & - & - & 14 \\
\hline
\end{tabular}

-, no data available; grey sections, the insects are consumed regularly by chimpanzees at this site; AM, all mounds; OM, occupied mounds only; OM?, not clear if limited only to occupied mounds; MO, mounds only; Co, colonies; Tr, trails; P, present at the site. Sources: 1, 2, this study; 3, Deblauwe [2009] and Deblauwe [unpubl. data] (recalculated by Hicks); 4, Fowler and Sommer [2007] and Schöning et al. [2007, pers. commun.]; 5, Hedges and McGrew [2012]; 6, Luncz and Boesch [2015] and Luncz [unpubl. data] (recalculated by Hicks); 7, 8, Luncz and Boesch [2015]; 9, O'Malley [2011] and O'Malley [pers. commun.]; 10, McGrew et al. [2007] (referring to work described in van Lawick-Goodall [1968]); 11, McGrew et al. [2007] (referring to work described in McGrew and Collins [1985]); 12, Bogart and Pruetz [2011]; 13, Koops et al. [2015] and Koops [pers. commun.]; 14, Koops et al. [2013].

${ }^{1}$ Deblauwe, 2009: "I encountered visible nests of Dorylus sjöstedti and D. wilverthi occasionally, but never in belt-transects or along line-transects, and hence they are probably less available than nests of Oecophylla, Crematogaster, and Tetramorium."

${ }^{2}$ Alejandra Pascual-Garrido, personal communication, Megaponera analis are common at Gashaka. March 8, 2016. Researchers found remains of this species in a very small proportion of chimpanzee dung samples ( 2 out of 3 found were pupae) (Schöning et al., 2008). Their consumption is thus extremely rare.

${ }^{3}$ At Budongo, Macrotermes swarms were absent from transects as well as mounds, although these termites are present at the site.

${ }^{4}$ The situation at Mahale is complicated, in that one community of chimpanzees (B group) fishes regularly for Macrotermes, whereas the neighbouring K group does not. Collins and McGrew [1987] found that this was explained by a near absence of Macrotermes in K group's range. Termite density data from that paper, however, was not comparable to ours, and we thus used data from the source listed.

${ }^{5}$ Includes a very small proportion of non-epigaeic Dorylus.

\section{Epigaeic Dorylus}

Strip widths for these ants were also much narrower in northern DRC than at other sites, making insect density comparisons difficult. Seringbara's strip width (4 m; Table 10) is the most directly comparable [Koops et al., 2013], and the encounter rates for trails and swarms were quite similar (the ants are preyed on at both sites). More informative is the case of La Belgique [Deblauwe, 2009; Deblauwe, unpubl. data], where researchers encountered no driver ants on the transects. This seems to indicate low availability, yet the ants are present and the chimpanzees prey upon them with tools. At Kalinzu, on the other hand, where epigaeic Dorylus are preyed upon with stick tools, encounter rates were much higher than in northern DRC [Koops et al., 2015; Koops, pers. commun.]. Once again there seems to be no clear link between availability and presence of tool use, although we must be cautious until more systematic comparisons can be made.

\section{Ponerine Ants}

Looking at the Ponerinae as a whole, encounter rates were high at Gombe (where chimpanzees do not prey on these insects) [O'Malley, 2011] compared to northern DRC (granted that the Gombe strip widths were wider). In this case, therefore, it is difficult to argue that in northern DRC the chimpanzees dip for these ants because there are more of them.

\section{Behavioural Continuity across Northern DRC: A Potential Chimpanzee Mega-Culture}

The characteristics of the Bili-Uéré honey-digging sites appear to be almost identical to those documented for P. t. troglodytes at Loango, Gabon [Boesch et al., 2009; 

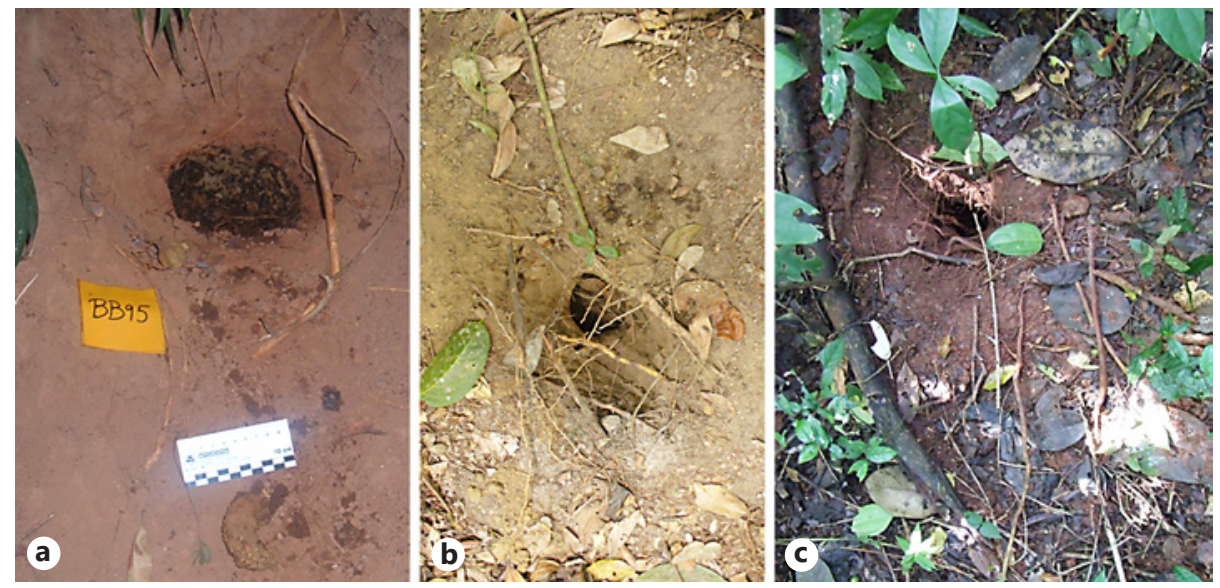

Fig. 12. Honey-digging sites at: Gashaka-Gumti, Nigeria (a) (photograph courtesy of Alejandra Pascual-Garrido), Loango, Gabon (b) (photograph courtesy of Edward Wright), and Gangu North, DRC (c) (the latter found on September 9, 2012).

Estienne et al., 2017a, b], and P. t. ellioti at Gashaka-Gumti [Fowler and Sommer, 2007] and Ngel Nyaki [Dutton and Chapman, 2015] (Fig. 12). Researchers have also found this behaviour in three other populations of Central African P. t. troglodytes (Bai Hokou [Fay and Carroll, 1994]; Dja [Deblauwe, 2006] and Ngotto [Hicks et al., 2005]) and in P. t. schweinfurthii at Kahuzi Biega, DRC [Yamagiwa et al., 1988]. J.H.'s team of experienced Bambuti guides in Epulu, Ituri DRC, reported that chimpanzees there, in addition to breaking open beehives in trees with stick levers, regularly excavate the underground nests of meliponine bees, leaving discarded stick tools beside the holes [J. Hart, pers. commun. with assistants Soumali, Atibo, Baya and Paul]. Given that researchers have found abundant honey-digging sites at Central African sites but these are rare or absent in West Africa or in the far east of chimpanzees' range (with the single exception of Bulindi [McLennan, 2011]), we can tentatively propose honey-digging as a very large behavioural realm of Central African chimpanzees. It is surprising that in our surveys we failed to find any honey-digging tools to the south of the Uele River. Stingless bees are certainly present in these regions, and the chimpanzees' behaviours to the north and south are otherwise quite similar.

In addition, chimpanzees use stick tools to access underground termites at Goaulougo and in nearby forests [Fay and Carroll, 1994; Sanz et al., 2004], as well as at Dja [Deblauwe, 2006], raising the possibility that the use of tools to puncture or excavate underground insect resources (as opposed to the more widespread behaviour of probing/dipping into already existing ant or bee holes) is mostly limited to Central Africa and is nearly ubiquitous there [but see McLennan, 2011]. It remains to be seen whether this (1) was ancestral to the population that colonized the area, (2) represents an independent evolution of the trait at several sites, with perhaps some unknown environmental factor occurring in the Congo Basin which has encouraged this repeated reinvention, or (3) was a single invention that has spread across Central Africa via cultural dispersal. 
In addition to the behaviours described above, the Bili-Uéré chimpanzees frequently make ground nests, some clearly slept in overnight [Hicks, 2010]. Although this behaviour was found to decline or disappear in proximity to human activity, in more undisturbed forests the proportion of ground nests ranged from 14.6\% (Gangu) to $28 \%$ (Leguga) of total nests (2004-2009 surveys). Ground nesting was common on both sides of the Uele River, and throughout this range the chimpanzees employed similar materials and construction styles, often involving a complex interweaving of saplings and Marantaceae herbs. In 2012, a new survey of Camp Louis-Gangu revealed that the behaviour remained common ( 49 out of 726 nests, i.e. $6.8 \%$, on 662 $\mathrm{km}$ of recces and 4 out of 120 nests, i.e. $3.3 \%$, on $26 \mathrm{~km}$ of transects [Hicks, 2014]). Surveys of the nearby North Uele forests Bambillo and Dume also revealed the presence of ground nests. In addition, we found simpler "leaf cushions" (as described by Hirata et al. [1998] for Bossou) at a number of localities to the north and south of the Uele River.

Given the similarity of behaviours across this and the wider region of Northern DRC (ground nesting, leaf cushions, termite mound-pounding, ant- and honey-dipping and a lack of Macrotermes-feeding), Hicks [2010] proposed the existence of a chimpanzee "mega-culture." Since then, we have found subtle differences in the behavioural repertoires to the north and south of the Uele River: no honey-digging or fruit-pounding sites were found south of the Uele, and differences may exist in ant prey species preferences and tool types which are not tied to resource availability. Nevertheless, overall behavioural continuity appears to be characteristic of the region, which is curious given the marked diversity seen in chimpanzee behaviour elsewhere. This is the case despite the marked differences in ecological conditions to the north and south of the Uele River (savanna woodland mosaic vs. continuous moist tropical forest, respectively), which might have led one to predict the development of very different traditions. Genetic explanations, which may play some role in overall chimpanzee behavioural variation [Langergraber et al., 2010], can for this population probably be ruled out given its interconnectedness and the recent origin of all east African chimpanzees [Gagneux et al., 2001]. Hicks [2010] provided possible explanations for this behavioural continuity. The large size and interconnectedness of the population and/or its recent origin may have limited the opportunities for cultural differentiation, even when the apes encountered different ecological conditions.

Hicks [2010] presented tentative evidence that this behavioural realm may be even more widespread and might extend across northern DRC, reaching as far southeast as Maiko. One of J.H.'s experienced Bambuti field assistants reported that the chimpanzees at Epulu break open and eat termite mounds, but more data are needed to confirm this. Termite mound-pounding appears to be, with the exception of the Taï North community [Luncz and Boesch, 2015], unique to northern DRC, despite the wide availability of Cubitermes and Thoracotermes species across Africa (see, however, Newton-Fisher [1999] for an account of Budongo chimpanzees consuming and sharing a Cubitermes speciosus mound without pounding it open).

\section{Bili-Uéré as a Potential Chimpanzee Cultural Realm}

In the majority of study regions in Bili-Uéré both to the north and to the south of the Uele River, we documented the presence of ground-nesting, ant-dipping, termite mound-pounding and giant snail-pounding sites associated with nearby chimpanzee signs. We propose that this behavioural continuity observed across our 
Table 11. Distribution of behaviours across northern DRC (Tables 7-9)

\begin{tabular}{|c|c|c|c|c|c|c|}
\hline Behaviour & $\begin{array}{l}\text { Present/ } \\
\text { absent } \\
\text { North Uele }\end{array}$ & $\begin{array}{l}\text { Present/ } \\
\text { absent } \\
\text { South Uele }\end{array}$ & $\begin{array}{l}\text { Rubi- } \\
\text { Tele }\end{array}$ & $\begin{array}{l}\text { North Uele survey } \\
\text { regions out of } 9 \text {, } \\
n(\%)\end{array}$ & $\begin{array}{l}\text { South Uele } \\
\text { survey regions } \\
\text { out of } 10 \text {, } \\
n(\%)\end{array}$ & $\begin{array}{l}\text { Rubi-Tele } \\
\text { P/A, including } \\
\text { dung evidence }\end{array}$ \\
\hline Ground nesting & $\mathrm{P}$ & $\mathrm{P}$ & $A ?$ & $8(89)$ & $6(60)$ & $A ?$ \\
\hline Leaf cushion & $\mathrm{P}$ & $\mathrm{P}$ & $\mathrm{A}$ ? & $2(22)$ & $6(60)$ & $A ?$ \\
\hline Epigaeic driver ant probes (all) & $\mathrm{P}$ & $\mathrm{P}$ & A? & $6(67)$ & $1(10)$ & $\mathrm{P}$ \\
\hline Epigaeic driver ant long probes & $\mathrm{P}$ & $\mathrm{A}$ & $\mathrm{A}$ & $6(67)$ & 0 & $\mathrm{~A}$ \\
\hline Epigaeic driver ant short probes & $\mathrm{A}$ & $\mathrm{P}$ & $A$ ? & 0 & $1(10)$ & $\mathrm{P}$ \\
\hline Intermediate Dorylus tools & $\mathrm{P}$ & $\mathrm{A}^{1}$ & A? & $3(33)$ & $0^{1}$ & $\mathrm{P}$ \\
\hline Ponerine ant probes & $\mathrm{P}$ & $\mathrm{P}$ & $\mathrm{P}$ & $3(33)$ & $5(50)$ & $\mathrm{P}$ \\
\hline Stingless bee digging sticks & $\mathrm{P}$ & $\mathrm{A}$ & $\mathrm{A}$ & $3(33)$ & 0 & $\mathrm{~A}$ \\
\hline Stingless bee arboreal probes & $\mathrm{P}$ & $\mathrm{A}$ & $\mathrm{A}$ & $2(22)$ & 0 & $\mathrm{~A}$ \\
\hline Termite mound pound & $\mathrm{P}$ & $\mathrm{P}$ & $\mathrm{P}$ & $5(56)$ & $9(90)$ & $\mathrm{P}$ \\
\hline Fruit pound & $\mathrm{P}$ & A & $\mathrm{A}$ ? & $3(33)$ & 0 & A? \\
\hline Snail pound & $\mathrm{P}$ & $\mathrm{P}$ & $\mathrm{P}$ & $9(100)$ & $10(100)$ & $\mathrm{P}$ \\
\hline $\begin{array}{l}\text { Snail pound within } 10 \mathrm{~m} \text { of } \\
\text { chimpanzee sign }\end{array}$ & $\mathrm{P}$ & $\mathrm{P}$ & $\mathrm{P}$ & 4 out of $7(57)$ & $6(60)$ & $\mathrm{P}$ \\
\hline $\begin{array}{l}\text { Snail pound within } 50 \mathrm{~m} \text { of } \\
\text { chimpanzee sign }\end{array}$ & $\mathrm{P}$ & $\mathrm{P}$ & $\mathrm{P}$ & 4 out of 7 (57) & $8(80)$ & $\mathrm{P}$ \\
\hline Tortoise pound & $\mathrm{P}$ & $\mathrm{P}$ & $\mathrm{A}$ ? & $1(11)$ & $1(10)$ & A? \\
\hline Macrotermes-fishing & $\mathrm{A}$ & $\mathrm{A}$ & $\mathrm{A}$ & 0 & 0 & A \\
\hline
\end{tabular}

P, present; A, absent. Sources: leaf cushions, Hicks [2010]; ground nests, Hicks [2010, 2014]. In all cases where ground nests are listed as present, they made up more than $1 \%$ of nests found at those sites. In the case of Rubi-Tele, we placed question marks beside "absent" when it is uncertain whether the research team had these items in their search image, in other words, when they may have missed them. See online supplementary Material 22 for more detailed basic information. Yoko).

${ }^{1}$ If dung evidence is used as well, then D. kohli consumption and probably tool use was present at 1 of the 10 South Uele sites (Akuma-

$50,000-\mathrm{km}^{2}$ survey region, in which subtle differences in chimpanzee technology are embedded within an overarching similarity, be referred to as the "Bili Chimpanzee Behavioural Realm" (previously termed "the Bili Megaculture" in Hicks [2010]). Given that this appears to be one large interconnected (and thus not genetically differentiated) population, and also that the diversity of habitat types makes an overarching ecological explanation for the behaviours unlikely, our findings are consistent with culture. To speculate, it may reflect a relatively recent dispersal of chimpanzee traditions across northern DRC from an ancestral population, a set of behaviours which has been maintained across this large and ecologically diverse area via cultural override [Hicks et al., 2010], even in different habitats. Some minor differentiation appears to have occurred, leading to differences among tool lengths and the exploitation of honey and particular kinds of ants on different sides of the Uele River (Table 11).

Future research should focus on conducting cultural surveys using comparable methodology across Central Africa in order to confirm the geographical extent of the Bili-Uéré Behavioural Realm. Preliminary findings indicate that it may reach as far east as the border between DRC and Uganda [Hicks, 2010]. We would expect to see a gradual diversification of behaviours with increasing geographic distance, but with many basic components of the culture remaining in place. Clearly, at some as yet unknown location on the map, perhaps on either side of a large geographical barrier, we will find a significant change reflecting the profound differences between the chimpanzee cultures of Uganda and Tanzania versus that of northern DRC. This pattern 
may reflect a past dispersal event and may even turn out to correspond with clear genetic differentiation. For the moment, this discussion must remain speculative, given the dearth of information about chimpanzee traditions in southern Central African Republic, Sudan and western DRC. Reliable information on chimpanzee technology in eastern DRC is also quite patchy. A better understanding of the point of origin for these traditions as well as the history and mechanisms of their spread will require more surveys, as well as more precise and comprehensive genetic analyses [i.e., Fünfstück et al., 2015].

\section{Conclusions}

This study represents a unique large-scale multisite survey of a chimpanzee population that is still interconnected and capable of exchanging genes and memes. Although we have documented intriguing regional differences, what is remarkable is the behavioural continuity which spans two different sides of a major river and extends across different habitat types. We argue that it likely represents another chimpanzee "behavioural realm". The Bili-Uéré landscape provides us with an unprecedented opportunity to understand the dispersal of traditions across a large and intact population of chimpanzees. Efforts must be made to safeguard this remarkable but neglected population with its unique technological complex into the future.

\section{Acknowledgements}

We thank the Ministère de l'Environnement of the DRC and the Institut Congolais pour la Conservation de la Nature (ICCN) for granting us permission to work in the DRC. Laura Darby-Singh and Adam Darby-Singh assisted with the South Uele surveys. Karsten Dierks ran the Pan African Bili-Gangu site and collected data on tools. We thank the following supporters of our project: The Wasmoeth Wildlife Foundation, Lucie Burgers Foundation, International Primate Protection League, African Wildlife Foundation, Le Centre de Rehabilitation des Primates de Lwiro, US Fish and Wildlife Service, Panafrican Programme of the Max Planck Institute for Evolutionary Anthropology, Karl Ammann, Jan Sevink and Jan van Hooff. We also thank Terese Hart, Mimi Arandjelovic, Mizuki Murai, Claudia Nebel, Andreas Walther and Rainer Benz. We are grateful to the hard work and knowledge of our field assistants, in particular Team Leaders Ephrem Mpaka, Henri Silegowa, Gilbert Pakulu, Bebe Bofenda, Ligada Faustin, Chief Mbolibie Cyprian and Kisangola Polycarpe, as well as Olivier Esokeli, Seba Koya, Dido Makeima, Makassi Constant, Likambo, Likongo, Garavura Roger and Kongonyesi. Yisa Ginath and Louwtjie Dutoit provided assistance with the maps, and Sonia Uribe helped to make the figures. Volker Sommer, Alejandra Pascual-Garrido, Anna Nekaris, Vittoria Estienne, Lydia Luncz, Jan van Hoff, Carel van Schaik and 2 anonymous reviewers also provided useful suggestions and feedback.

\section{Author Contributions}

T.H. conceived the research, led the Bili-Uéré survey missions and wrote the manuscript. P.R., P.D. and R.M. also contributed to writing the manuscript.

Statistical analyses, maps and figures: R.M., T.H. and P.R.

Research protocol design: T.H., H.K., J.H., C.B., R.M. and S.M.

The Bili-Uéré Chimpanzee Behavioural Realm

Folia Primatol 2019;90:3-64 
Comments on the manuscript: H.K., J.H., C.B., J.S., A.A., R.M., P.R., P.D. and S.M.

Data collection and survey leadership at Bili: T.H., J.S.

Data collection and survey leadership at Rubi Tele: P.D., R.F., D.Z., M.K. and A.A.

Additional data referring to this article can be found at the following links:

https://figshare.com/articles/Hicks_et_al_2019_Additional_Data_docx_Additional_ Data_relating_to_Hicks_et_al_2019_Bili-Uéré_A_chimpanzee_behavioral_realm_in_DR_ Congo_/7441277

and

https://figshare.com/articles/Hicks_et_al_2019_Notes_Photos_Tool_Sites/7550987.

\section{Appendices}

Fig. A1. a Epigaeic driver ant nest (Dorylus wilverthi, sample identified by C. Schöning) on a hill above the Ngulumbi Stream, Camp Louis region, August 2006. Note the deep cavernous holes at the base of a large tree and the enormous red mound surrounding the tree base. Projecting from the mound are the long sticks used by chimpanzees to probe for the ants. $\mathbf{b}$ Non-epigaeic driver ants $(D$. kohli) targeted by chimpanzees in June 2005, at Gangu South. Note the lack of a mound and the wide shallow depressions in the soil. The site was not located at the base of a large tree.

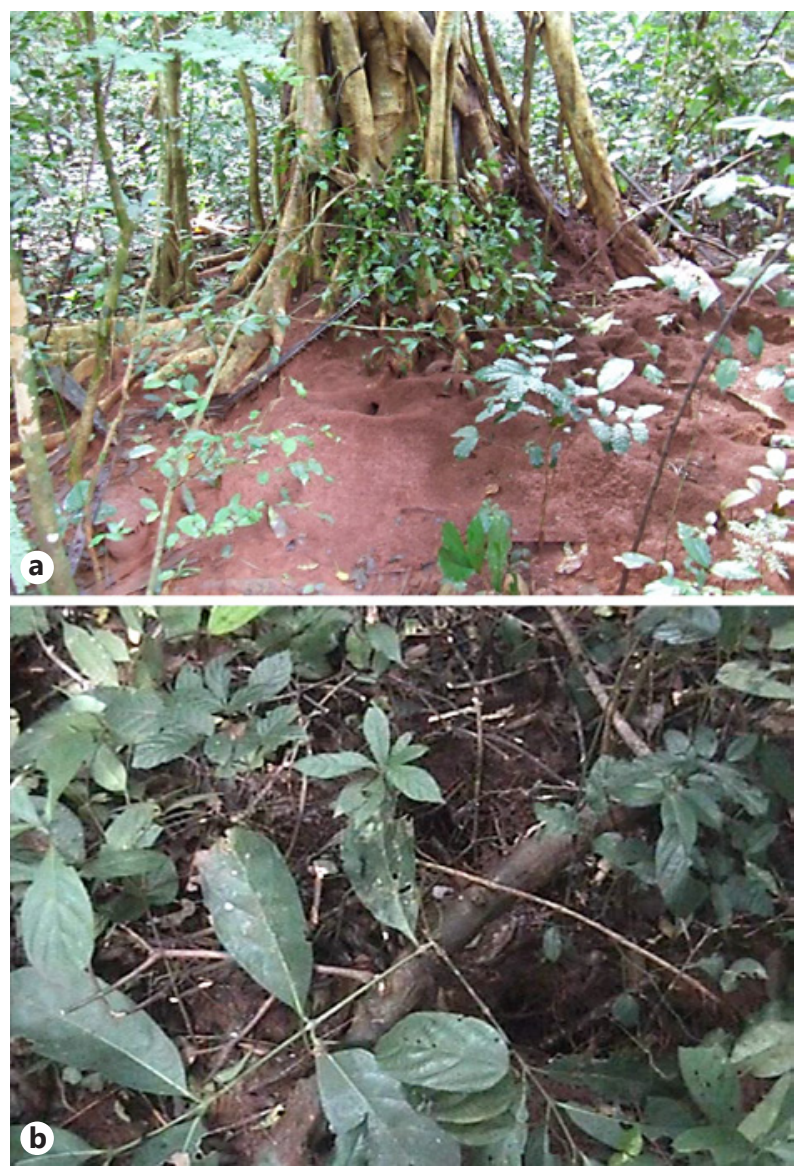




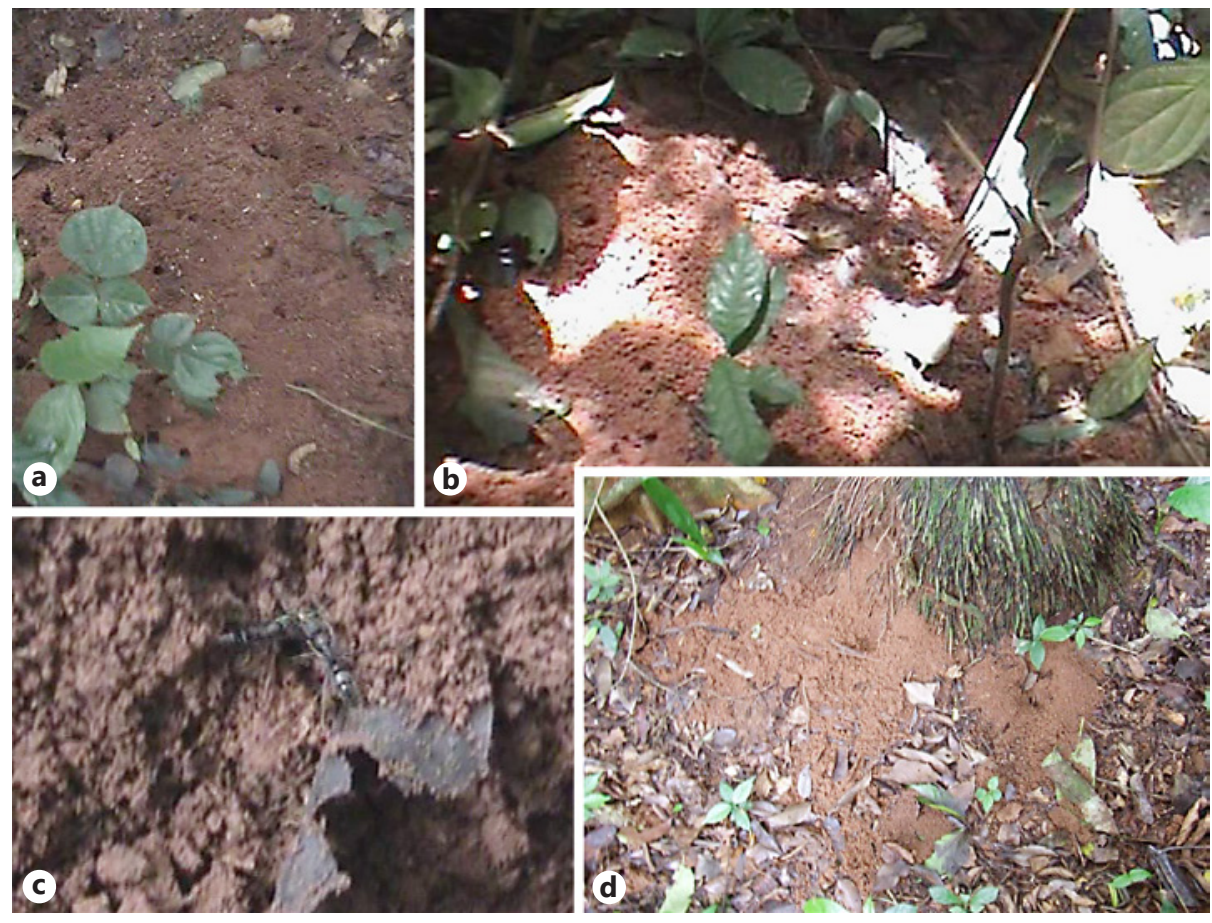

Fig. A2. Ponerine ant nests. a Mounds made by Paltothyreus tarsatus at Gangu, June 2005. The mounds (multiple hills punctured by a number of small holes, spread out across an approx. $50-\mathrm{m}^{2}$ area) looked nearly identical to those found at 2 chimpanzee tool sites at Gangu North in May 2005, at which ponerine ants were present. b Nests made by Megaponera analis at a tool site at Lebo, South Uele (September 2006). Like the P. tarsatus nests described above, these hills punctured by a number of small holes were spread over an approximately $50-\mathrm{m}^{2}$ area (sample identified by C. Schöning). c Ants, probably Paltothyreus tarsatus, filmed at a ponerine nest/chimpanzee tool site in May 2005. d A simpler ponerine nest with only one hill and one major hole at a chimpanzee "scoop site" found at Bambesa in March 2008. Large black ponerine ants were present at the site. According to the local assistant these were pupé (Megaponera analis), although this was not confirmed by an expert. The majority of ponerine ant nests we found resembled this one. 

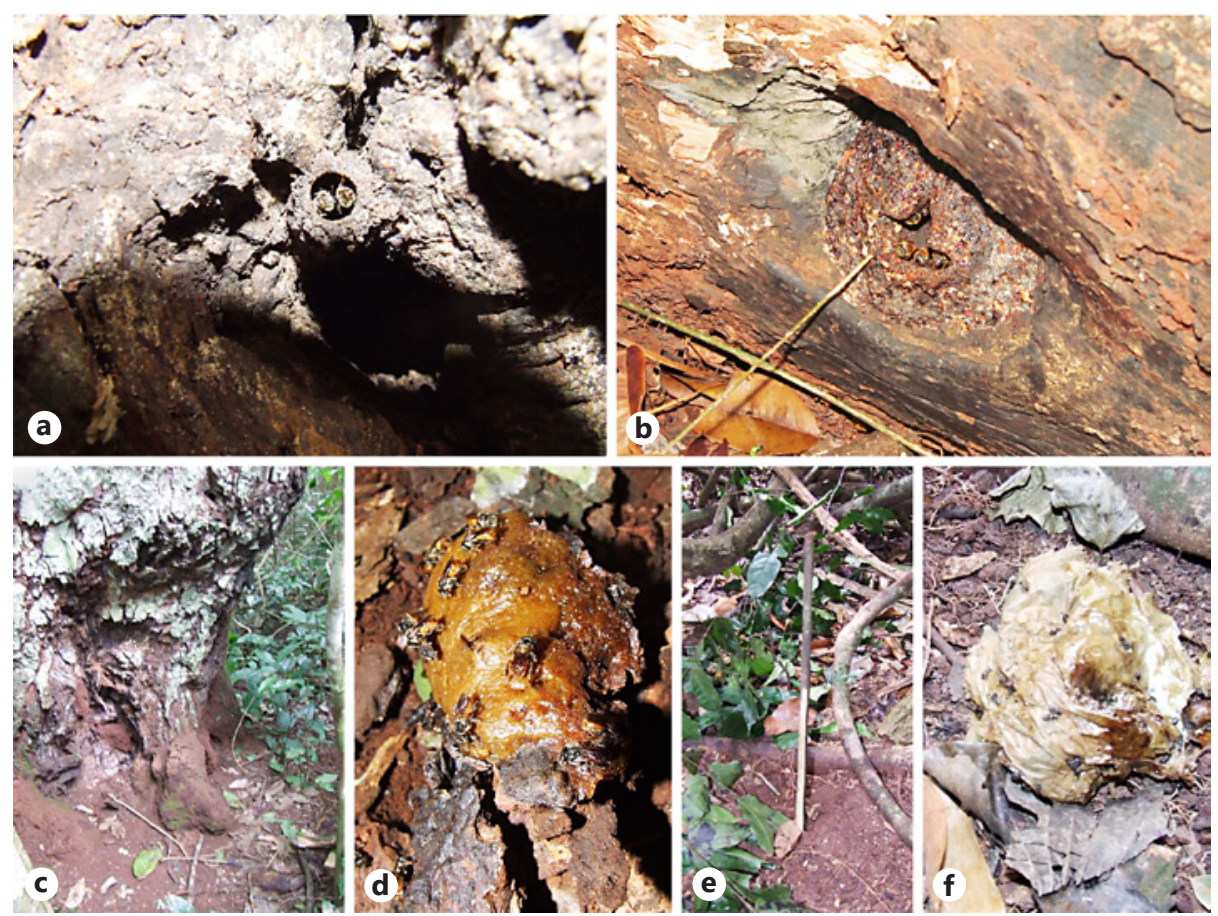

Fig. A3. a Arboreal meliponine bee nest at a chimpanzee tool site in Camp Louis savanna woodland, September 2006 (sample identified by David Roubik). b Arboreal meliponine bee nest at a tool site in Gangu North Forest, February 2013. c A honey tool site found in September 2006 (see a) with honeycomb and bees (Meliponula (Axestotrigona) ferruginea) (d), extracted by field assistants using a machete (sample identified by D. Roubik). e Terrestrial meliponine honey tool site at Gangu North, February 2016, with honeycomb and bees (Meliplebeia lendliana) (f) extracted by field assistants using a machete (sample identified by D. Roubik). 

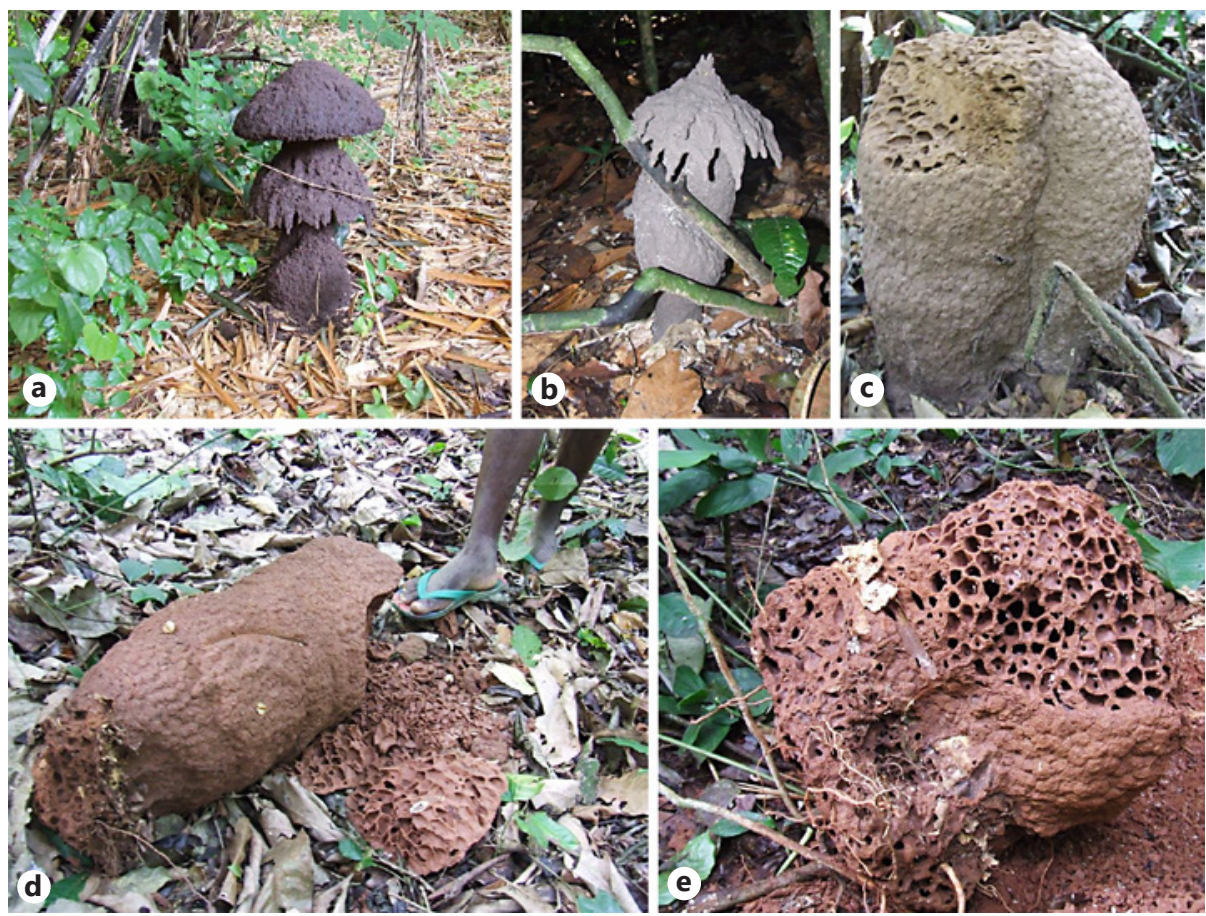

Fig. A4. a Cubitermes (species unknown) mound in the Bili South region, North Uele, 2006. b Cubitermes (species unknown) mound in the Buta region, South Uele, 2008. c Thoracotermes macrothorax mound in the Mbange East region, South Uele, January 2008 (sample identified by J. Darlington). d, e Thoracotermes macrothorax mounds in the Leguga Forest, South Uele, March 2008 (mounds of the same type found nearby were identified to the species by J. Darlington). 
Fig. A5. Main photo: An awaya termite mound (Macrotermes sp.) in the Bambesa Forest. J. Darlington identified these insects as Macrotermes muelleri from samples collected at another South Uele site, Mbange East. Inset M. muelleri specimens (local name: awaya) photographed in 2005 from a swarm in the Gangu Forest. The local field assistants often gathered these insects by hand and ate them raw. These insects react to disturbances by banging their heads against leaves, making a characteristic rattling sound.

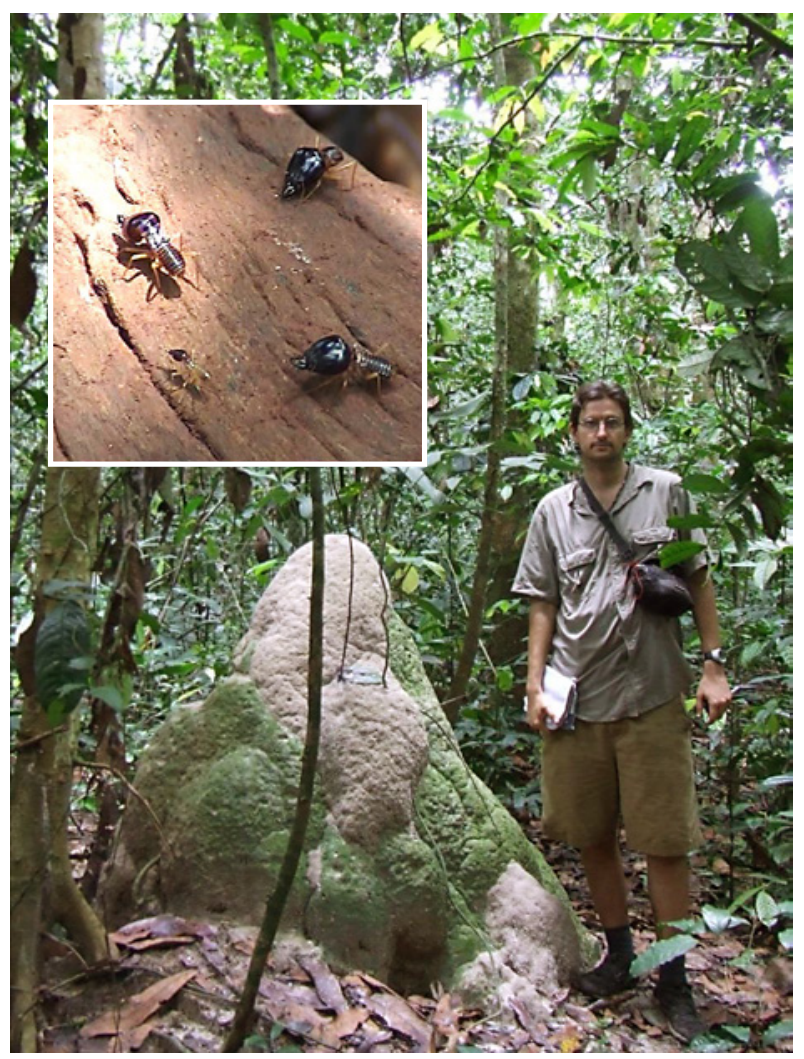


Fig. A6. An African giant snail (identified from other survey regions as Achatina schweinfurthi by B. Van Bocxlaer) climbing a tree at Leguga, South Uele, in 2008.

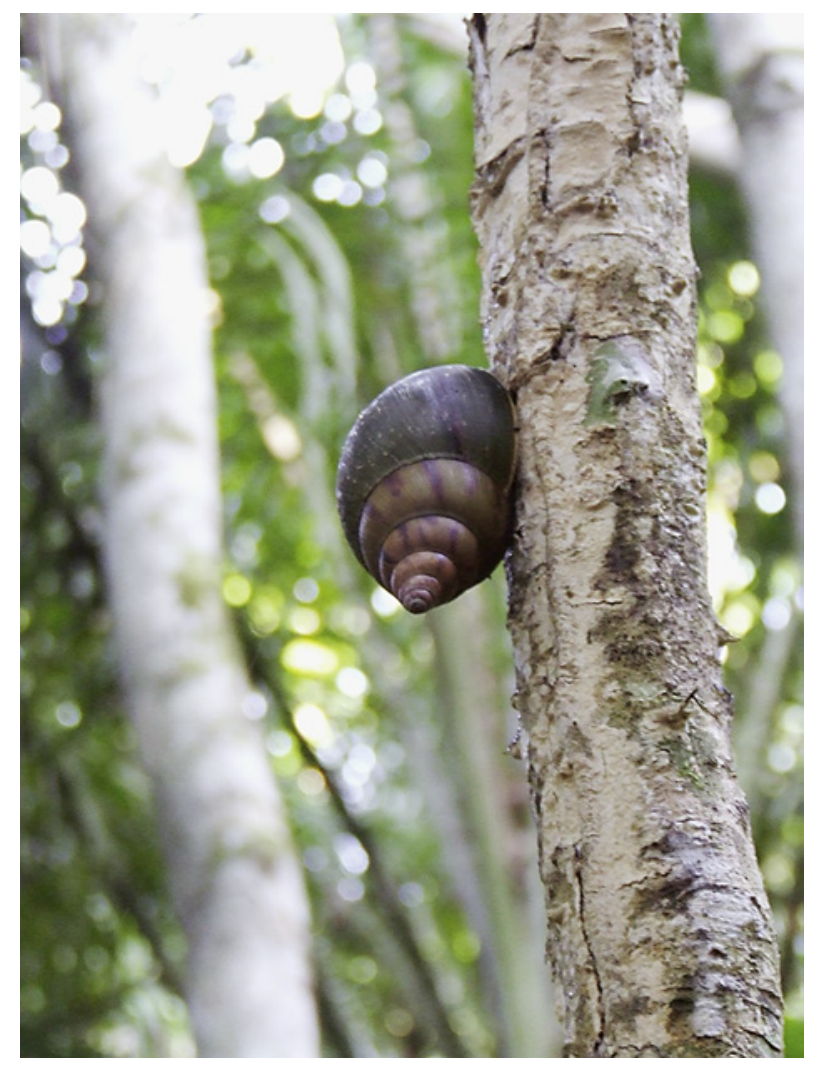




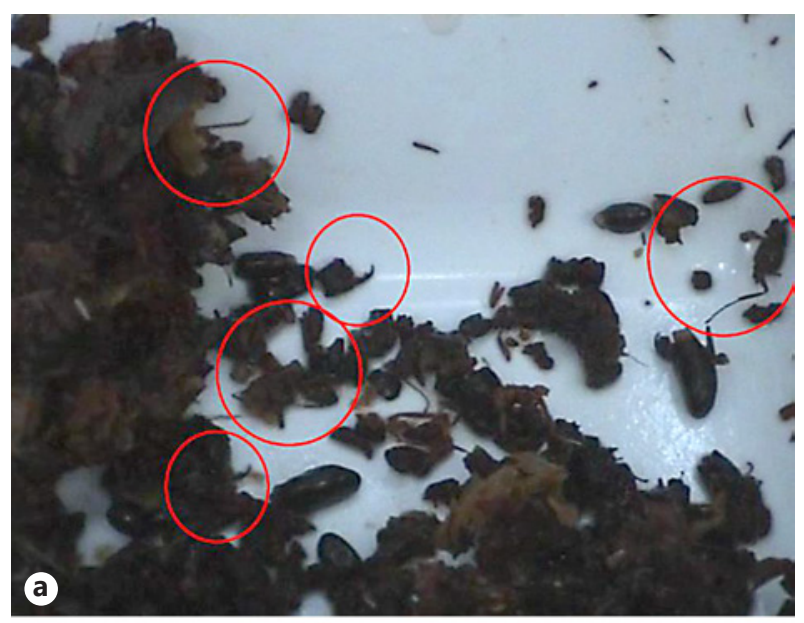

Fig. A7. a Epigaeic driver ant parts (surrounded by red circles), showcasing their large and powerful mandibles, found in chimpanzee dung in the Camp Louis region, November 2004. b Dorylus kohli ants found in chimpanzee dung at Akuma, South Uele, July 2008 (identified by C. Schöning).

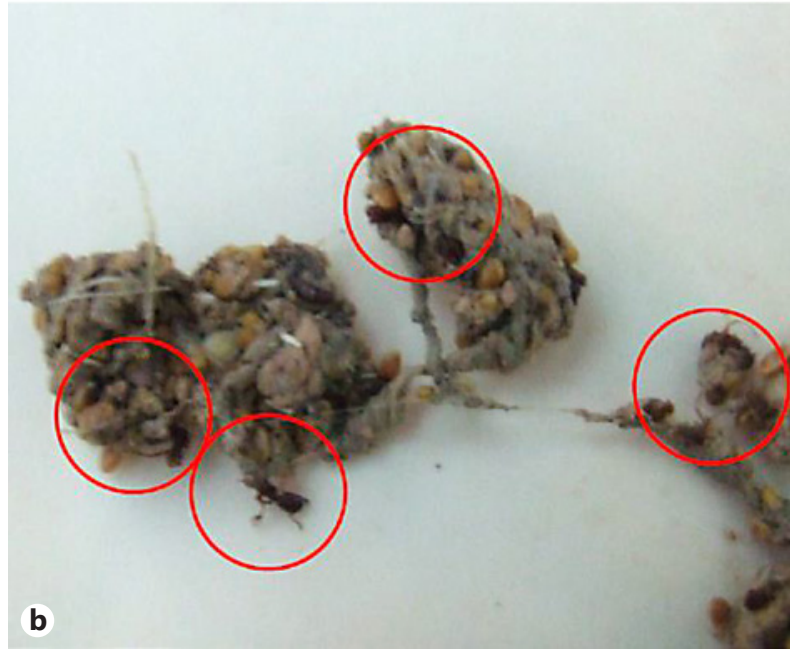



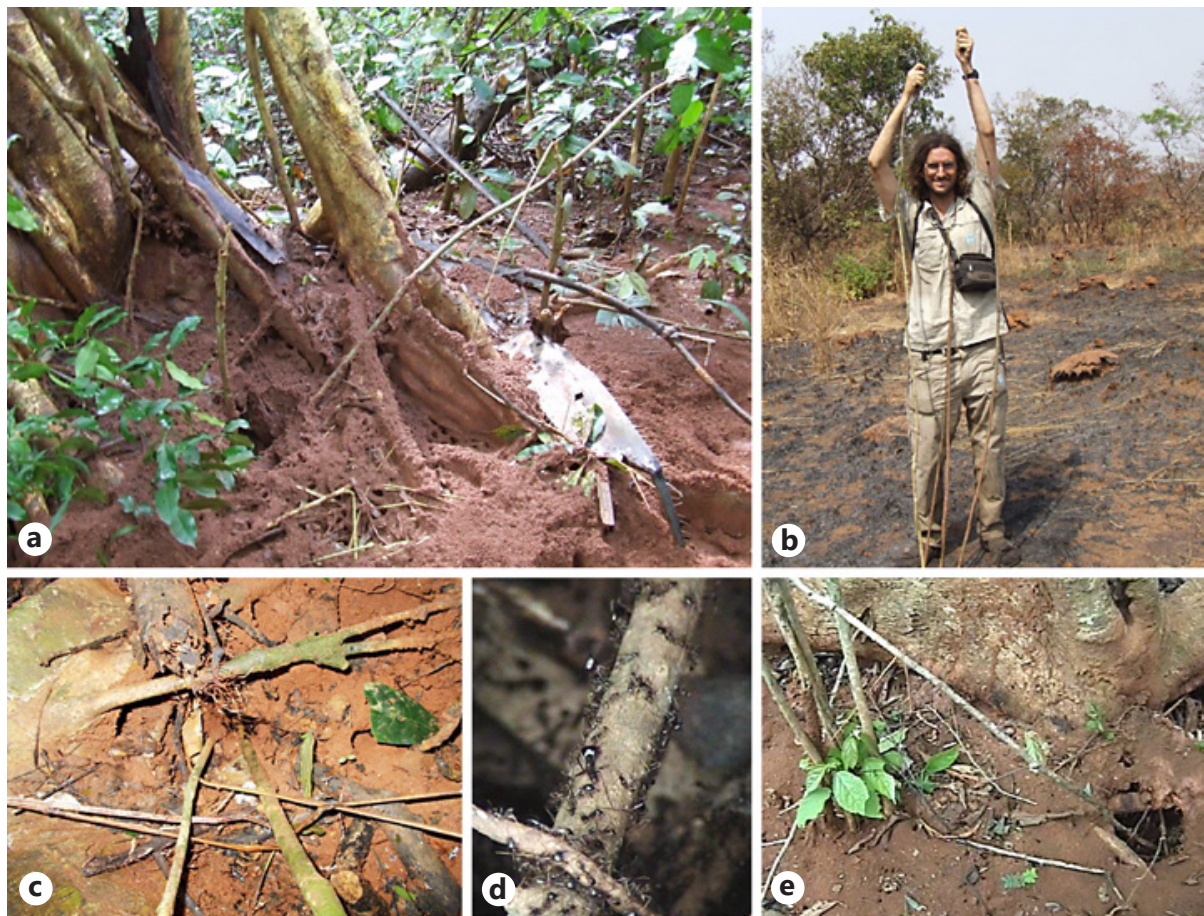

Fig. A8. Epigaeic Dorylus long probes. a D. wilverthi probing site, Camp Louis savanna edge forest (Ngulumbi), August 25, 2006. b The first author (2.1 m tall) with the longest epigaeic Dorylus tools documented in this study (approaching $2.5 \mathrm{~m}$ ), found in the forest near savanna at Zapay, December 29, 2006. c Epigaeic Dorylus ants attacking a chimpanzee tool found in the Bambillo Forest, October 2012 (photograph by Bebe Bofenda). d, e Epigaeic Dorylus ants swarm up a tool found on the savanna edge, Camp Louis region, April 2005. 

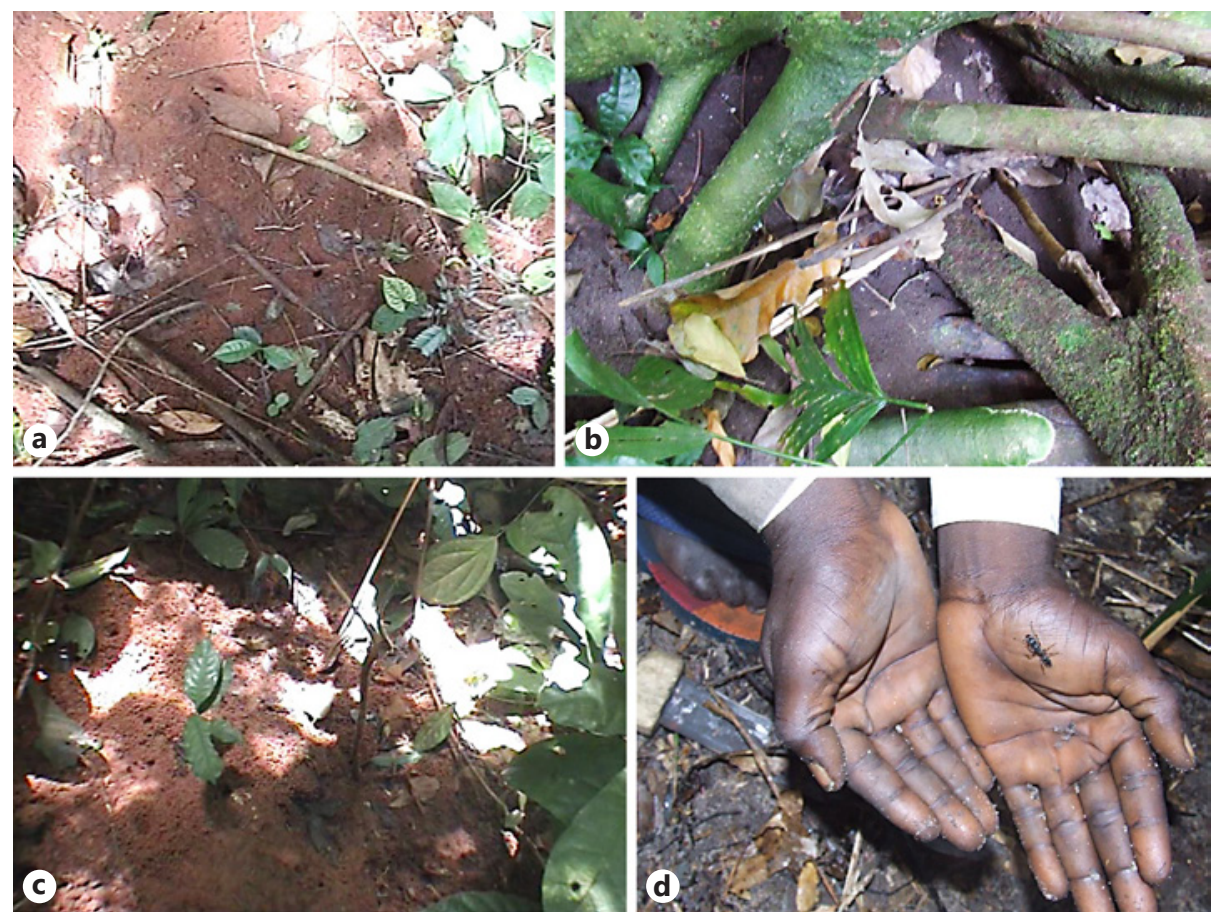

Fig. A9. Ponerine ant dip sites. a Gangu North Forest, May 2005. b Zapay, December 2006. A ponerine ant (probably Megaponera analis) was seen emerging from the ant nest. c Lebo Forest, South Uele, September 2006 (photograph by J. Swinkels). d A ponerine ant encountered at a nest exploited by tools in the Buta Forest, September 2008.

Fig. A10. Honey tree probes (a) and the bees targeted (b). Gangu North Forest, February 2013.
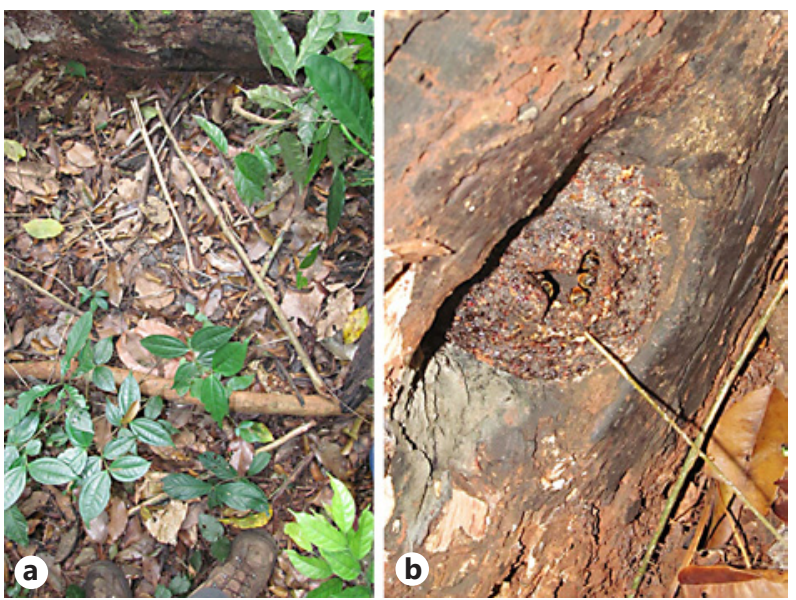


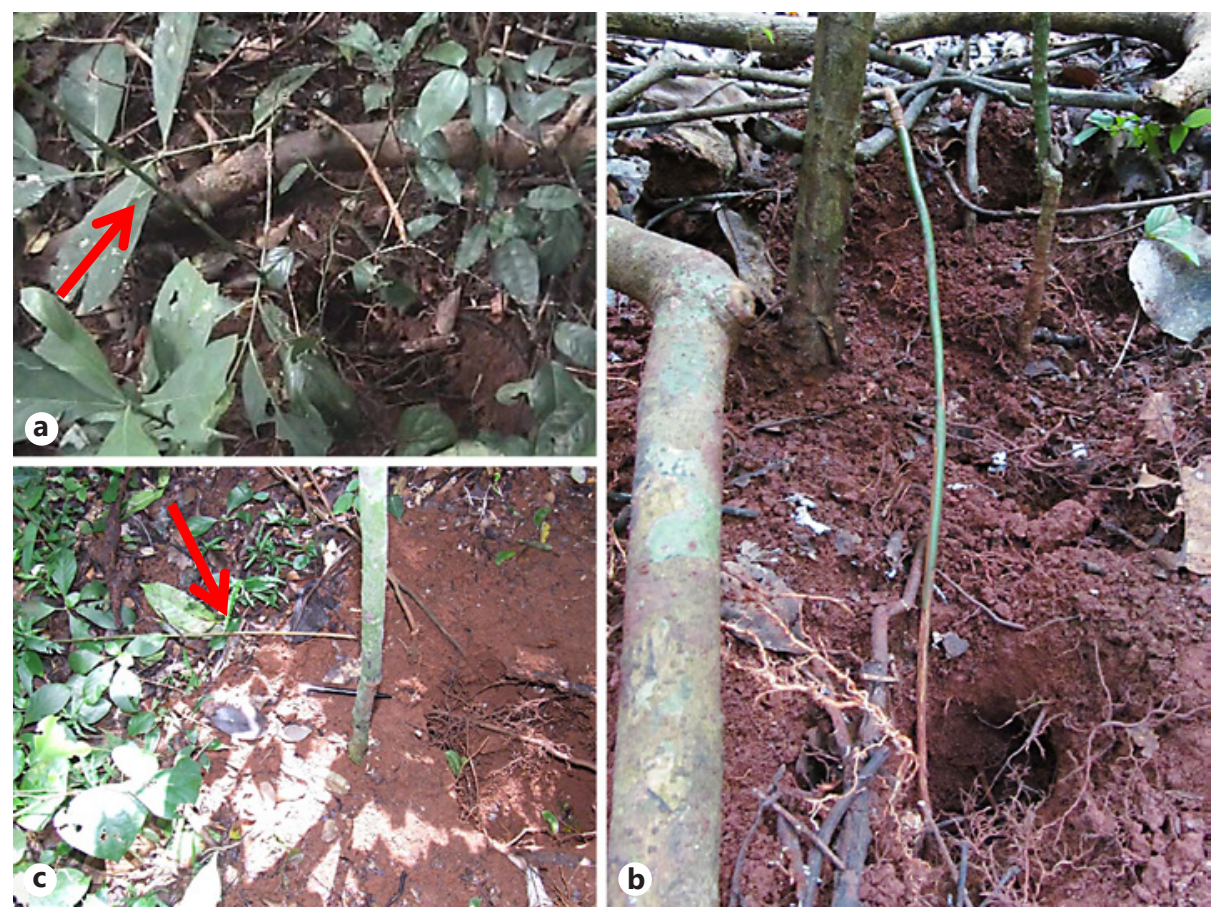

Fig. A11. Tools associated with Dorylus kohli sites. a The arrow indicates an ant dip tool used by a chimpanzee to prey on D. kohli in the Gangu South Forest in June 2005. b An assigned D. kohli tool, Gangu North, August 2012. c The arrow indicates a tool found in the Gangu North Forest in August 2012. 


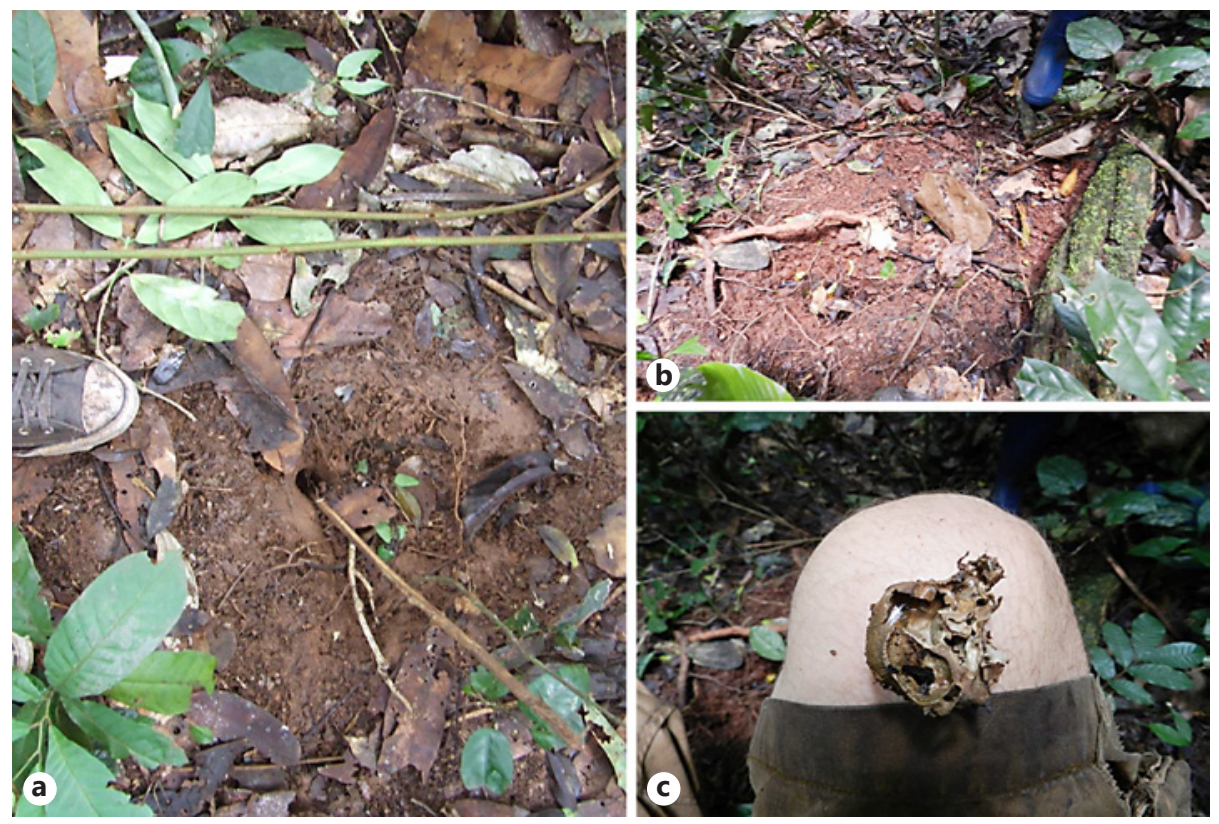

Fig. A12. a Honey excavation site, Gangu North Forest, August 2012. b, c Tools and extracted stingless bee comb from an underground nest in the Camp Louis region, September 2012. 
Fig. A13. a The newly described "ant scoop" tool in situ (bottom right) at an active Megaponera analis ant nest. We found a clear chimpanzee footprint embedded in the dirt on the nest. $\mathbf{b}$ The chimpanzee had broken off the ant scoop from a nearby branch.

Fig. A14. A crushed weaver ant (Oecophylla longinoda) nest found in association with chimpanzee evidence in the Gangu North Forest, January 2007.

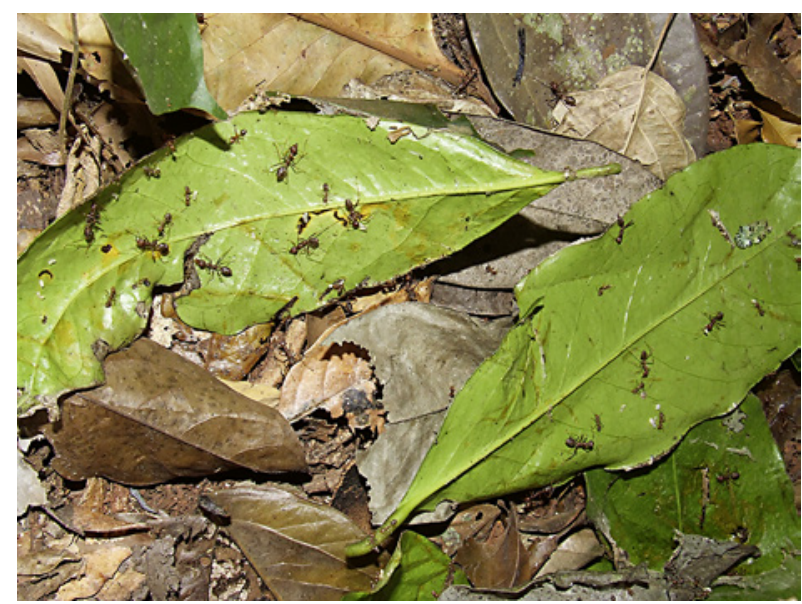

The Bili-Uéré Chimpanzee Behavioural Realm

Folia Primatol 2019;90:3-64 DOI: $10.1159 / 000492998$ 

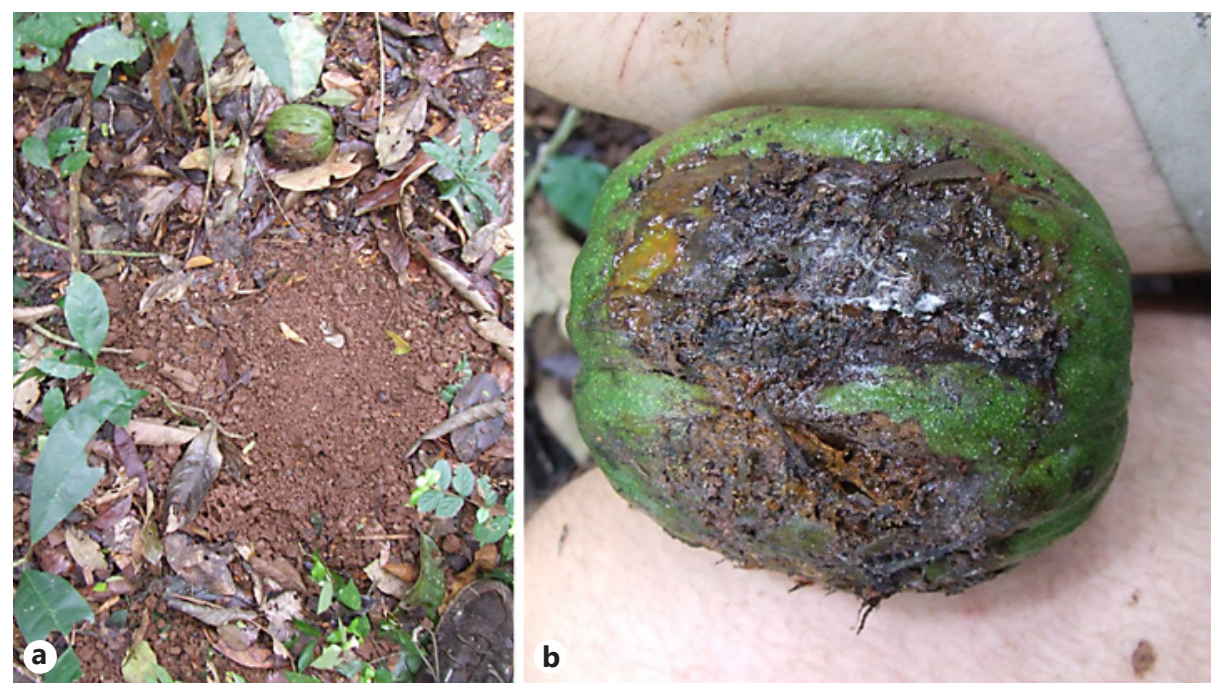

Fig. A15. a, b A Desplatsia dewevrei fruit which had apparently been used to hammer open a termite mound at a large chimpanzee "workshop" at Leguga.
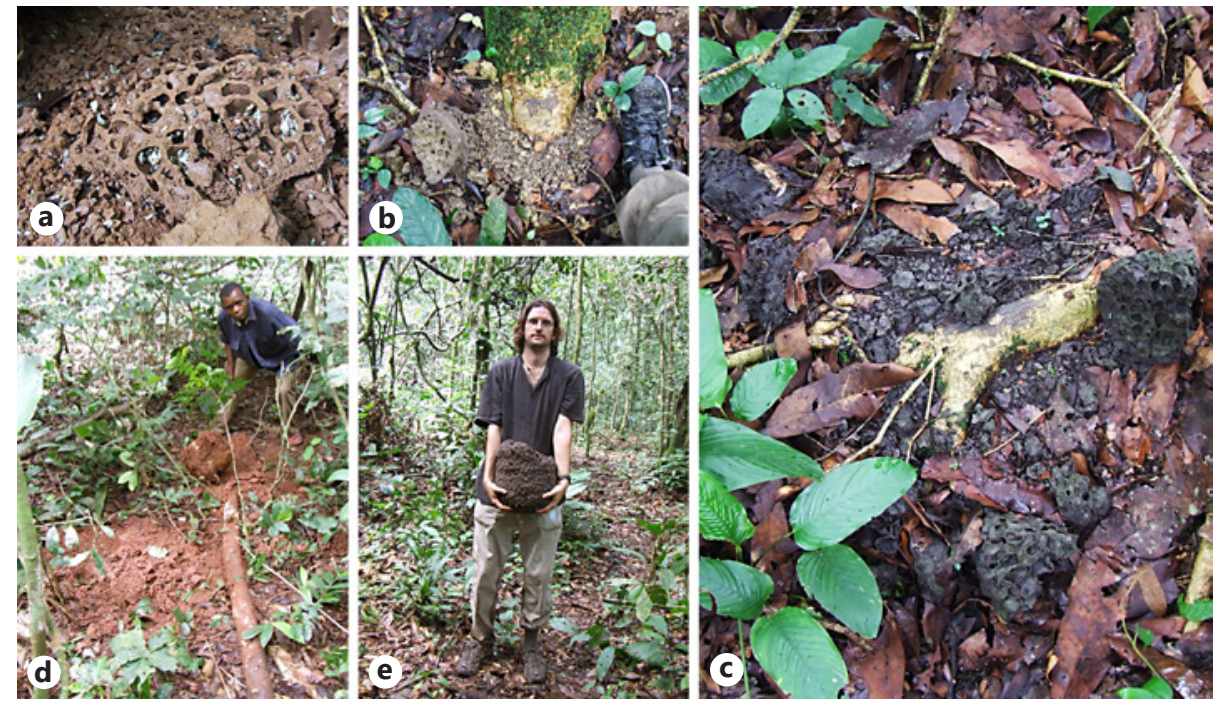

Fig. A16. a Thoracotermes macrothorax workers and winged alates in a mound just pounded open by a chimpanzee in the Leguga Forest, south of the Uele River. b, $\mathbf{c}$ Two termite mound-pounding sites separated by $183 \mathrm{~km}$ and on opposite sides of the Uele River: Lingo Forest, South Uele, probably Cubitermes (b), and Bili South Forest, North Uele, probably T. macrothorax (c). Each was smashed against a Gilbertiodendron dewevrei root. d K. Polycarpe with a freshly pounded T. macrothorax mound in the Leguga Forest, which we had just heard being pounded open by a chimpanzee against the log in the photograph. Chimpanzee faeces and termite larvae were found at the scene (photo a). e The chimpanzee that carried this termite mound (Thoracotermes, probably T. macrothorax) $3.6 \mathrm{~m}$ from its source to smash it on a root may have done so bipedally (South Bili Forest, 2006). 


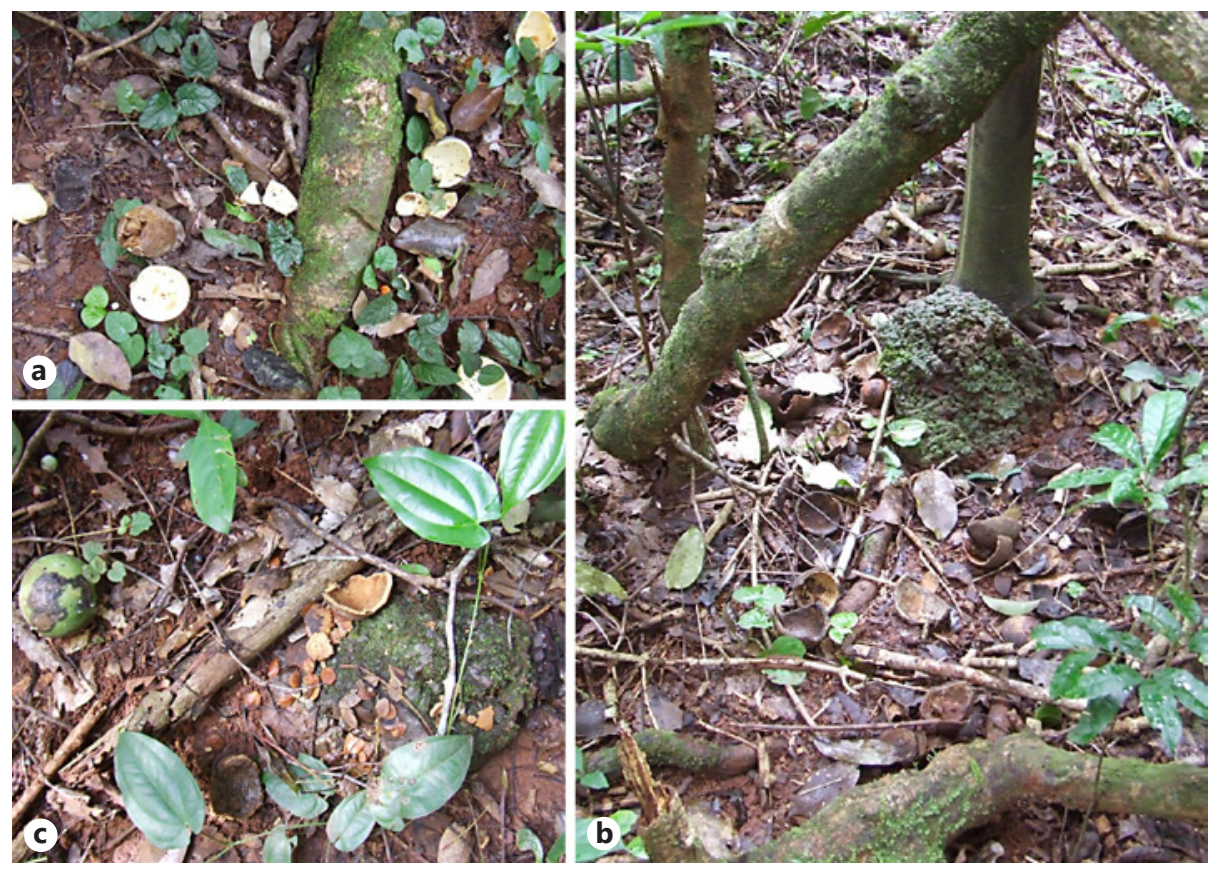

Fig. A17. a Fresh pounding site of a Strychnos fruit on a root, Gangu North Forest. b, c Two old Strychnos pounding sites on rocks, Gangu North. 


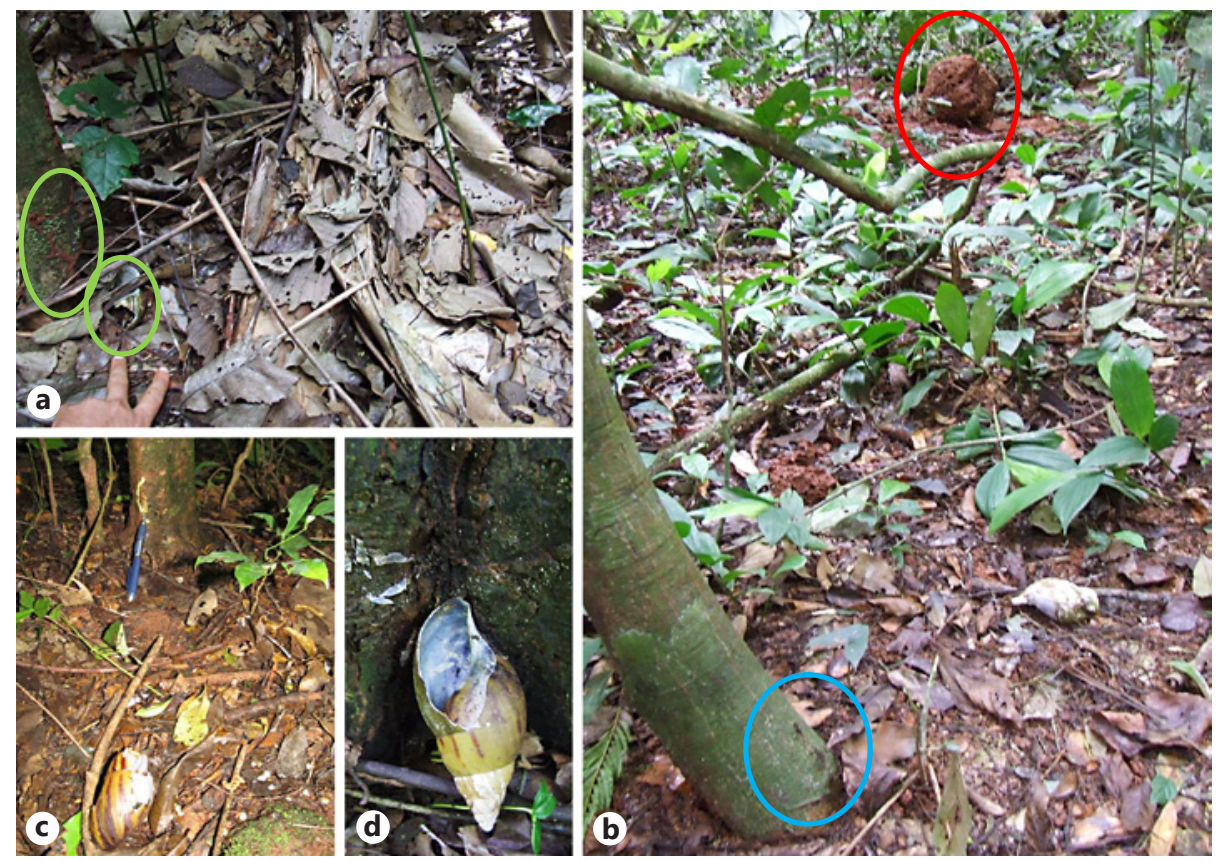

Fig. A18. a A pounded-open giant snail and the associated strike mark on a tree (both circled), within centimetres of a chimpanzee ground nest (the edge of the nest can be seen in the right half of the photograph), found in the Leguga Forest in March 2008. b A pounded-open snail within close proximity to a smashed termite mound (circle above), which we earlier heard the chimpanzee pounding open in the Leguga Forest. The strike mark on the tree is also circled. These were part of a "chimpanzee workshop," with nests, pounded termite mounds, snails and ground nests, found on March 19, 2008. c A pounded snail with eggs scattered across the ground in the Dume Forest, at the spot a chimpanzee had been sitting a couple of minutes earlier. Photograph by $\mathrm{H}$. Silegowa, August 2012. The strike mark is visible on the tree. $\mathbf{d}$ A pounded snail with fragments of the shell embedded in the tree, Bambesa 2008. 


\section{References}

Alp R (1997). "Stepping-sticks" and "seat-sticks": new types of tools used by wild chimpanzees (Pan troglodytes) in Sierra Leone. American Journal of Primatology 41: 45-52.

Baayen RH (2008). Analyzing Linguistic Data. Cambridge, Cambridge University Press.

Barr DJ, Levy R, Scheepers C, Tily HJ (2013). Random effects structure for confirmatory hypothesis testing: keep it maximal. Journal of Memory and Language 68: 255-278.

Boesch C (2012). Wild Cultures: A Comparison between Chimpanzee and Human Cultures. Cambridge, Cambridge University Press.

Boesch C, Boesch-Achermann H (2000). The Chimpanzees of the Taï Forest: Behavioral Ecology and Evolution. Oxford, Oxford University Press.

Boesch C, Boesch H (1990). Tool use and tool making in wild chimpanzees. Folia Primatologica 54: 86-99.

Boesch C, Head J, Robbins MM (2009). Complex tool sets for honey extraction among chimpanzees in Loango National Park, Gabon. Journal of Human Evolution 56: 560-569.

Boesch C, Kalan AK, Agbor A, Arandjelovic M, Dieguez P, Lapeyre V, Kühl HS (2016). Chimpanzees routinely fish for algae with tools during the dry season in Bakoun, Guinea. American Journal of Primatology DOI: 10.1002/ajp.22613.

Boesch C, Marchesi P, Marchesi N, Fruth B, Joulian F (1994). Is nut cracking in wild chimpanzees a cultural behaviour? Journal of Human Evolution 26: 325-338.

Bogart SL, Pruetz JD (2011). Insectivory of savanna chimpanzees (Pan troglodytes verus) at Fongoli, Senegal. American Journal of Physical Anthropology 145: 11-20.

Butynski TM (2001). Africa's great apes. In Great Apes and Humans: The Ethics of Coexistence (Beck BB, Stoinski TS, Hutchins M, Maple TL, Norton B, Rowan A, Stevens E, Arluke A, eds.), pp 3-56. Washington, Smithsonian Institution Press.

Campbell G, Kuehl H, Kouamé PNG, Boesch C (2008). Alarming decline of West Africa chimpanzees in Côte d'Ivoire. Current Biology 18: R903-R904.

Carvalho S, Biro D, McGrew WC, Matsuzawa T (2009). Tool-composite reuse in wild chimpanzees (Pan troglodytes): archaeologically invisible steps in the technological evolution of early hominins? Animal Cognition 12: 103-114.

Collard IF, Foley RA (2002). Latitudinal patterns and environmental determinants of recent human cultural diversity: do humans follow biogeographical rules? Evolutionary Ecology Research 4: 371-383.

Deblauwe I (2006). New evidence of honey-stick use by chimpanzees in southeast Cameroon. Pan African News 13: 2-4.

Deblauwe I (2009). Temporal variation in insect-eating by chimpanzees and gorillas in southeast Cameroon: extension of niche differentiation. International Journal of Primatology 30: 229-252.

d'Errico F, Backwell LR, Berger LR (2001). Bone tool use in termite foraging by early hominids and its impact on our understanding of early hominid behaviour. South African Journal of Science 97: 7175.

Dutton P, Chapman H (2015). New tools suggest local variation in tool use by a montane community of the rare Nigeria-Cameroon chimpanzee, Pan troglodytes ellioti, in Nigeria. Primates 56: 89-100.

Eggleton P (2000). Global patterns of termite diversity. In Termites: Evolution, Sociality, Symbioses, Ecology (Abe T, Bignell DE, Higashi M, eds.), pp 25-51. Dordrecht, Kluwer Academic Publishers.

Estienne V, Mundry R, Kühl HS, Boesch C (2017a). Exploitation of underground bee nests by three sympatric consumers in Loango National Park, Gabon. Biotropica 41:101-109.

Estienne V, Stephens C, Boesch C (2017b). Extraction of honey from underground bee nests by central African chimpanzees (Pan troglodytes troglodytes) in Loango National Park, Gabon: techniques and individual differences. American Journal of Primatology 79:e22672.

Fay J, Carroll R (1994). Chimpanzee tool use for honey and termite extraction in Central Africa. American Journal of Primatology 34:309-317.

Fowler A, Sommer V (2007). Subsistence technology of Nigerian chimpanzees. International Journal of Primatology 28: 997-1023.

Fünfstück T, Arandjelovic M, Morgan DB, Sanz C, Reed P, Olson SH, Cameron K, Ondzie A, Peeters M, Vigilant L (2015). The sampling scheme matters: Pan troglodytes troglodytes and P. t. schweinfurthii are characterized by clinal genetic variation rather than a strong subspecies break. American Journal of Physical Anthropology 156: 181-191.

Gagneux P, Gonder M, Goldberg T, Morin P (2001). Gene flow in wild chimpanzee populations: what genetic data tell us about chimpanzee movement over space and time. Philosophical Transactions of the Royal Society of London 356: 889-897.

Goodall J (1986). The Chimpanzees of Gombe: Patterns of Behavior. Cambridge, Belknap Press of Harvard University Press.

Harmand S, Lewis JE, Feibel CS, Lepre CJ, Prat S, Lenoble A, Boës X, Quinn RL, Brenet M, Arroyo A, Taylor N (2015). 3.3-million-year-old stone tools from Lomekwi 3, West Turkana, Kenya. Nature 521: 310-315.

The Bili-Uéré Chimpanzee Behavioural Realm

Folia Primatol 2019;90:3-64 
Hartigan JA, Hartigan PM (1985). The dip test of unimodality. Annals of Statistics 13: 70-84.

Hedges S, McGrew WC (2012). Ecological aspects of chimpanzee insectivory in the Budongo Forest, Uganda. Pan African News 19:6-7.

Hicks TC (2004). Chimpanzee (Pan troglodytes) Tool Use in the Ngotto Forest, Central African Republic. Master's thesis, Central Washington University.

Hicks TC (2010). A Chimpanzee Mega-Culture? Exploring Behavioral Continuity in Pan troglodytes schweinfurthii across Northern DR Congo. PhD thesis, University of Amsterdam.

Hicks TC (2014). Faunal diversity and human impact in two protected areas of northern DR Congo: BiliUére and Rubi-Télé. Lukuru Foundation, USFWS Final Report. http://www.bonoboincongo.com/ wp-content/uploads/2014/10/HicksUSFWSBiliFinalReport2014.pdf.

Hicks TC, Darby L, Hart J, Swinkels J, January N, Menken SBJ (2010). Trade in orphans and bushmeat threatens one of the Democratic Republic of the Congo's most important populations of eastern chimpanzees, Pan troglodytes schweinfurthii. African Primates 7: 1-18.

Hicks TC, Fouts RS, Fouts DH (2005). Chimpanzee (Pan troglodytes troglodytes) tool use in the Ngotto Forest, Central African Republic. American Journal of Primatology 65: 221-237.

Hicks TC, Tranquilli S, Kühl H, Campbell G, Swinkels J, Darby L, Boesch C, Hart J, Menken SBJ (2014). Absence of evidence is not evidence of absence: discovery of a large, continuous population of Pan troglodytes schweinfurthii in the Central Uele region of northern DRC. Biological Conservation 171: 107-113.

Hicks TC, Menken SBJ, Laudisoit A, Hart J (in press). Handling and consumption of vertebrate prey by chimpanzees (Pan troglodytes schweinfurthii) in Northern DR Congo. In Chimpanzees: Classification, Evolution and Behavior (Jensvold ML, ed.). Hauppauge, Nova.

Hirata S, Myowa M, Matsuzawa T (1998). Use of leaves as cushions to sit on wet ground by wild chimpanzees. American Journal of Primatology 44: 215-220.

Humle T, Matsuzawa T (2002). Ant-dipping among the chimpanzees of Bossou, Guinea, and some comparisons with other sites. American Journal of Primatology 58: 133-148.

Hunt KD, McGrew WC (2002). Chimpanzees in the dry habitats of Assirik, Senegal and Semilki Wildlife Reserve, Uganda. In Behavioural Diversity in Chimpanzees and Bonobos (Boesch C, Hohmann G, Marchant LF, eds.), pp 35-51. Cambridge, Cambridge University Press.

Koops K, McGrew WC, Matsuzawa T (2010). Do chimpanzees (Pan troglodytes) use cleavers and anvils to fracture Treculia africana fruits? Preliminary data on a new form of percussive technology. Primates 51: 175-178.

Koops K, McGrew WC, Matsuzawa T (2013). Ecology of culture: do environmental factors influence foraging tool use in wild chimpanzees, Pan troglodytes verus? Animal Behaviour 85: 175-185.

Koops K, Schöning C, Isaji M, Hashimoto C (2015). Cultural differences in ant-dipping tool length between neighbouring chimpanzee communities at Kalinzu, Uganda. Scientific Reports 5: 12456.

Koops K, Visalberghi E, van Schaik C (2014). The ecology of primate material culture. Biology Letters 10: 20140508

Kühl HS, Kalan AK, Arandjelovic M, Aubert F, D’Auvergne L, Goedmakers A, Jones S, Kehoe L, Regnaut S, Tickle A, Ton E, van Schijndel J, Abwe EE, Angedakin S, Agbor A, Ayimisin EA, Bailey E, Bessone M, Bonnet M, Brazolla G, Buh, V E, Chancellor R, Cipoletta C, Cohen H, Corogenes K, Coupland C, Curran B, Deschner T, Dierks K, Dieguez P, Dilambaka E, Diotoh O, Dowd D, Dunn A, Eshuis H, Fernandez R, Ginath Y, Hart J, Hedwig D, Ter Heegde M, Hicks T C, Imong I, Jeffery K J, Junker J, Kadam P, Kambi M, Kienast I, Kujirakwinja D, Langergraber K, Lapeyre V, Lapuente J, Lee K, Leinert V, Meier A, Maretti G, Marrocoli S, Mbi T J, Mihindou V, Moebius Y, Morgan D, Morgan B, Mulindahabi F, Murai M, Niyigabae P, Normand E, Ntare N, Ormsby L J, Piel A, Pruetz J, Rundus A, Sanz C, Sommer V, Stewart F, Tagg N, Vanleeuwe H, Vergnes V, Willie J, Wittig RM, Zuberbuehler K, Boesch C (2016). Chimpanzee accumulative stone throwing. Scientific Reports 6: 22219. DOI: $10.1038 /$ srep22219.

Kuroda S, Nishihara T, Suzuki S, Oko R (1996). Sympatric chimpanzees and gorillas in the Ndoki Forest, Congo. In Great Ape Societies (McGrew WC, Marchant LF, Nishida T, eds.), pp 71-81. Cambridge, Cambridge University Press.

Lapuente J, Hicks TC, Linsenmair KE (2016). Fluid dipping technology of chimpanzees in Comoé National Park, Ivory Coast. American Journal of Primatology 79: e22628. DOI: 10.1002/ajp.22628.

Langergraber K, Boesch C, Inoue E, Inoue-Murayama M, Mitani J, Nishida T, Pusey A, Reynolds V, Schubert G, Wrangham RW, Wroblewski E, Vigilant L (2010). Genetic and "cultural" similarity in wild chimpanzees. Proceedings of the Royal Society B: Biological Sciences 278: 408-416.

Lepre CJ, Roche H, Kent DV, Harmand S, Quinn RL, Brugal JP, Texier PJ, Lenoble A, Feibel CS (2011). An earlier origin for the Acheulian. Nature 477: 82-85.

Luncz LV, Boesch C (2015). The extent of cultural variation between adjacent chimpanzee (Pan troglodytes verus) communities: a microecological approach. American Journal of Physical Anthropology 156: $67-75$. 
Luncz LV, Proffitt T, Kulik L, Haslam M, Wittig RM (2016). Distance-decay effect in stone tool transport by wild chimpanzees. Proceedings of the Royal Society B 283: 20161607.

Luncz LV, Wittig RM, Boesch C (2015). Primate archaeology reveals cultural transmission in wild chimpanzees (Pan troglodytes verus). Philosophical Transactions of the Royal Society B 370: 20140348.

Marchant LF, McGrew WC (2005). Percussive technology: chimpanzee baobab smashing and the evolutionary modeling of hominid knapping. In Stone Knapping, the Necessary Conditions for a Uniquely Hominin Behaviour (Roux V, Bril B, eds.), McDonald Institute Monograph Series, pp 341-350. Cambridge, McDonald Institute.

McCullagh P, Nelder JA (1998). Generalized Linear Models. London, Chapman \& Hall.

McGrew WC (1974). Tool use by wild chimpanzees in feeding upon driver ants. Journal of Human Evolution 3: 501-508.

McGrew WC (1992). Chimpanzee Material Culture: Implications for Human Evolution. Cambridge, Cambridge University Press.

McGrew WC, Collins DA (1985). Tool use by wild chimpanzees (Pan troglodytes) to obtain termites (Macrotermes herus) in the Mahale Mountains, Tanzania. American Journal of Primatology 9: 47-62.

McGrew WC, Baldwin PJ, Tutin CEG (1988). Diet of wild chimpanzees (Pan troglodytes verus) at Mt. Assirik, Senegal. I. Composition. American Journal of Primatology 16: 213-226.

McGrew WC, Marchant LF, Beuerlein MM, Vrancken D, Fruth B, Hohmann G (2007). Prospects for bonobo insectivory: Lui Kotal, Democratic Republic of Congo. International Journal of Primatology 28:1237-1252.

McGrew WC, Marchant LF, Phillips CA (2009). Standardized protocol for primate faecal analysis. Primates 50: 363-366.

McGrew WC, Tutin CEG, Baldwin PJ (1979). Chimpanzees, tools, and termites: cross-cultural comparisons of Senegal, Tanzania, and Rio Muni. Man 14: 185-214.

McLennan MR (2011). Tool-use to obtain honey by chimpanzees at Bulindi: new record from Uganda. Primates 52: 315-322.

McLennan MR (2014). Chimpanzee insectivory in the northern half of Uganda's Rift Valley: do Bulindi chimpanzees conform to a regional pattern? Primates 55: 173-178.

McPherron SP, Alemseged Z, Marean CW, Wynn JG, Reed D, Geraads D, Bobe R, Béarat HA (2010). Evidence for stone-tool-assisted consumption of animal tissues before 3.39 million years ago at Dikika, Ethiopia. Nature 466: 857-860.

Mercader J, Panger M, Boesch C (2002). Excavation of a chimpanzee stone tool site in the African rainforest. Science 296: 1452-1455.

Möbius Y, Boesch C, Koops K, Matsuzawa T, Humle T (2008). Cultural differences in army ant predation by West African chimpanzees? A comparative study of microecological variables. Animal Behaviour 76: $37-45$.

Mundry R, Sommer C (2007). Discriminant function analysis with non-independent data: consequences and an alternative. Animal Behaviour 74: 965-976.

Newton-Fisher N (1999). Termite eating and food sharing by male chimpanzees in the Budongo Forest, Uganda. African Journal of Ecology 37: 369-371.

Nishida T, Uehara S (1983). Natural diet of chimpanzees (Pan troglodytes schweinfurthii): long-term record from the Mahale Mountains, Tanzania. African Study Monographs 3: 109-130.

O'Malley RC (2011). Environmental, Nutritional and Social Aspects of Insectivory by Gombe Chimpanzees. $\mathrm{PhD}$ thesis, University of Southern California, Los Angeles.

Pan African Programme (2016). The Cultured Chimpanzee. http://panafrican.eva.mpg.de.

Panger MA, Brooks AS, Richmond BG, Wood B (2002). Older than the Oldowan? Rethinking the emergence of hominin tool use. Evolutionary Anthropology: Issues, News, and Reviews 11: 235-245.

Pilsbry HA (1919). A review of the land mollusks of the Belgian Congo chiefly based on the collections of the American Museum Congo Expedition, 1909-1915. Bulletin of the American Museum of Natural History XL: 71.

Pruetz JD, Bertolani P (2007). Savanna chimpanzees, Pan troglodytes verus, hunt with tools. Current Biology 17: 412-417.

R Core Team (2014). R: A Language and Environment for Statistical Computing. Vienna, R Foundation for Statistical Computing.

Rolian C, Carvalho S (2017). Tool use and manufacture in the last common ancestor of Pan and Homo. In Chimpanzees and Human Evolution (Muller MN, Wrangham RW, Pilbeam DR, eds.), pp 602644. Cambridge, Belknap Press of Harvard University Press.

Sabater-Pi G (1984). Gorilas y chimpancés del Africa Occidental. México, Fondo de Cultura Economica.

Sanz CM, Morgan DB (2007). Chimpanzee tool technology in the Goualougo Triangle, Republic of Congo. Journal of Human Evolution 52: 420-433.

Sanz CM, Morgan DB (2009). Flexible and persistent tool-using strategies in honey-gathering by wild chimpanzees. International Journal of Primatology 30: 411-427. 
Sanz CM, Morgan DB, Gulick S (2004). New insights into chimpanzees, tools and termites from the Congo basin. American Naturalist 164: 567-581.

Sanz CM, Schöning C, Morgan DB (2010). Chimpanzees prey on army ants with specialized tool set. American Journal of Primatology 72: 17-24.

Schöning C, Humle T, Möbius Y, McGrew WC (2008). The nature of culture: technological variation in chimpanzee predation on army ants revisited. Journal of Human Evolution 55: 48-59.

Sept J (1992). Was there no place like home? A new perspective on early hominid archaeological sites from the mapping of chimpanzee nests. Current Anthropology 33: 187-207.

Struhsaker TT, Hunkeler P (1971). Evidence of tool-using by chimpanzees in the Ivory Coast. Folia Primatologica 15: 212-219.

Toth N, Schick K (2009). The Oldowan: the tool making of early hominins and chimpanzees compared. Annual Review of Anthropology 38: 289-305.

van Lawick-Goodall J (1968). The behaviour of free-living chimpanzees in the Gombe Stream Reserve. Animal Behaviour Monographs 1: 161-311.

van Schaik CP, Knott CD (2001). Geographic variation in tool use on Neesia fruits in orangutans. American Journal of Physical Anthropology 114: 331-342.

Vaidyanathan G (2011). The cultured chimpanzees. Nature 476: 266-269.

Venables WN, Ripley BD (2002). Modern Applied Statistics with S-PLUS, 4th ed. New York, Springer.

Walsh PD, Abernethy KA, Bermejo M, Beyers R, De Wachter P, Akou ME, Huijbregts B, Mambounga DI, Toham AK, Kilbourn AM, Lahm SA, Latour S, Maisels F, Mbina C, Mihindou Y, Obiang SN, Effa NE, Starkey MP, Telfer P, Thibault M, Tutin CEG, White LJT, Wilkie DS (2003). Catastrophic ape decline in western equatorial Africa. Nature 422: 611-614.

Whiten A, Goodall J, McGrew WC, Nishida T, Reynolds V, Sugiyama Y, Tutin CEG, Wrangham R, Boesch C (1999). Cultures in chimpanzees. Nature 399: 682-685.

Wrangham RW (2009). Catching Fire: How Cooking Made Us Human. New York, Basic Books.

Yamagiwa J, Yumoto T, Ndunda M, Maruhashi T (1988). Evidence of tool-use by chimpanzees (Pan troglodytes schweinfurthii) for digging out a bee-nest in the Kahuzi-Biega National Park, Zaire. Primates 29: 405-411. 